

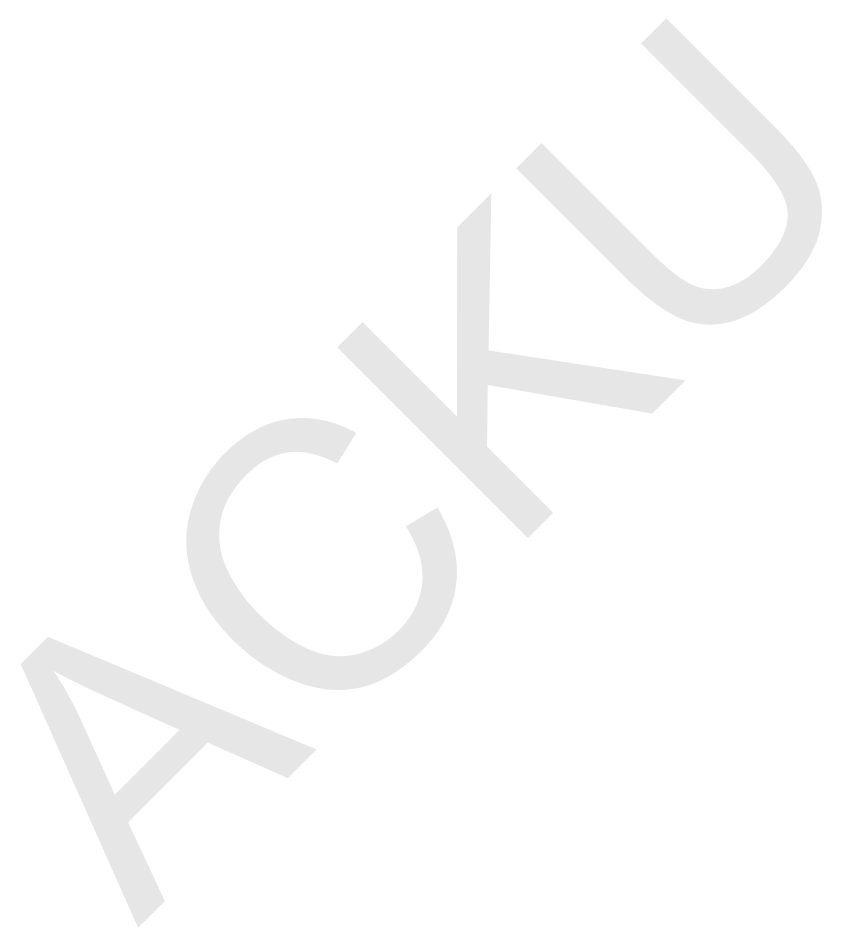




\section{Afghan people's attitudes and perceptions towards peace talks between the government and the Taliban}

Survey results in 15 provinces of Afghanistan

Kabul - March 2016

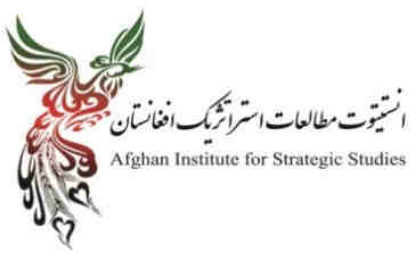




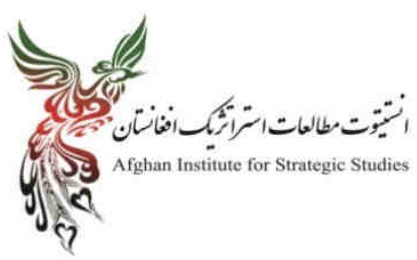

Afghan people's attitudes and perceptions towards peace talks between the government and the Taliban Authors: Ghulam Reza Ebrahimi \& Husain Ali Karimi Kabul - March 2016

Add: Qale 9 Borja, Karte Parwan, Kabul, Afghanistan www.aiss.af 
Table of Contents

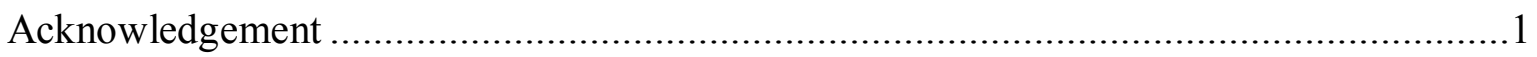

An introduction to Afghanistan Institute for Strategic Studies (AISS) ...............................

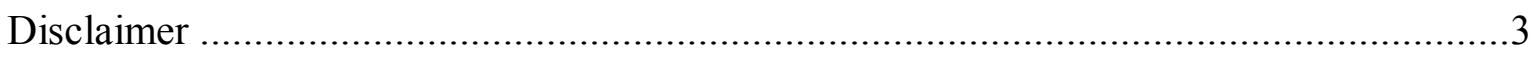

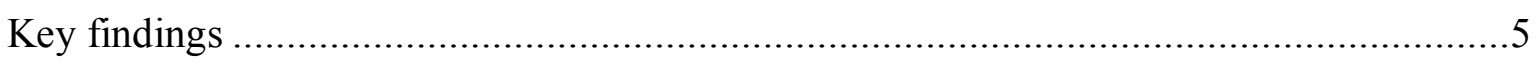

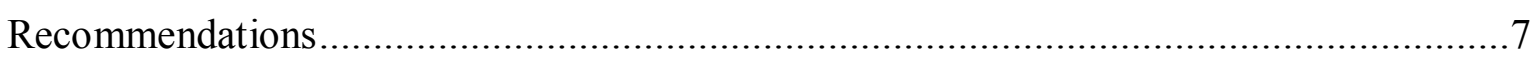

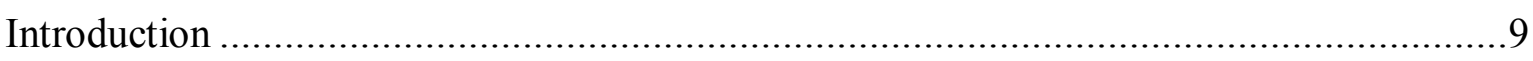

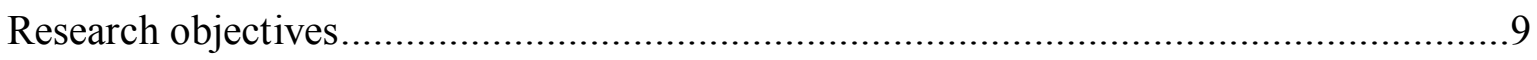

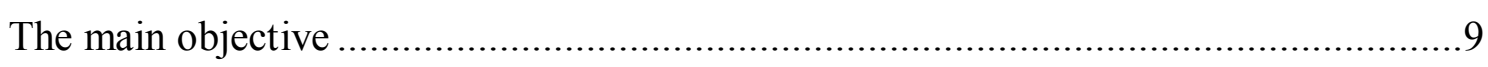

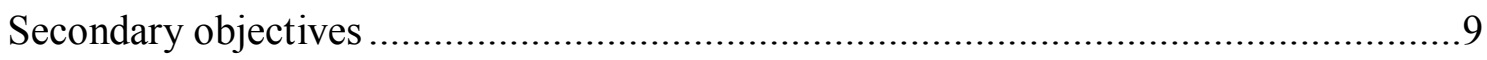

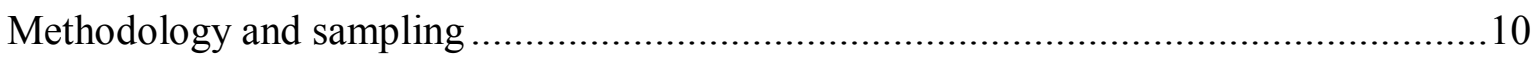

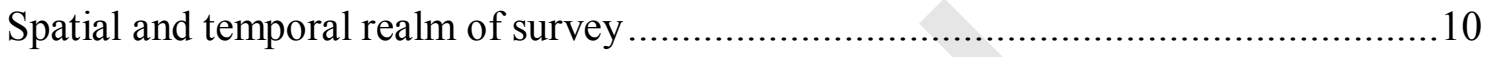

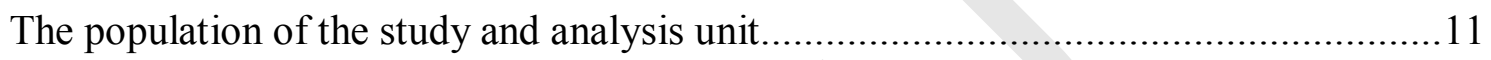

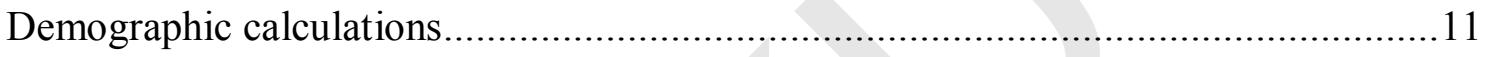

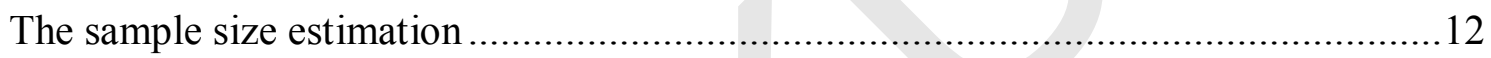

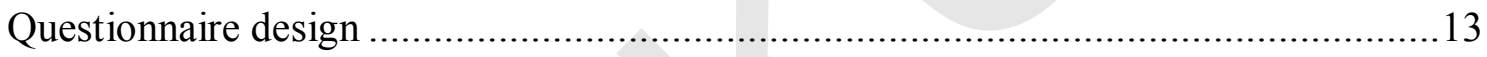

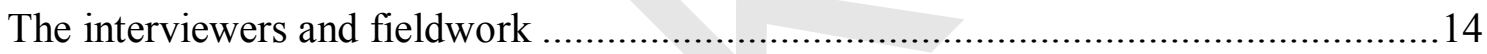

Process monitoring and quality control of the data collection stages.............................. 14

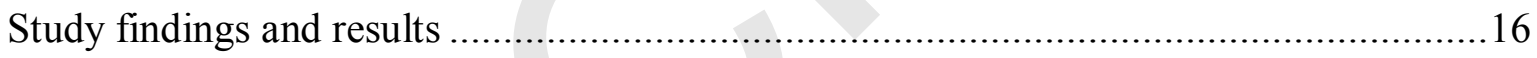

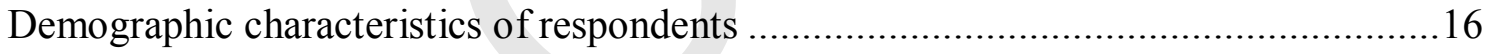

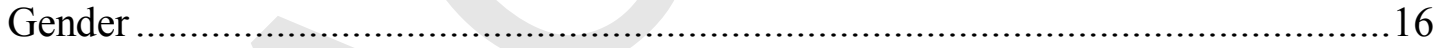

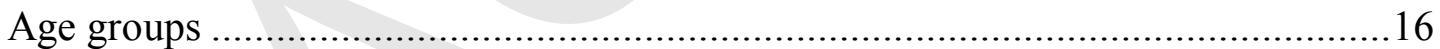

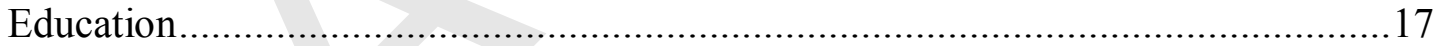

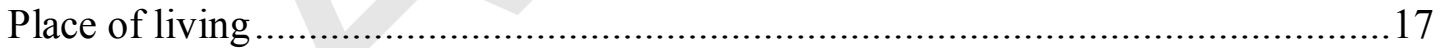

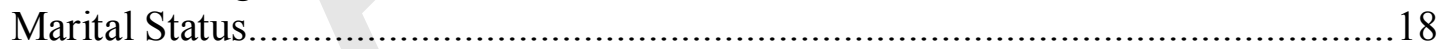

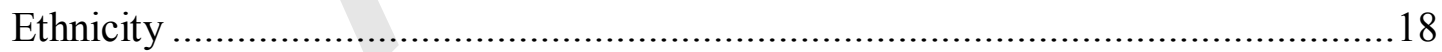

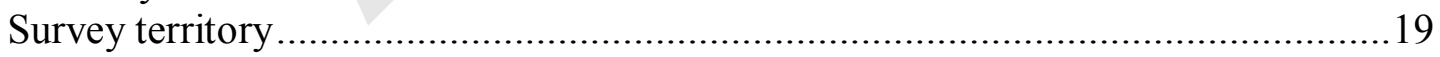

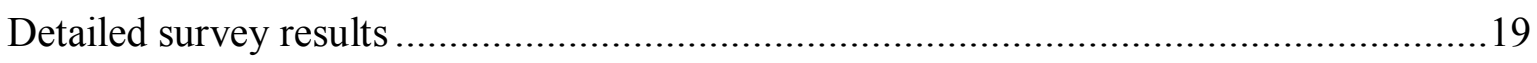

Feeling of safety in the place of living (town or village) ........................................ 19

Peace talks news follow up ............................................................................2 21

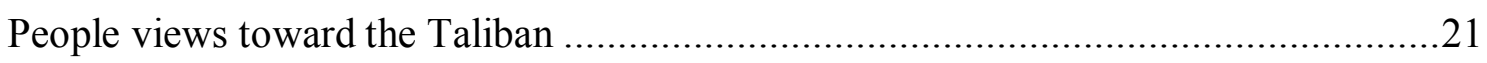

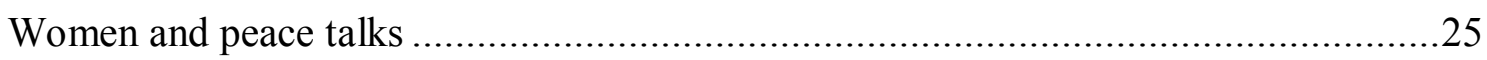

The respondents' viewpoints about the support and success of the peace talks .............28

Assessment of the process and results of peace talks...............................................29

Assessment of the obstacles and solutions to peace................................................... 34

Assessment of the forces affecting the success of peace talks .......................................... 36

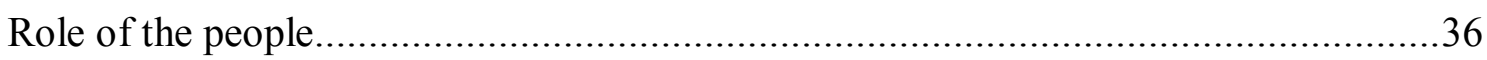


The impact of various local institutions and groups on peace talks ..............................36

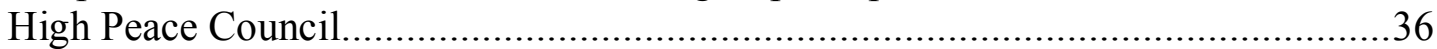

Government officials and consensus about peace talks with Taliban......................38

The role of various local institutions in the success of peace talks ..........................38

The impact of regional and international factors in the success of peace talks .............40

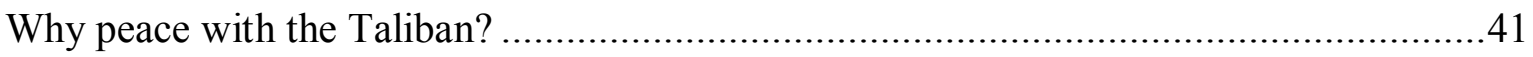

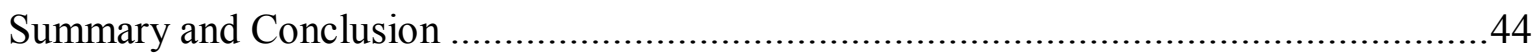

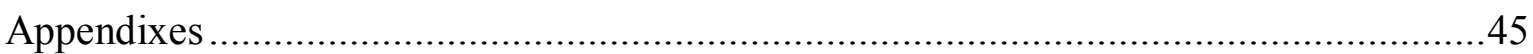

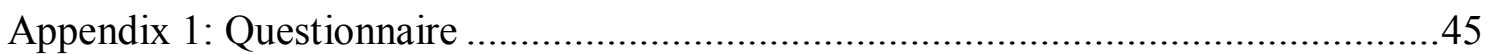

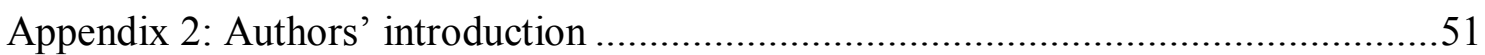




\section{Table of Charts}

Table 1: Percentage of the population over 18 disaggregated by the 15 provinces

Table 2: The preliminary and the final sample size

Table 3: The final sample size categorized by urban and rural.........................................13

Table 4: The success rate of the National Unity Government in peace talks.

\section{Table of Figures}

Figure 1: The respondent's gender by percentage.

Figure 2: the respondent's age group by percentage

Figure 3: the respondent's education levels by percentage

Figure 4: Respondents place of living by urban and rural

Figure 5: The respondent's marital status by percentage ............................................ 18

Figure 6: The respondent ethnicity by percentage ...................................................... 18

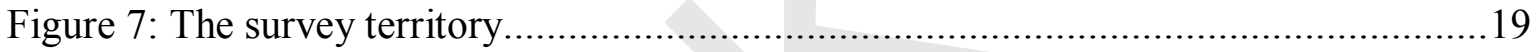

Figure 8: The respondents feeling of safety rate at their living place............................. 19

Figure 9: The respondents feeling of safety rate at their living place by province separation

Figure 10: The respondents feeling of safety rate at their living place by town/village

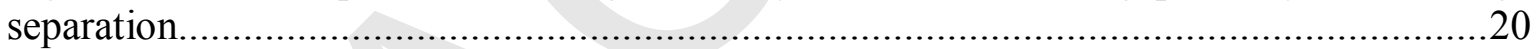

Figure 11: The rate of peace talks news follow up ......................................................21

Figure 12: The acceptability rate of the Taliban's actions ............................................21

Figure 13: The main reason of the Taliban for fighting the Afghan government ...............22

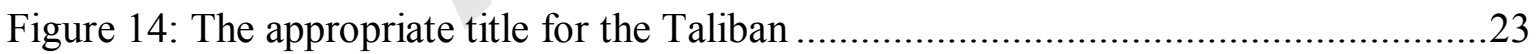

Figure 15: The appropriate title for the Taliban by rural/urban separation........................23

Figure 16: The appropriate title for the Taliban by gender separation .............................24

Figure 17: Taliban are part of Afghan society and it s important to share the power .........24

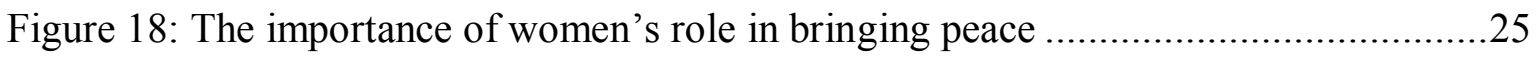

Figure 19: The importance of women's role in bringing peace by gender separation ........25

Figure 20: The effects of the government peace with the Taliban on the status of women.26

Figure 21: The effects of the government peace with the Taliban on the status of women by

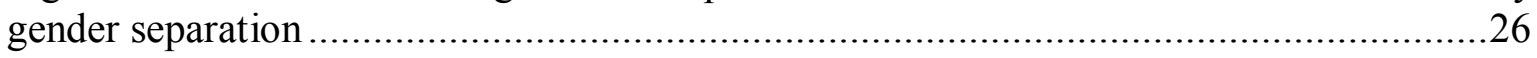

Figure 22: The effects of the government peace with the Taliban on the status of women by

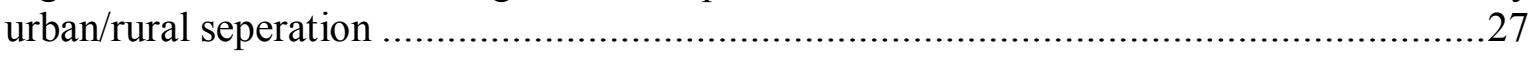

Figure 23: Women's rights are not important in the way to achieve peace......................27 
Figure 24: The supporting rate from the peace talks 28

Figure 25: The supporting rate from the peace talks by province separation .28

Figure 26: The evaluation of the government peace talks with the Taliban results since the beginning by province separation....

Figure 27: The success rate of the National Unity Government in peace talks by province separation.

Figure 28: The success rate of the National Unity Government in peace talks by ethnic separation.

Figure 29: The respondent's concerns about the peace talks

Figure 30: The success/failure rate of the plans to absorb armed oppositions into peace process.

Figure 31: The success/failure rate of the plans to absorb armed oppositions into peace

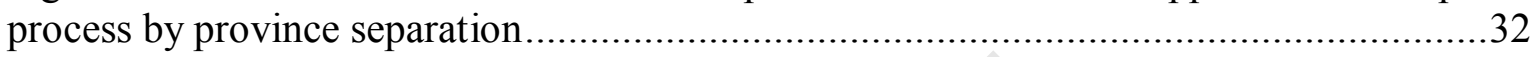

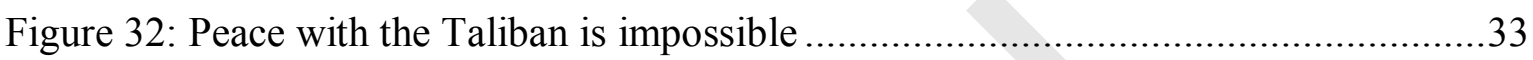

Figure 33: The best way to achieve peace and security is to fight the Taliban...................33

Figure 34: The biggest obstacles to bring peace in Afghanistan ..................................... 34

Figure 35: who benefits from war and insecurity in Afghanistan the most? ......................34

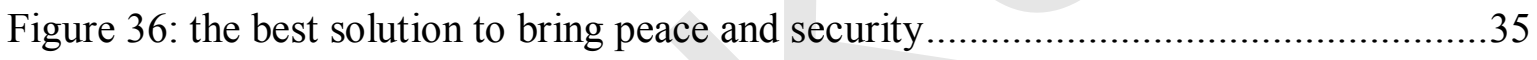

Figure 37: The effective factors on the failure of the government peace talks ...................35

Figure 38: The importance of people's role in bringing peace ........................................ 36

Figure 39: The High Peace Council defects ................................................................. 37

Figure 40: Expectation rate toward the future efforts of the High Peace Council in

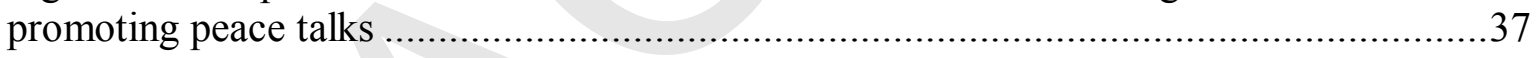

Figure 41: Government officials do not have a consensus about peace with the Taliban ...38

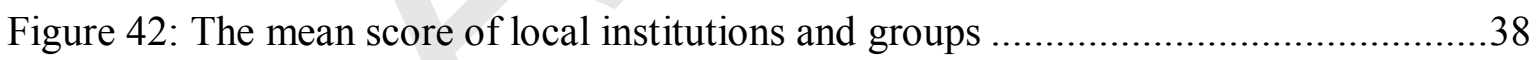

Figure 43: The average score of the local institutions and groups from perspective of urban respondents

Figure 44: The average score of the local institutions and groups from perspective of rural

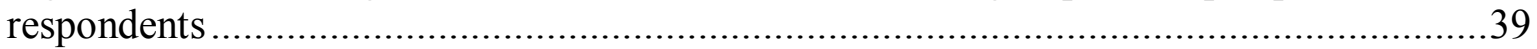

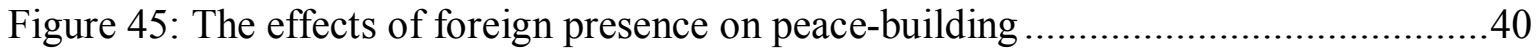

Figure 46: The Afghan government can promote peace talks without Pakistan's cooperation

Figure 47: The average score of the influence of some countries in the success of peace talks .....

Figure 48: The general perspectives of the respondents about the government peace with the Taliban 
The provinces covered by the survey

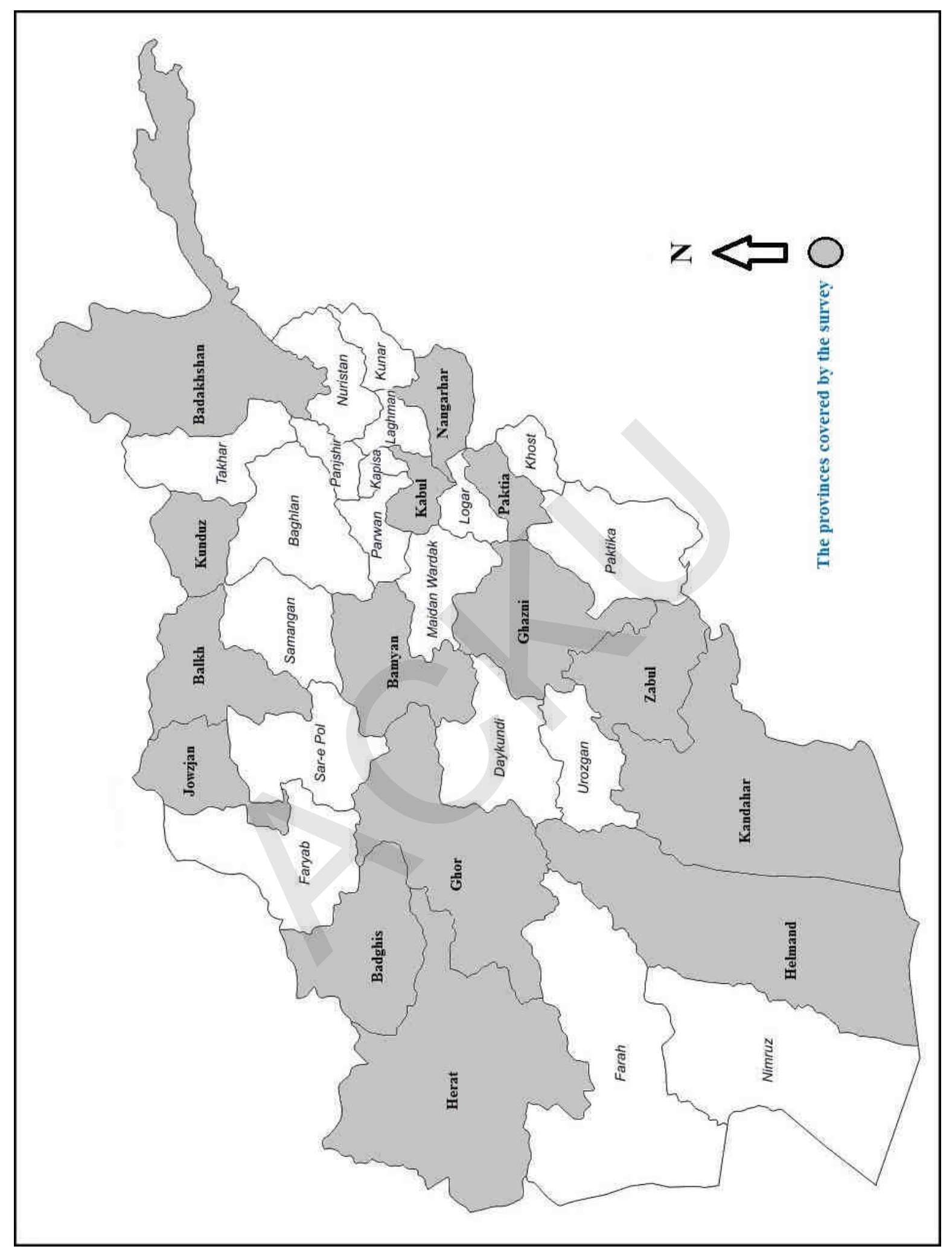




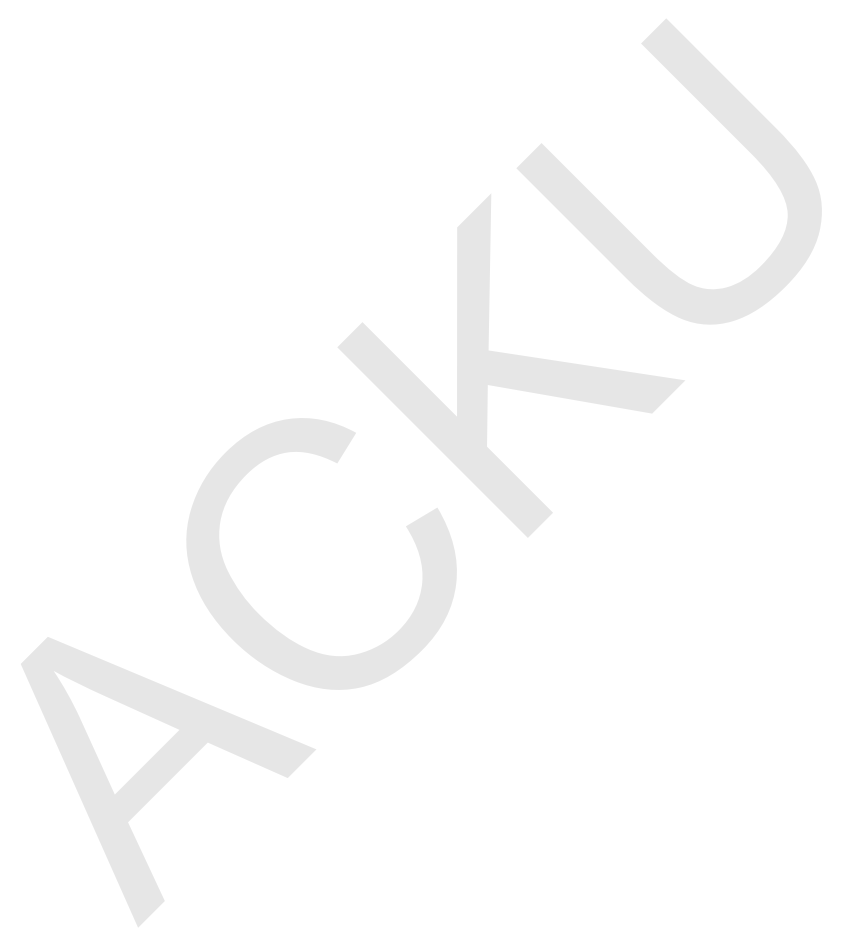




\section{Acknowledgement}

To conduct a successful research project, a constant teamwork is required. The authors of this report appreciate the work of all those who helped to accomplish different aspects of this research. We would like to express our gratitude and appreciations to:

- Dr. Rasoul Sadeghi: Professor at the faculty of social science, Tehran University (Advisor for the survey);

- Dr. Sardar Mohammad Rahimi: Professor at the Ibn-e-Sina University, and the Critical Literacy deputy at the Ministry of Education (Survey peer);

- Dr. Zalmai Nishat: Researcher at the Asia Centre of the University of Sussex;

We are also thankful to our colleagues:

- Mohammad Erfani: Fellow researcher at Afghan Institute for Strategic Studies;

- Reza Mohammadi: Fellow researcher at Afghan Institute for Strategic Studies, and the head of Afghan Writers Corporation;

- Abdul Ahad Mohammadi, Fellow researcher at the Afghan Institute for Strategic Studies

We would also like to thank Mr. Mohibullah Faghiri and Mr. Omid Zamani, managers of the Financial and Administrative departments of the institute, for their all-time support and efforts. And we are also immensely grateful to all our field interviewers. Without their genuine and sincere efforts and perseverance, accomplishment of this research project was impossible. 


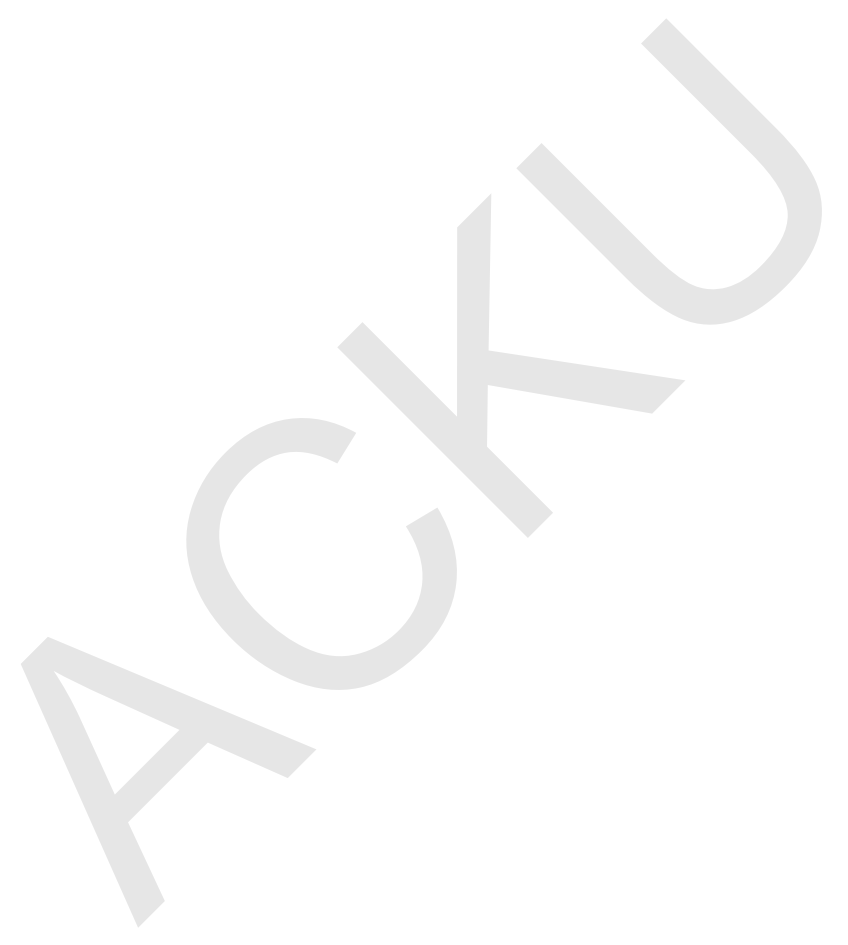




\section{An introduction to Afghanistan Institute for Strategic Studies (AISS)}

Afghan Institute for Strategic Studies (AISS) is an independent research institute. Its researches and studies focus on strategic issues. This institute has been established in October 2012 and it aimed at creating an intellectual space for addressing strategic issues pertaining to Afghanistan in the wider regional and international contexts. In order to take part in improvement and growth of democr acy, security, peace, good governance, etc. in the society, AISS is dedicated to conduct independent researches, translation and publication of scientific and academic books and articles, and to hold national and international seminars and conferences.

\section{Disclaimer!}

The content of this research does not represent the views of the Afghan Institute of Strategic Studies (AISS) or of the donor (NED). 


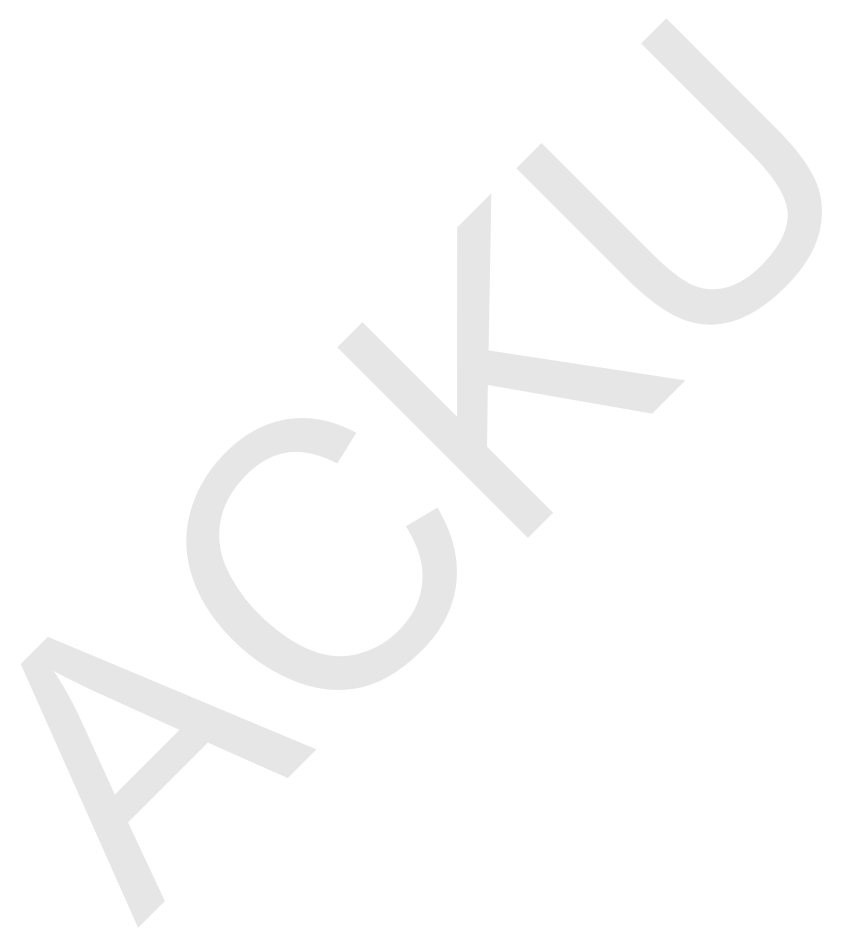




\section{Key findings}

* According to the results of the research $70.6 \%$ of respondents believe that government peace talks with the Taliban have been "failed". Besides $21.5 \%$ of them believe that it has been "partly successful".

* The respondents (1,540 people) believe that the amount of the success of the National Unity Government to establish peace is $28.61 \%$.

* The major concerns of the respondents about government's reconciliation with the Taliban are:

$>$ Compromising the rights of the people (25\%)

$>$ Failing to bring peace (20\%)

$>$ Lack of transparency in the peace process (19\%)

$>$ Ignoring the women's rights (14.3\%)

$>$ Disr egar ding the Constitution (13.7\%)

* From almost $68 \%$ of the respondents' point of view, "the plans to absorb the armed oppositions to the peace process" has been unsuccessful.

* The biggest obstacles to achieve peace in Afghanistan have been listed as:

$>$ Weak administration and widespread corruption (almost 34\%)

$>$ The Taliban (almost 20\%)

$>$ Nationalism and Tribalism (11.4\%)

$>$ Poverty and illiteracy of the people (11.2\%)

$>$ Local warlords and drug lords (8.2\%)

$>$ Presence of the for eign forces (almost 6\%)

* Approximately $48 \%$ of the respondents believe that "Pakistan and countries in the region" benefit the most from the war and insecurity in Afghanistan. "America and the West" with $20 \%$ and "corrupt government officials" with about $17 \%$ are the second and the third respectively.

* $33.6 \%$ of the respondents believe that the "interference of the neighboring and regional countries" is the main factor responsible for the failure of government's peace talk with the Taliban. Almost $31 \%$ of the respondents see "the weakness of the Afghan government" as the reason of the failure. About $14 \%$ of the respondents know "the interference of the America and the West" as the main cause of the failure. And $9.4 \%$ of the respondents pointed that the failure is because of "not including people in the peace talks".

* The most important weaknesses of the High Peace Council listed as:

$>$ Being a symbolic Council (19.9\%)

$>$ Corruption (16.4\%)

$>$ Lack of necessary independence and competence (16.2\%)

$>$ Lack of public support (14\%)

$>$ Foreign interference in its matters (11.4\%) 
* The Majority of the respondents (70.7\%) believe that "the government authorities do not have consensus about peace with the Taliban".

* Almost $86 \%$ of the respondents described the importance of the people's role in the peace process as "high" (54.4\%) and "very high" (31.4\%).

* Nearly $62 \%$ of respondents described the importance of the women's role in peace making "high" (34.5\%) and "very high" (27.3\%). Almost $28 \%$ of the respondents see the importance of the women's role "very little" (11\%) and "little" (17.4\%). And about $10 \%$ of the respondents believe that women's role in peace making "is not important".

* $60.2 \%$ of the respondents believe that after peace with the Taliban, "status of women will get worse". $10.8 \%$ of them think that "status of women will get better". $18.7 \%$ of the respondents believe that "status of women will not change".

* Almost $77 \%$ of the respondents believe that the Taliban actions "are unacceptable".

* Relatively majority of the respondents (28.4\%) see the main reason of the Taliban fighting as "assuring Pakistan's interests". $25.9 \%$ of the respondents believe that the Taliban are fighting for "power". About $13 \%$ thinks than they fight to "assure for eign countries' inter ests".

* $63.3 \%$ of the respondents considered it appropriate to call the Taliban as "enemy" (24.4\%), "terrorist" (19.9\%), and "mercenaries" (19\%). Only $1.8 \%$ of them were agreed to title the Taliban as "Mujahidin".

From respondents' point of view, Afghanistan's Ulema Council can have the greatest impact on the peace talks' success (3.4). The mass media like TV, radio and newspapers (3.38) and jihadi leaders and tribal elders (3.1) from respondents' perspective are at the second and third rank respectively. 


\section{Recommendations}

Given the importance of peace in a society and that peace is a fundamental need, also based on this survey results, the authors of this study offer the following suggestions in order to establish a desirable and sustainable peace:

1) To understand and emphasize on the importance of people's role in bringing peace

Any kinds of agreement on the matter should be supported by the people and they have the right to participate in national decision-making. Creating a desirable and sustainable peace is impossible without considering the will and wishes of the people. So the Afghan government should inform them about the process of peace talks with the Taliban. The government should take the concerns of all segments of the society into account. This is their right and should not be ignored for whatever reason.

\section{2) To understand and emphasize on the importance of women's role in bringing peace:}

One serious concern of the respondents in this survey was the status of women. Women constitute half of the population and this country cannot march towards a bright future without their participation. Their role and stand in the peace process should enhance.

3) To consider the regional and international actors' role in the peacebuilding in Afghanistan:

It is a fact that some countries in the region and around the world have defined interests in Afghanistan for themselves and believe they are right to be worried about their interests. The Afghan government must try to identify and understand these sensitive matters and concerns, so that they finally can align them with the inter ests of the Afghan people.

\section{4) To preserve the achievements of the past 14 years:}

One main concern of the people is to preserve the achievements of past years, such as the Constitution, freedom of expression, human rights, and women's rights and so on. In other word, these issues are the red line of the people for any negotiation with the Taliban. The Afghan government must be committed to protect these values in peace process.

\section{5) Transparency in the peace talks process:}

A sustainable and desirable peace is not possible if the process is shrouded in secrecy. If peace is to be achieved, any deal is going to be made, or any price is going to be paid, this is the right of the people to be aware of all the details. The wisdom of the people should be respected and the ground should be provided so that the 
people can be involved in the matter. Surely, any kind of negotiations which is not transpar ent will have no outcome other than political and social chaos.

\section{6) To reform the High Peace Council:}

It has been years since establishment of the High Peace Council as the official address of the government for peace negotiations. Despite all the efforts and spending that are made and although specific objectives were defined for it, but the High Peace Council has failed to meet people's expectations. There are serious doubts about the success of the programs to attract and absorb the armed oppositions to the peace process. If the Afghan government intends to continue peace talks from the same address, it should redefine the Council's legal status, restructure it, and give the required authority and independence to it.

\section{7) To use the capacity of Ulema in Afghanistan for peace-building:}

Afghan society is religious and traditional; so the religious leaders enjoy a valuable and influential social base among the people. Given that most of the violence that is exercised by armed group is partly regarded as divine and religious, they can have a fundamental role to sketch a correct picture of the conflict and create awareness among people in this regard. We need to use all the capacities of our society in order to bring peace. Surely, the use if this social capital will assist us in establishing durable peace.

\section{8) To use mass media in promoting peace:}

One of the most important functions of the media is to reflect the consequences and evils of the war and to portray goodness and aspects of life in peace and security. This is an approach that today the Afghan society greatly need. Media can help the society in peace-building process by strengthening the national values which are free from violence. So, keeping in view the important role of the mass media in changing public perceptions, thoughts and opinions, it should be used widely to promote peaceful coexistence.

\section{9) To empower Afghan armed forces:}

What is clear so far is that the government policy of tolerance has no other outcome than strengthening the Taliban. Continuation of this policy will put the military and other security forces of the country in a weak position. So, the Afghan government and its international partners should reexamine their approach. There should not be any kind of negligence about the ways we could empower the Afghan military and security institutions. The Taliban should be dealt with decisively, or otherwise, we will again see the repeat of the Kunduz incident. 


\section{Introduction}

Gaston Bouthoul (1974) in his book "Sociology of peace" calls security "the root of peace". He believes that to achieve a humane and supportive environment can encourage all our instinctive efforts. At the current situation what can be discussed as the most important social demand and necessity of Afghans is peace-building. For years the dark and evil shadow of war, violence and insecurity which have been the obstacle on the way to peace, have affected the different aspects of our social and political life.

It has been more than ten years that the series of efforts has started in order to bring peace to this war-torn country. But so far, neither of these efforts has been successful to pave the way for peace in Afghanistan.

The first official effort of Afghan government to seek peace was creating a "peace consolidation committee" in 2004 headed by Sibghatullah Mojaddedi. The idea of talks and negotiations with the Taliban had been repeatedly considered and discussed from the early years of Karzai's government; but the point which was unclear from the beginning was the framew ork of this dialogue. In late 2008, the plan for the dialogue between Afghan government and the Taliban brokered by Saudi Ar abia was revealed. This issue raised a lot of concerns and questions about the form and content of the negotiation with the Taliban in the society. Finally, in order to accelerate and legitimize the peace talks, a Loya Jirga was held in 2010 in Kabul. Later, the idea of negotiating with the Taliban was presented as a strategic outlook and the High Peace Council began its work as the official representative of the Afghan government to negotiate with the Taliban.

Following its researches and strategic studies on important strategic matters of Afghan society, Afghan Institute for Strategic Studies this time has picked out working on the crucial issue of peace in the country. The survey which was conducted in 15 provinces contains the impressions, views and assessment of people about the peace talks between the Afghan government and the Taliban.

\section{Research objectives}

\section{The main objective}

To analyze and examine the views and interpretation of people of Afghanistan towards the Afghan government peace talks with the Taliban in 15 provinces of the country including Kabul, Herat, Balkh, Kandahar, Bamyan, Badghis, Badakhshan, Ghazni, Nangar har, Jawzjan, Paktia, Helmand, Kunduz, Zabul and Ghor .

\section{Secondary objectives}

1. To examine the prospects of different social groups in relation to the 
peace and the government peace talks with the Taliban.

2. People's evaluation of the success of the peace talks with the Taliban

3. To review the role and place of women in the government peace talks with the Taliban.

4. To evaluate the main concerns of the people about the government peace talks with the Taliban.

5. To review the effective obstacles and factors on peacemaking.

6. To examine the attitudes and views of people towards the Taliban.

7. To evaluate the effectiveness of some domestic institutions and some for eign countries in the peace negotiations with the Taliban.

\section{Methodology and sampling}

This study which is a survey is a functional-descriptive strategic research that in terms of methodology, and a questionnaire was used to collect the information needed for the study. To analyze and examine the collected data, SPSS and EXCEL softwares were used. In this study, the analysis level is based on descriptive and inferential statistics.

The sampling method was based on multistage probability method. In the probability method, choosing samples and study units was random to make sure the sampling was by chance and there was equal possibility for all study units to be selected. One of the different kinds of the probability sampling is the multistage method which is used in this study. Also the distribution and number of the cases were based on the proportion of the population of the selected regions.

\section{Spatial and temporal realm of survey}

The survey was conducted in 15 provinces of Afghanistan including Kabul, Herat, Balkh, Kandahar, Bamyan, Badghis, Nangarhar, Badakhshan, Kunduz, Nangarhar, Jawzjan, Ghor, Zabul, Helmand and Paktia and Ghazni. Of these 15 provinces, 11 were randomly selected but four of them (Kabul, Herat, Balk and Kandahar) were not.

Due to growing insecurity in many provinces of the country, particularly in the provinces covered by this survey as well as increasing insecurity of roads between the districts of a province, this survey was implemented only in the provincial capitals of the mentioned provinces and two accessible districts which had no security issue for the field interviewers. These districts were selected after consultation with the regional interviewers who are residents of the same provinces. In some provinces where security-related problems were less, the selected number of the districts has reached three to four.

The survey began in the early October 2015 with the documentary and library 
studies, and was finished by the end of March 2016. After training field interviewers and finalizing the questionnaire, the next phase was to collect data from 15 provinces by the questionnaire which was designed by the researchers. This phase began in December 2015 and continued for one month.

\section{The population of the study and analysis unit}

The population and analysis unit of the study included all over 18-year old residents of the 15 provinces cover ed by the survey.

\section{Demographic calculations}

Total population of the country in 2015 was estimated about 28.6 million, including approximately 14.7 million men and 13.9 woman. Besides, $75.3 \%$ of the population is consisted of rural population and $24.7 \%$ of urban population ${ }^{1}$. The above mentioned approximate statistics shows that the majority of Afghanistan's population is rural.

Table 1: Percentage of the population over 18 disaggregated by the 15 provinces

\begin{tabular}{|c|c|c|}
\hline No & Province & Population over 18 (\%) \\
\hline 1 & Badakhshan & 50.22 \\
\hline 2 & Badghis & 51.1 \\
\hline 3 & Balkh & 48.8 \\
\hline 4 & Bamyan & 48.16 \\
\hline 6 & Ghazni & 48.36 \\
\hline 7 & Ghor & 50.89 \\
\hline 8 & Helmand & 46 \\
\hline 10 & Heart & 47.54 \\
\hline 11 & Jawzjan & 52.65 \\
\hline 12 & Kabul & 51.02 \\
\hline 13 & Kandahar & 45.89 \\
\hline 14 & Kunduz & 46.94 \\
\hline 15 & Nangarhar & 49.28 \\
\hline
\end{tabular}

To estimate the population over 18 in each province, the study has used the UN approximate statistics disaggregated by age groups ${ }^{2}$. Regarding the approximate statistics presented by the United Nation Statistics Division, the final estimation of

1. The approximate statistics is retrieved from:

http:/ / cso.gov.af/ fa/ page/ demography-and-socile-statistics/ demograph-statistics/ 3897111

2. The approximate statistics is retrieved from:

http:/ / esa.un.org/ unpd/ wpp/ Download/ Standard/ Population/ 
the population over 18 in each province obtained as mentioned in the "Table 1". It is worth mentioning that there are different figures about Afghanistan's population and population rates which are all based on approximate estimation, not the general population census that is common in almost all countries.

\section{The sample size estimation}

The sample size in this survey was considered 1,500 respondents which after car eful calculation of the population considering each province, the final figure was increased up to 1,540 . To have an accurate size in each sample size, some changes were applied on some provinces. Including provinces whose sample size were less than 50 people, to make it admissible, the number increased to 50 . Also to simplify calculations and divisions of the urban and rural populations and gender groups (male and female), the sample size in some provinces became the multiple of 10 (Table 2).

Table 2: The preliminary and the final sample size

\begin{tabular}{|c|c|c|c|}
\hline No & Province & The preliminary sample size & The final sample size \\
\hline 1 & Badakhshan & 83 & 80 \\
\hline 2 & Badghis & 44 & 50 \\
\hline 3 & Balkh & 113 & 110 \\
\hline 4 & Bamyan & 38 & 50 \\
\hline 5 & Ghazni & 104 & 100 \\
\hline 6 & Ghor & 61 & 60 \\
\hline 7 & Helmand & 74 & 70 \\
\hline 8 & Herat & 157 & 160 \\
\hline 9 & Jawzjan & 48 & 400 \\
\hline 10 & Kabul & 398 & 100 \\
\hline 11 & Kandahar & 98 & 80 \\
\hline 12 & Kunduz & 83 & 130 \\
\hline 13 & Nangarhar & 130 & 50 \\
\hline 14 & Paktia & 46 & 50 \\
\hline 15 & Zabul & 24 & 1,540 \\
\hline & Total & 1,500 & 500 \\
\hline
\end{tabular}

Since in this survey the variable of being urban or rur al is very important, we have tried the sample size of the urban and rural populations to be proportional with regard to the provinces covered by the survey. "Table 3 " shows the sample size of 
urban and rural populations in 15 provinces. The figures in this table are based on the estimated statistics provided by the Central Statistics Organization'.

According to the Central Statistics Organization, urban population in some of the provinces covered by this study was less than 10 percent. After an accurate calculation to obtain the ratio of urban and rural population of the samples, the sample size for urban population in some provinces was found to be less than 10 people. So in order to reach an acceptable figure, we have raised it to 10. As it is shown in the "Table 3", this change was applied on the sample size of the provinces of Badakhshan, Badghis, Ghor, Bamyan, Jawzjan, Helmand, Ghazni, Paktia and Zabul.

Table 3: The final sample size categorized by urban and rural

\begin{tabular}{|c|c|c|c|}
\hline No & Province & The rural sample size & The urban sample size \\
\hline 1 & Badakhshan & 70 & 10 \\
\hline 2 & Badghis & 40 & 10 \\
\hline 3 & Balkh & 70 & 40 \\
\hline 4 & Bamyan & 40 & 10 \\
\hline 5 & Ghazni & 90 & 10 \\
\hline 6 & Ghor & 50 & 10 \\
\hline 7 & Helmand & 60 & 10 \\
\hline 8 & Herat & 110 & 50 \\
\hline 9 & Jawzjan & 40 & 10 \\
\hline 10 & Kabul & 60 & 340 \\
\hline 11 & Kandahar & 65 & 35 \\
\hline 12 & Kunduz & 60 & 20 \\
\hline 13 & Nangarhar & 110 & 20 \\
\hline 14 & Paktia & 40 & 10 \\
\hline 15 & Zabul & 40 & 10 \\
\hline & Total & 945 & 595 \\
\hline
\end{tabular}

\section{Questionnaire design}

The first step to prepare the draft questionnaire of the peace talks was to study various researches, books and articles on the subject of peace and peace talks. In the second step, the research team hosted a roundtable to investigate the different aspects of the issues of war and peace in Afghanistan. The participants of this 
meeting which was held at the institute's office were military and security experts, university professors, researchers and civil society activists. The mentioned steps helped to draft questionnaire for the survey. Therefore, it could be said that it is a researchers made questionnaire. In the next step, the dr aft was available to the other researchers of the institution and all the questions were reviewed and discussed in details by the group.

Then the draft was given to a number of professors of private universities in Kabul and also Mr. Sadeghi (a researcher and professor at the Tehran University) for more consideration and eventually applied their reviews and opinions about some of the questions. After all these steps, more changes were brought into the questionnaire including addition, omission and modification in some of the questions.

Next, to assess the content validity of the questionnaire, it was pilot tested with 30 residents of Kabul from different walks of life. After the pilot-test, changes were applied to a number of sentences structure (in terms of expression, the number of answers options, words replacements, etc.). Also some of the questions were excluded. Finally, the questionnaire was tested again with 10 residents of Kabul that resulted in slight changes to the questionnaire.

The questionnaire of this survey was finalized after differ ent stages of review and primary and secondary tests. The final questionnaire is available in the annex. After discussing it with the project consultant Dr. Sadeghi (professor at the Tehran University), the questionnaire was translated into Pashto. It was sent to the provinces in the two versions, Pashto and Dari, for the fieldwork.

\section{The interviewer's team and fieldwork}

The fieldwork of this survey was carried out by 30 field interviewers. Most of them were trained directly by the research team of the institute in its office in Kabul. So, there was a certainty about their ability and discretion to do the survey. About the other interviewers who cannot make their presence in trainings in Kabul were guided through telephone and Skype conversations. In these tutorial sessions, all the questions of the questionnaire were read one by one and every ambiguity had been cleared by the institute researchers. In addition, to make sure of their thorough understanding of the work and not to leave any question for them, it was asked from the interviewers themselves to be the first one answering the questionnaire. So, a lot of questions and ambiguities of the field interviewers were identified and eventually was answered by the research team.

\section{Process monitoring and quality control of the data collection stages}

1) The team of field interviewer's selection: Afghan Institute for Strategic Studies has done many surveys during the past two years. Amongst, it managed to 
accomplish four important studies. The successful researches ar e following:

8. Corruption mapping in Afghanistan

9. Trends in Radicalization Across Unregistered Madrassas in Afghanistan

10. Social Media and Articulation of Radical Narratives in Afghanistan

11. Trends of Radicalization among the Ranks of the Afghan National Police

The institute's team of field interviewers for this survey has been selected among the most experienced people who have worked with the institute in the previous surveys. The education level of the interviewer's team starts from the Associated Degree to Master Degree. In order to improve the quality of the data collected by this survey, the field researchers were selected from the local people of provinces cover ed by this study.

2) How to fill the questionnaire?: Although the selected interviewers to do the survey were selected among the best ones according to the evaluation rates of the institute's interviewers, but they also received necessary training about how to implement the survey in the provinces and about how to fill each item in questionnaire, in person, by phone or Skype.

3) During the survey interviews, a number of supervisors were assigned to help the interviewers and monitor the accuracy of the survey implementation. In addition, all interviewers were obliged to provide detailed weekly report of their work to the field coor dinators by the end of the week. 
Study findings and results

\section{Demographic characteristics of respondents}

\section{Gender}

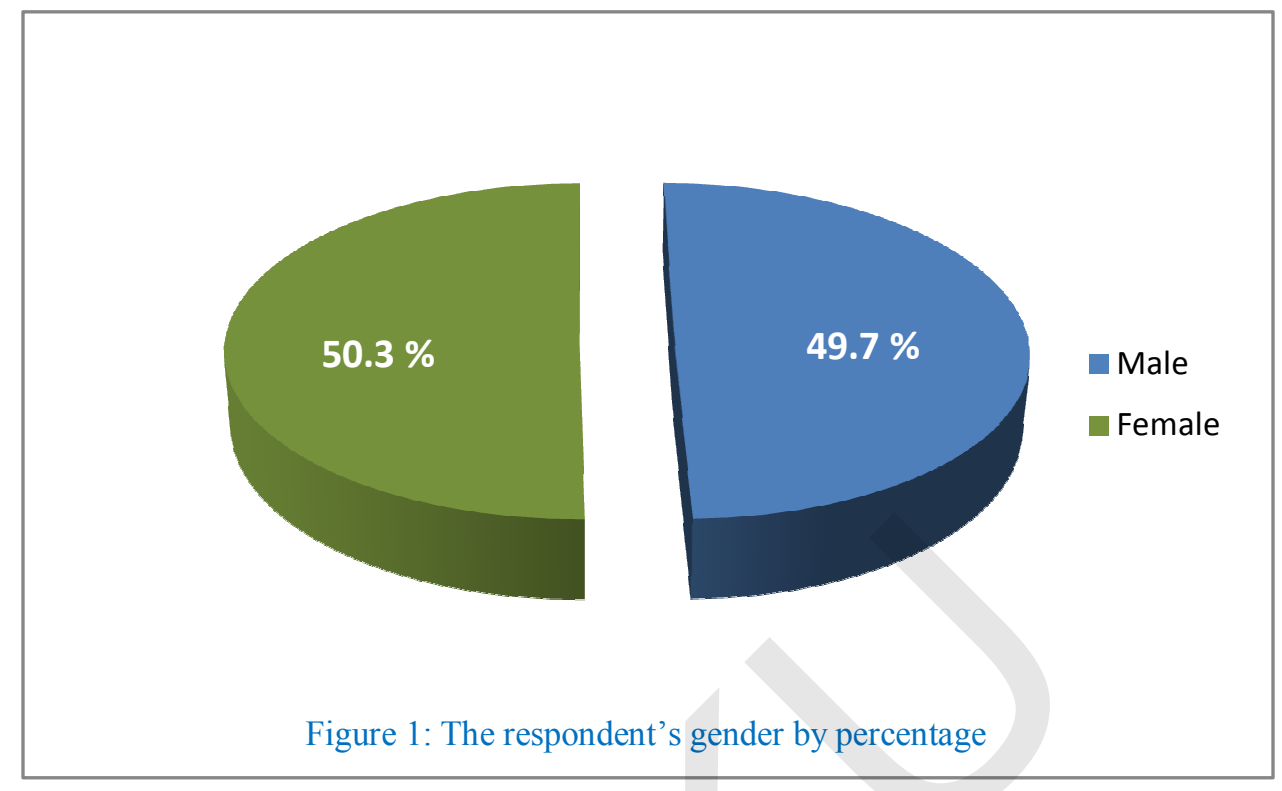

Figure 1 shows the gender of respondents in this survey. From the whole 1,540 people which were cover ed by this survey in the 15 provinces, $50.3 \%$ are female and $49.7 \%$ are male. The sample size of women and men were near to each otheralmost equal.

\section{Age groups}

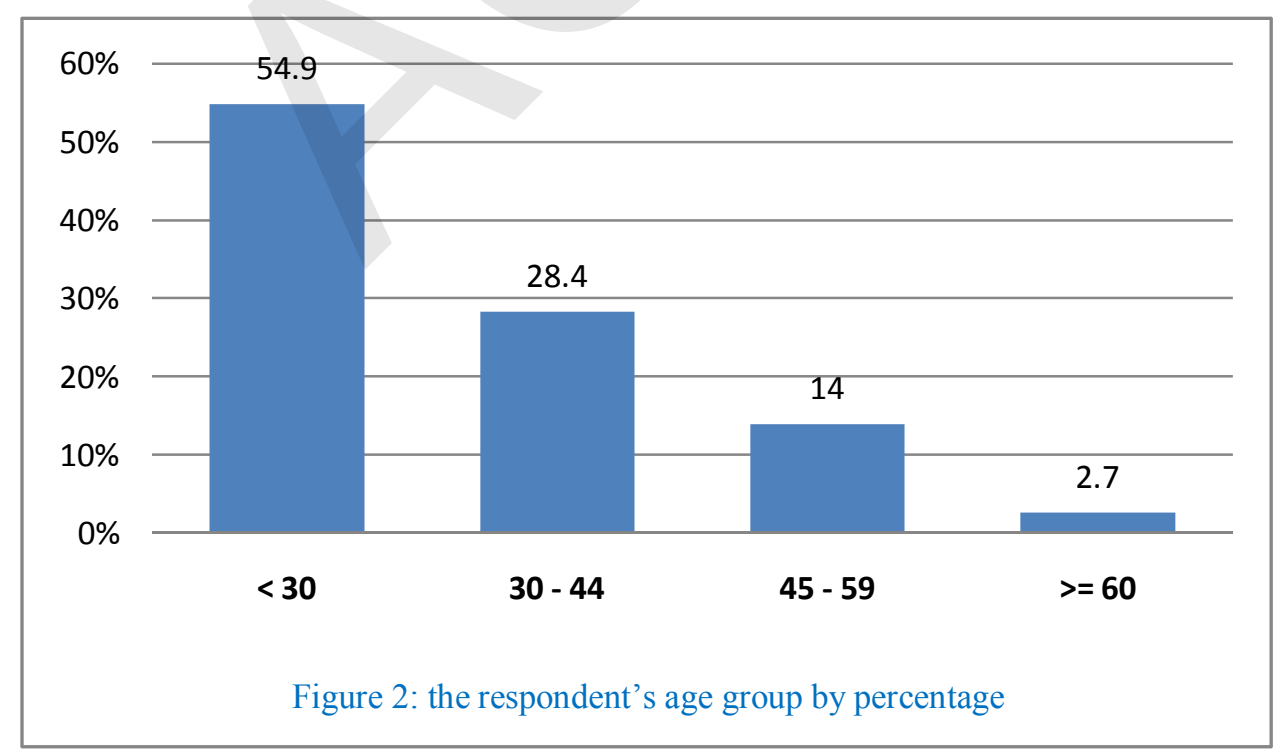

Figure 2 shows the age groups of respondents. People under the 30 years of age are the largest group of the respondents $(54.9 \%)$ which is followed by people aged 30 to $44(28.4 \%)$. People aged 45 to 59 constitute the third largest group of the respondents (14\%). 


\section{Education}

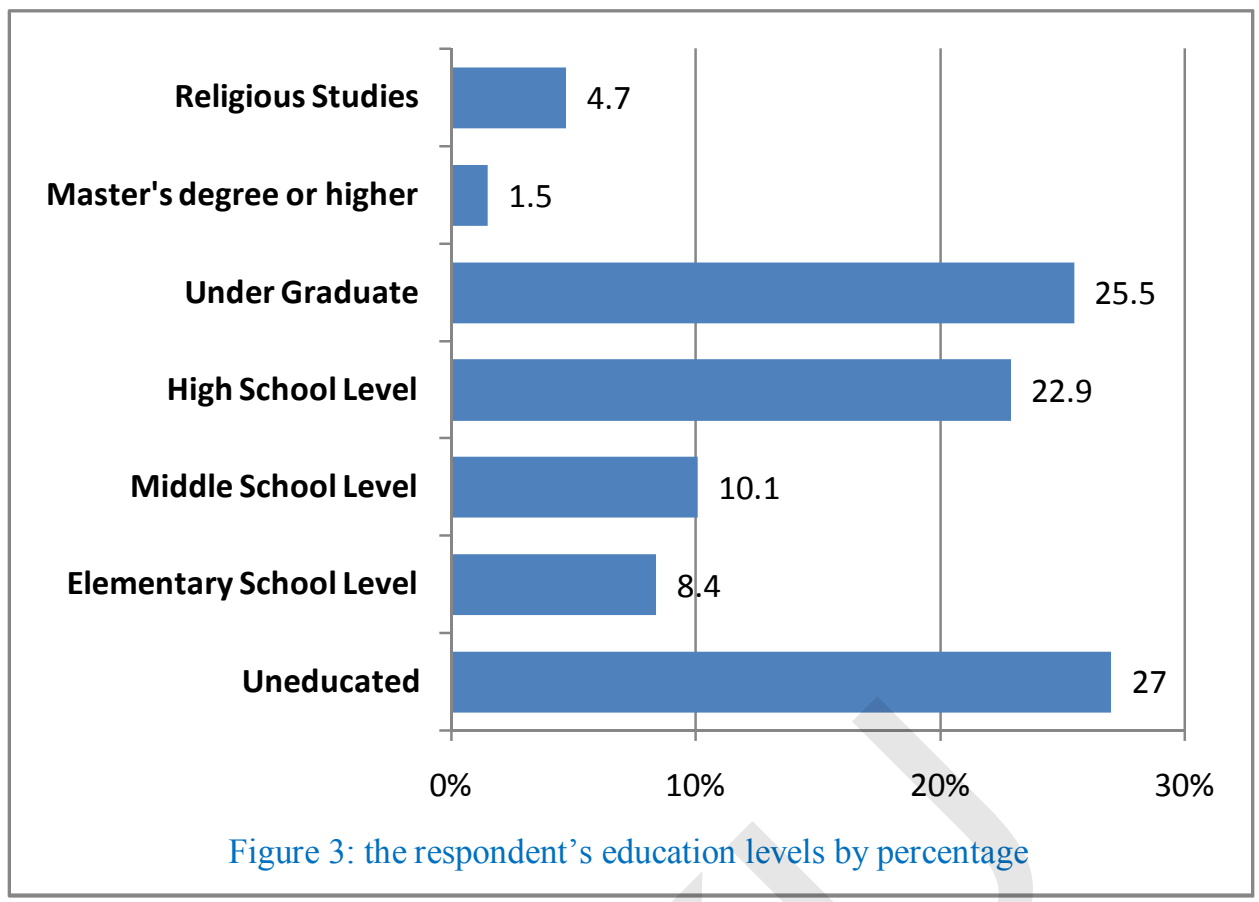

Figure 3 represents the respondents' levels of education. The majority of the surveyed groups are "uneducated or little educated" $(27 \%)$ which is followed by "students, associated degrees, and bachelors" (25\%) and "high school diplomas" (23\%). Religious educated respondents (4.7\%) and master and above it (1.5) were the least figures.

\section{Place of living}

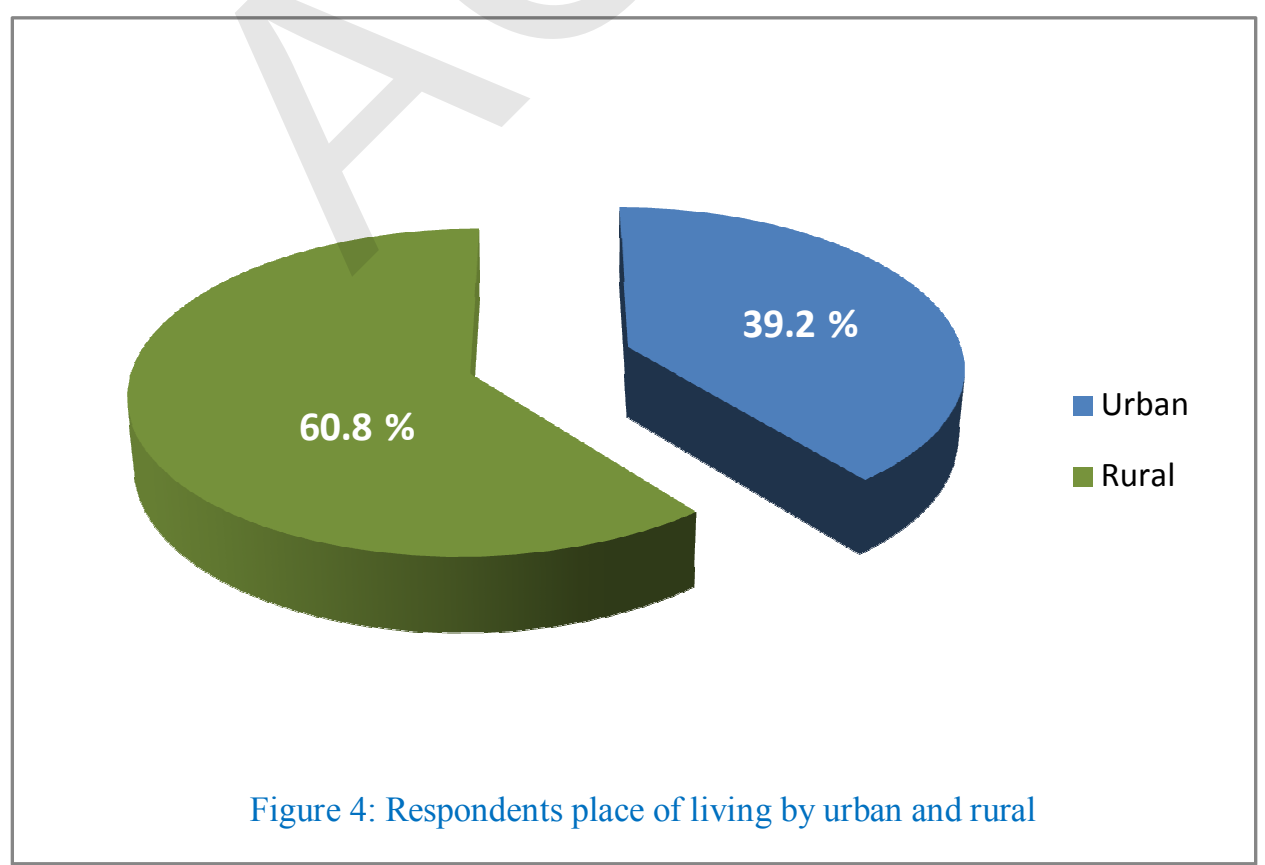

Figure 4 shows the respondents place of living by separation of rural and urban ar eas. $60.8 \%$ of the poll respondents are rural, and $39.3 \%$ are urban. 


\section{Marital Status}

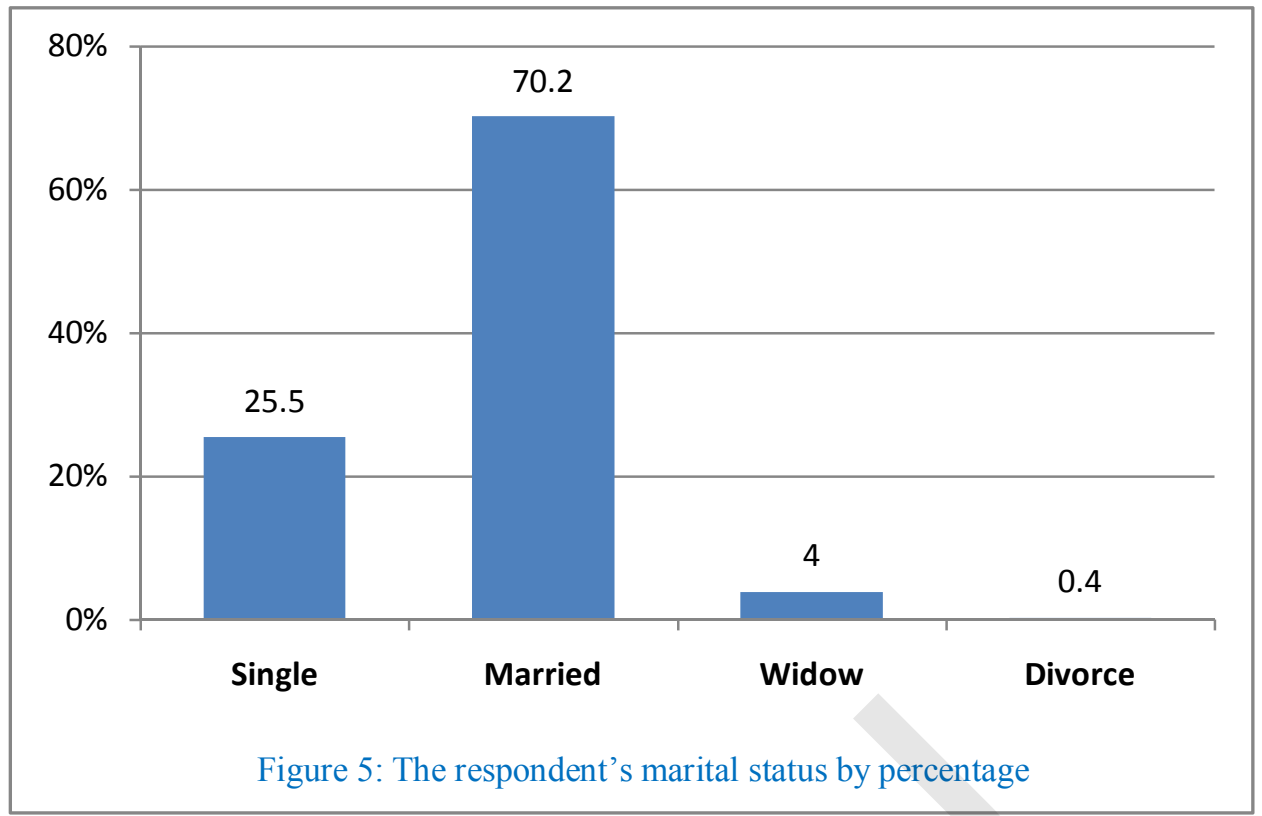

Figure 5 shows the marital status of the respondents. Almost $70 \%$ of the respondents are married; $25 \%$ are single; widows by $4 \%$ and divorced by $0.4 \%$ are next.

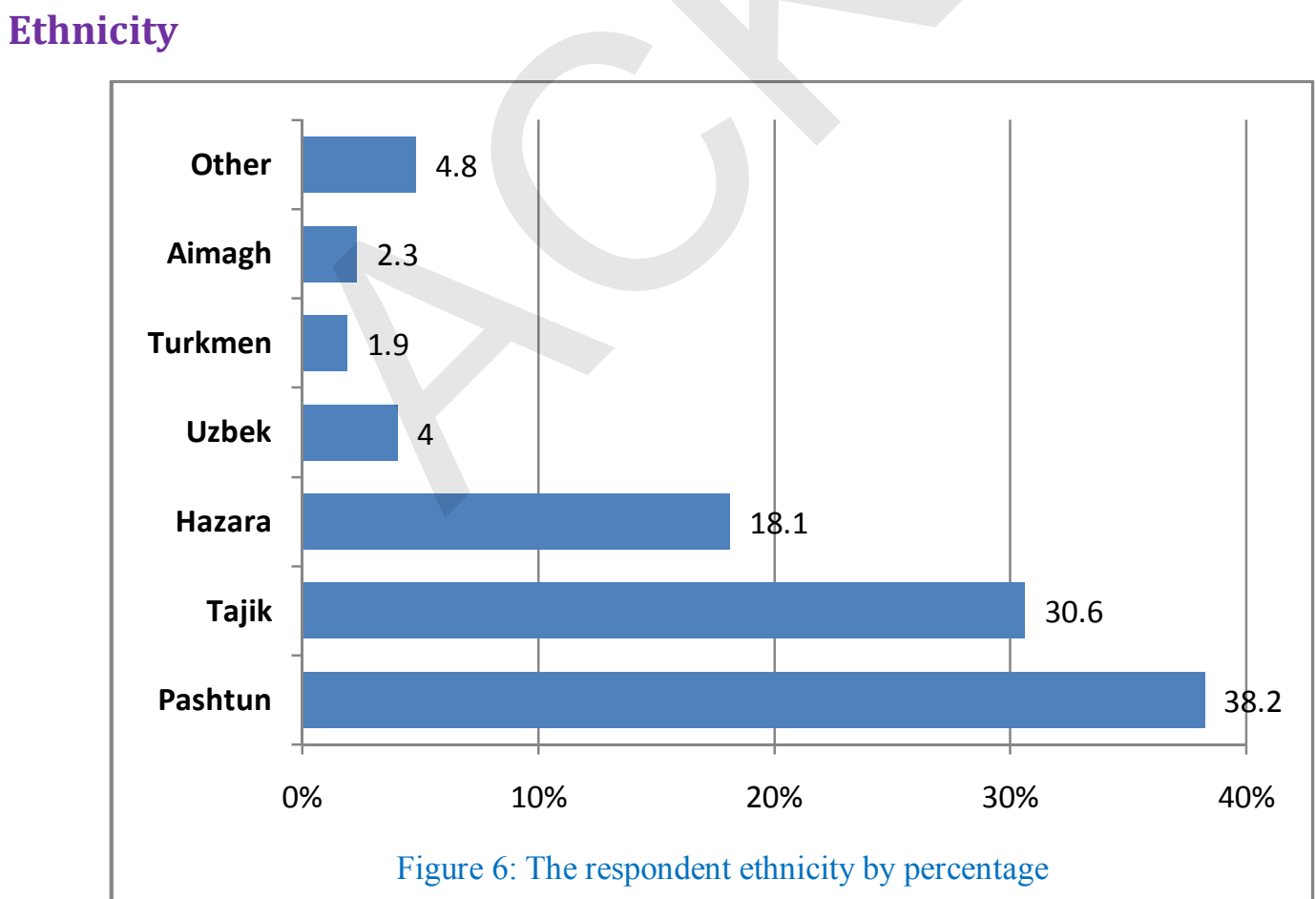

Figure 6 shows the respondents' ethnicity. Pashtuns are the largest ethnic group of the survey respondents with $38 \%$, Tajiks are the second largest with $30.6 \%$, and Hazar as with almost $18 \%$ are the third. The other ethnicities which are included in this survey are Uzbeks with 4\%, "Aimaghs" with $2.3 \%$, and "Turkmen" with about $2 \%$. 


\section{Survey territory}

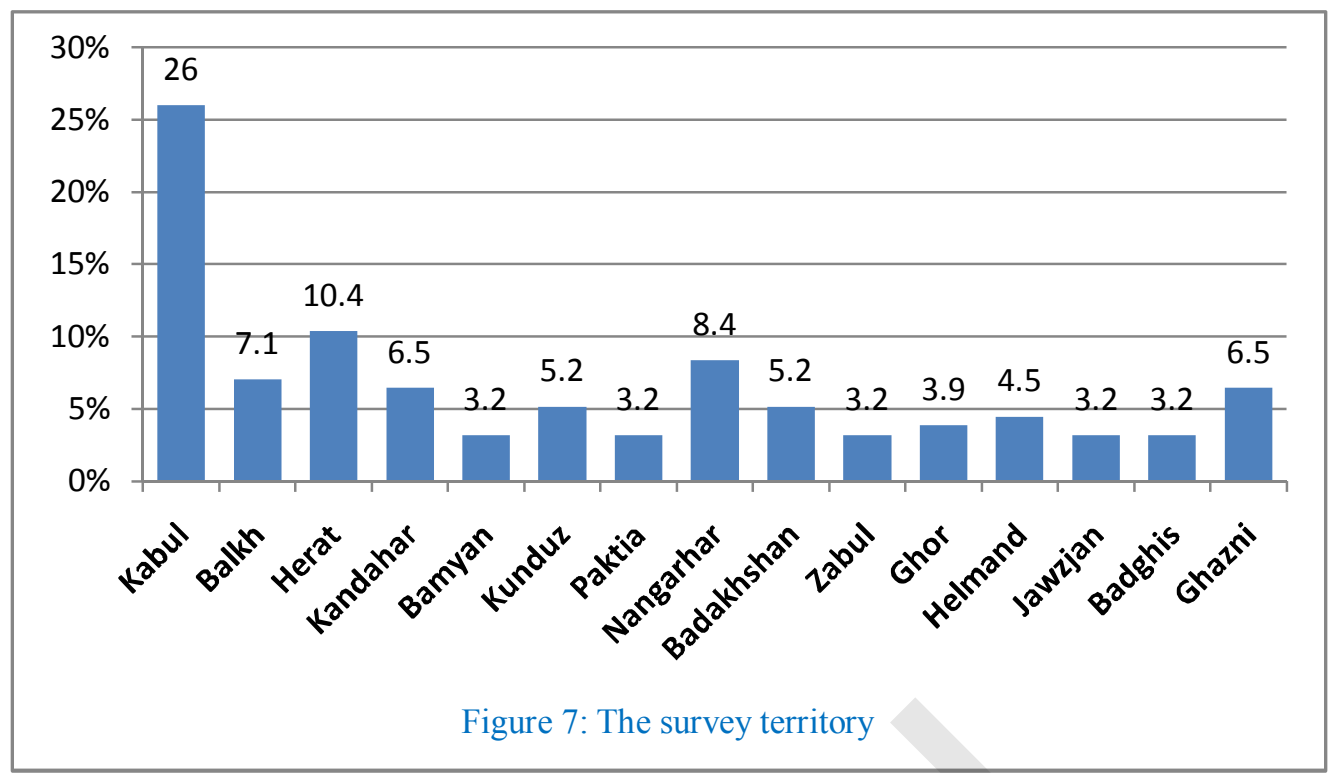

Figure 7 shows the percentage of the respondents in each province from the whole sample size. The sample size in this survey was 1,540 people. The percentage of the respondents in each province was calculated in accordance with its population ratio to Afghanistan's total population. More details about it can be found in the methodology chapter.

\section{Detailed survey results}

Feeling of safety in the place of living (town or village)

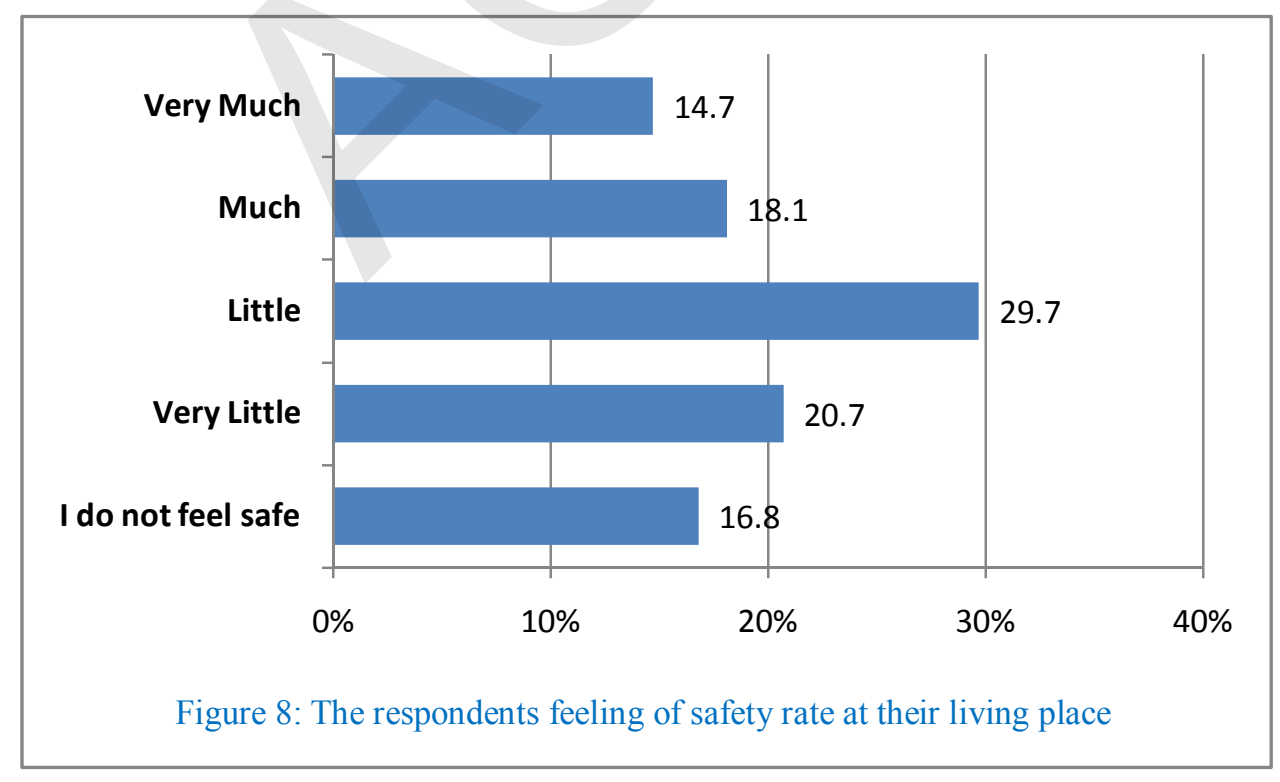

Figure 8 shows how much the respondents feel safe in their place of living. Most of the respondents have "little" (29.7\%) or "very little" (20.7\%) sense of safety. $16.8 \%$ of the respondents "don't feel safe" in their place of living. About $18 \%$ feel "high" safe and $14.7 \%$ feel safe at a "very high" level. 


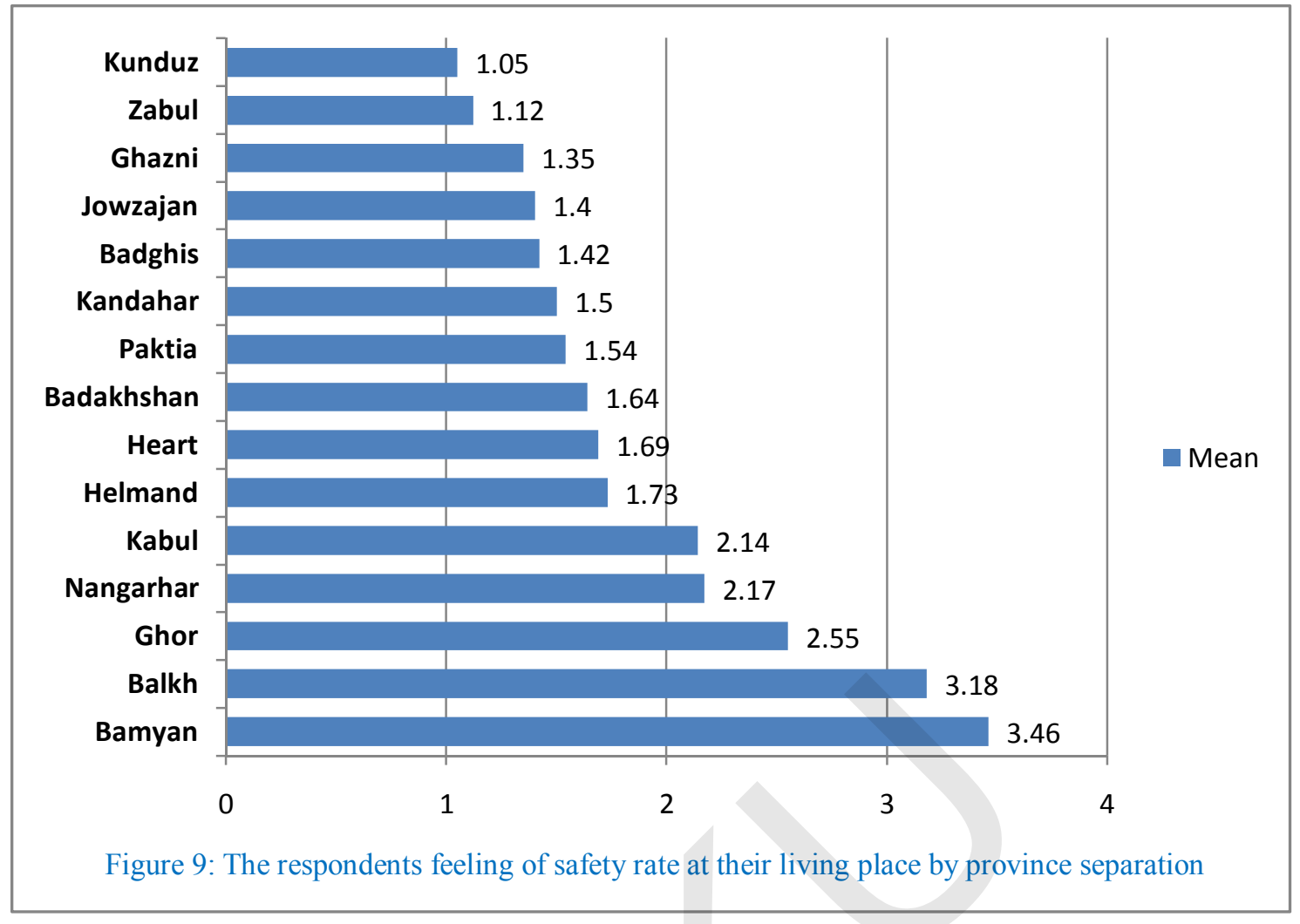

Figure 9 shows the respondents' mean sense of safety by each province. The mean calculated from the change of response codes: I do not feel safe: 0 , very little: 1 , little: 2, high: 3 , very high: 4 . The highest sense of safety at the place of living were in the provinces of Bamyan (3.46), Balkh (3.18) and Ghor (2.55). While the lowest mean is given to the provinces of Ghazni (1.35), Zabul (1.12), and Kunduz (1.05).

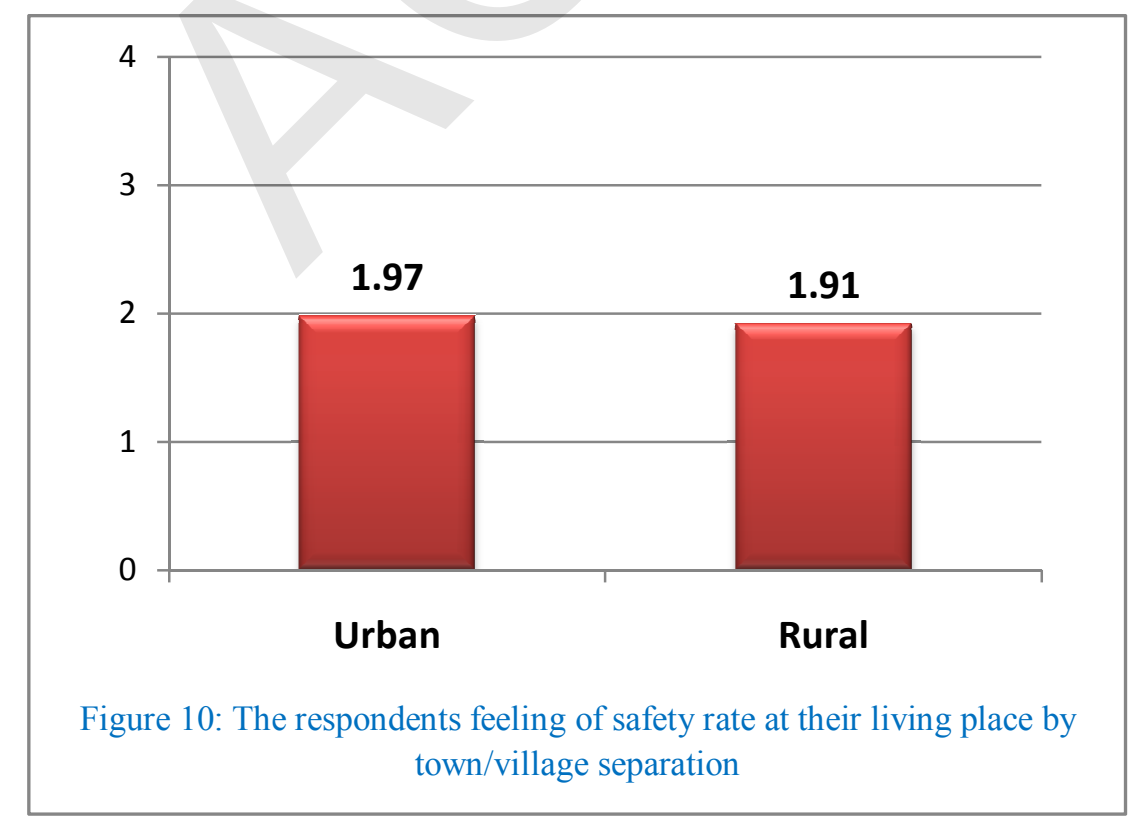

Figure 10 shows the rate for the sense of safety meaning by the urban and rural categories. According to the figure, there is not much difference in sense of safety between the urban and rural population. 


\section{Peace talks news follow up}

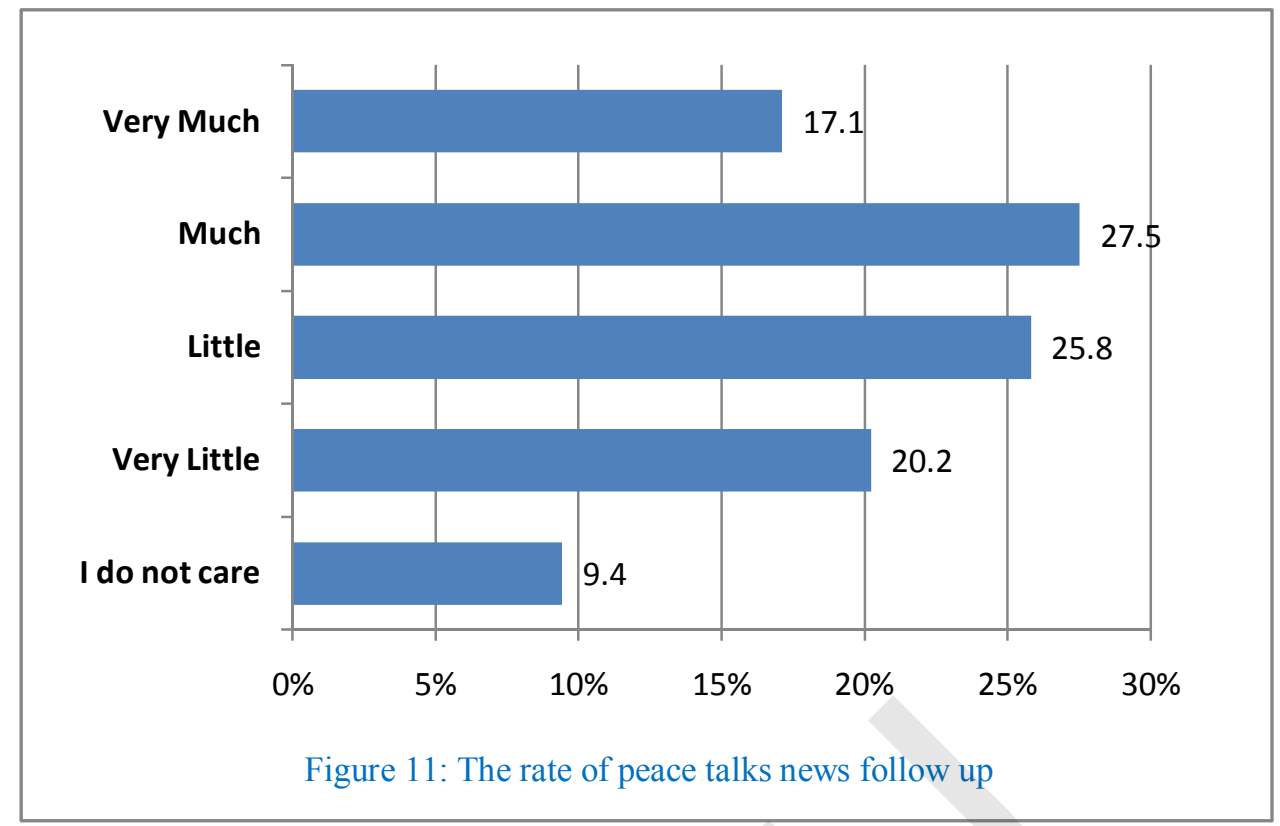

Figure 11 indicates how much the respondents follow the news about the peace talks between the government and the Taliban. $44.6 \%$ of the respondents were following this issue to an extent of "High" (27.5\%) and "very high" (17.1\%). For 46\% of the respondents described the level of follow up about the issue as "little" $(25.8 \%)$ and "very little" (20.2\%). And $9.4 \%$ of the respondents were not following news of the peace talks at all.

\section{People's views toward the Taliban}

In this chapter, general views of people toward the Taliban have been analyzed by using some of questions in the questionnaire.

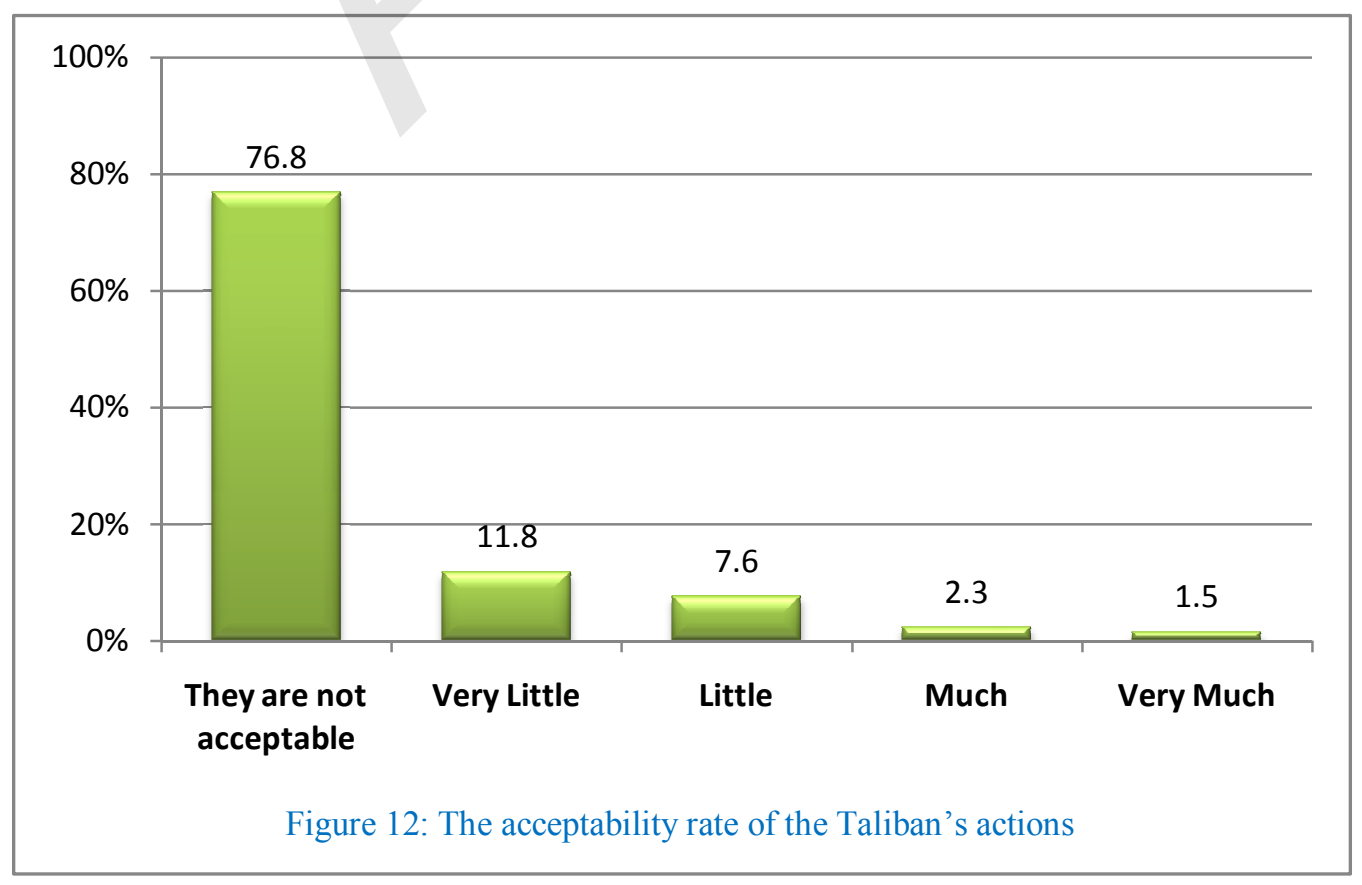


Figure 12 (previous page) indicates the acceptability rate of the Taliban's actions in people's views. $76.8 \%$ of the respondents believe that the Taliban's behaviors "are not acceptable". $11.8 \%$ of the respondents selected option "very little" and $7.6 \%$ selected option "little". (Followed by 1.5\% "very high" and 2.3\% "high")

Figure 13 shows a range of the reasons for the Taliban to fight with the Afghan government. The relative majority of the respondents (28.4\%) believe that the main reason Taliban are fighting with the government is "to assure the interests of Pakistan". $25.9 \%$ thinks they are fighting for "the power". Almost $13 \%$ believe they are fighting for "for eign countries interests". In the views of $12.5 \%$, the main reason is "foreign troops' presence". Interestingly, only $4.3 \%$ actually believe they are fighting "to defend Islam".

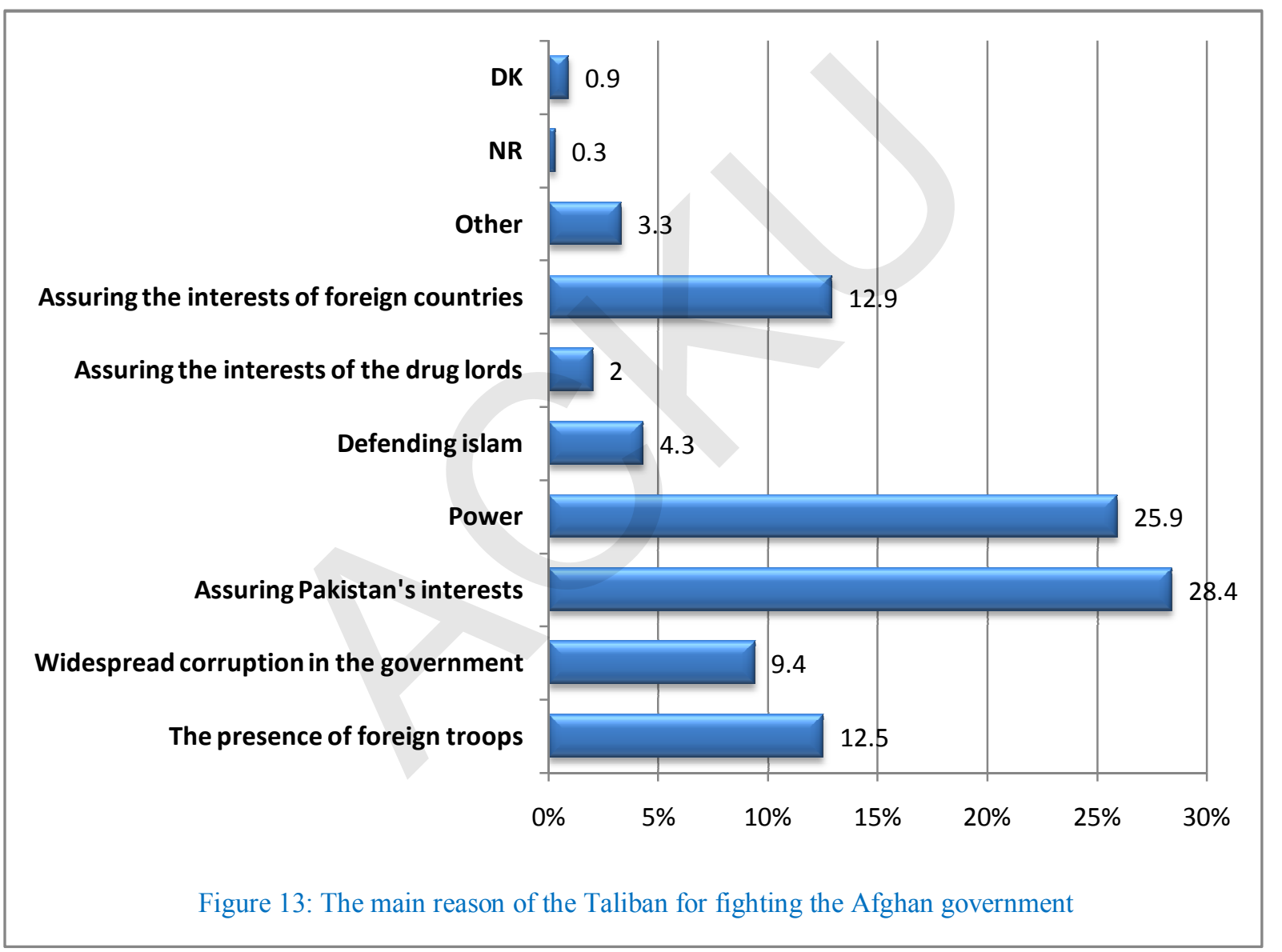

Figure 14 (next page) indicates the interviewees' responses to the question "what is the appropriate title for naming the Taliban?'

$63.3 \%$ of the respondents selected the titles "enemy" (24.4\%), "ter rorist" $(19.9 \%)$, and "mercenaries" $(19 \%)$. Only $1.8 \%$ of the respondents agreed on the title "Mujahidin" for the Taliban. Almost 33\% believed the titles "political opponent" (13\%), "dissatisfied brothers" (10.1\%), and "insurgents" (9.8\%) are appropriate for Taliban. $1.2 \%$ of the respondent did not answer this question and $0.8 \%$ selected the option "I don't know". 


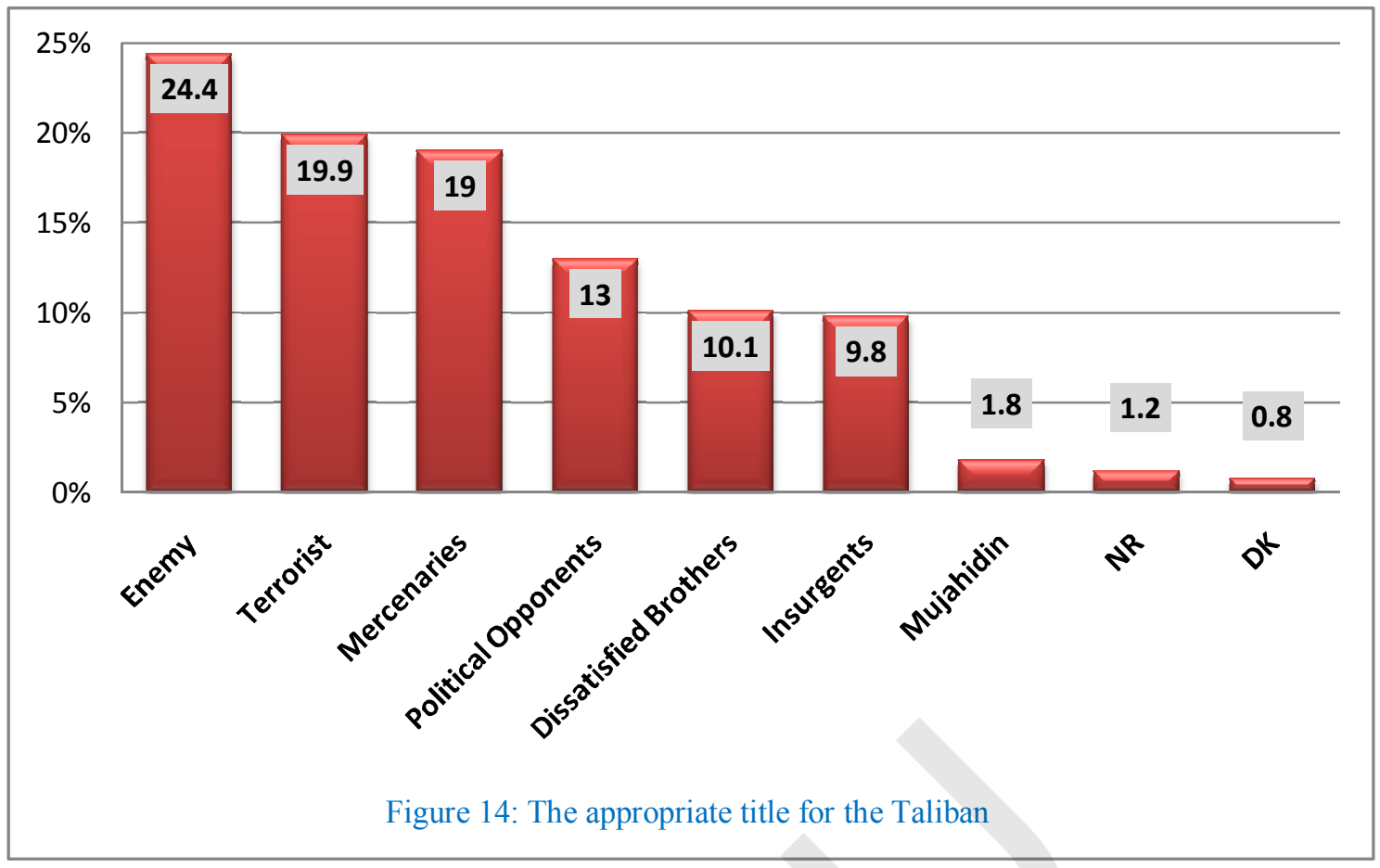

Figure 15 shows the ratio of the answer to the question of "Taliban title" separated by the respondents' place of living (urban/rural). 72.5\% of urban respondents believed the titles "terrorist" (26.2\%), "enemy" (24.8\%) and "mercenaries" (24.5\%) are appropriate. 54.7\% of rural respondents selected the titles "enemy" (24\%), "mercenaries" (17.3\%), and "terrorists" (15.9\%) for the Taliban. A higher percentage of the rural respondents (2.6\%) consider ed "Mujahidin" as an appropriate title, than the urban respondents $(0.7 \%)$.

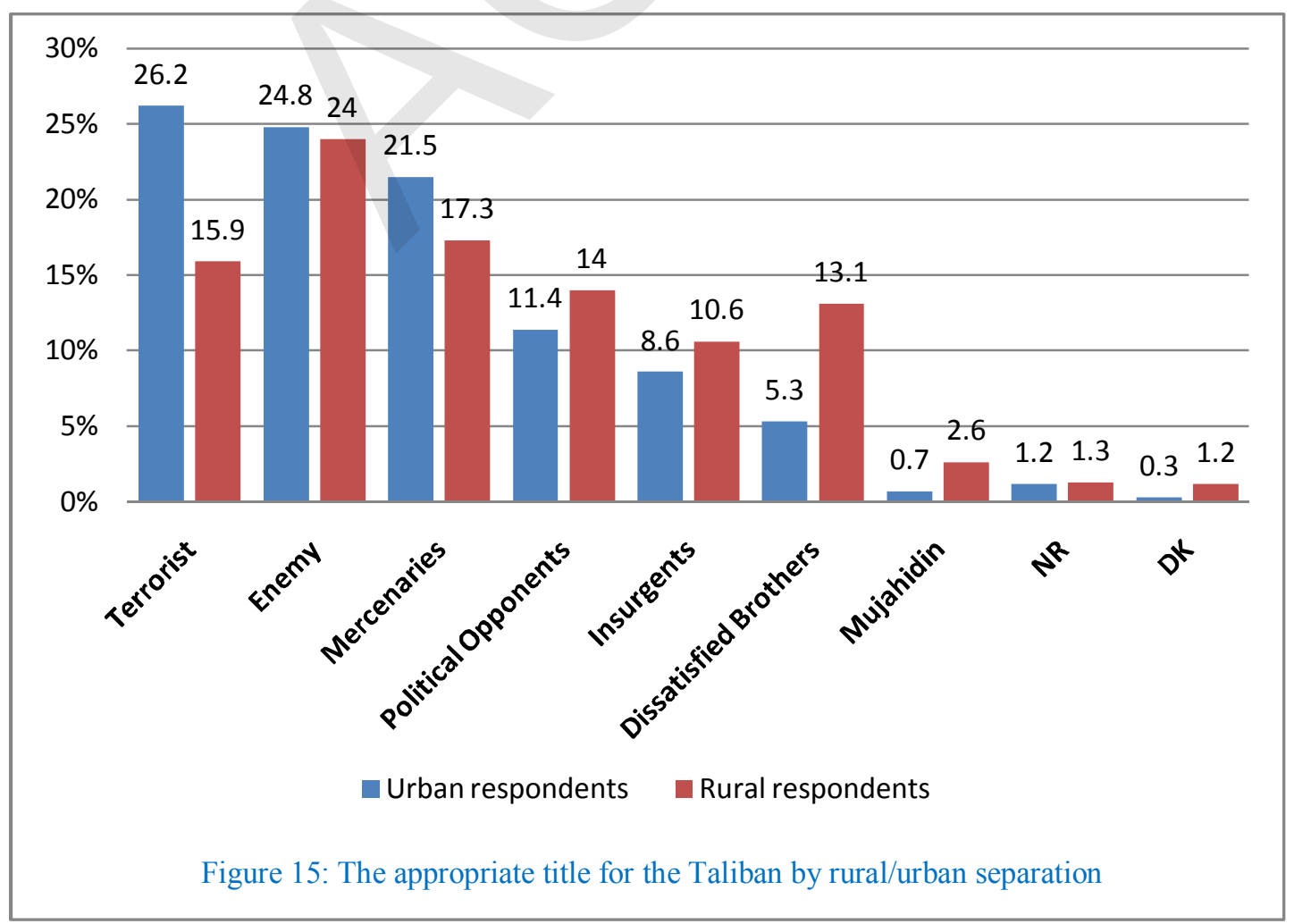




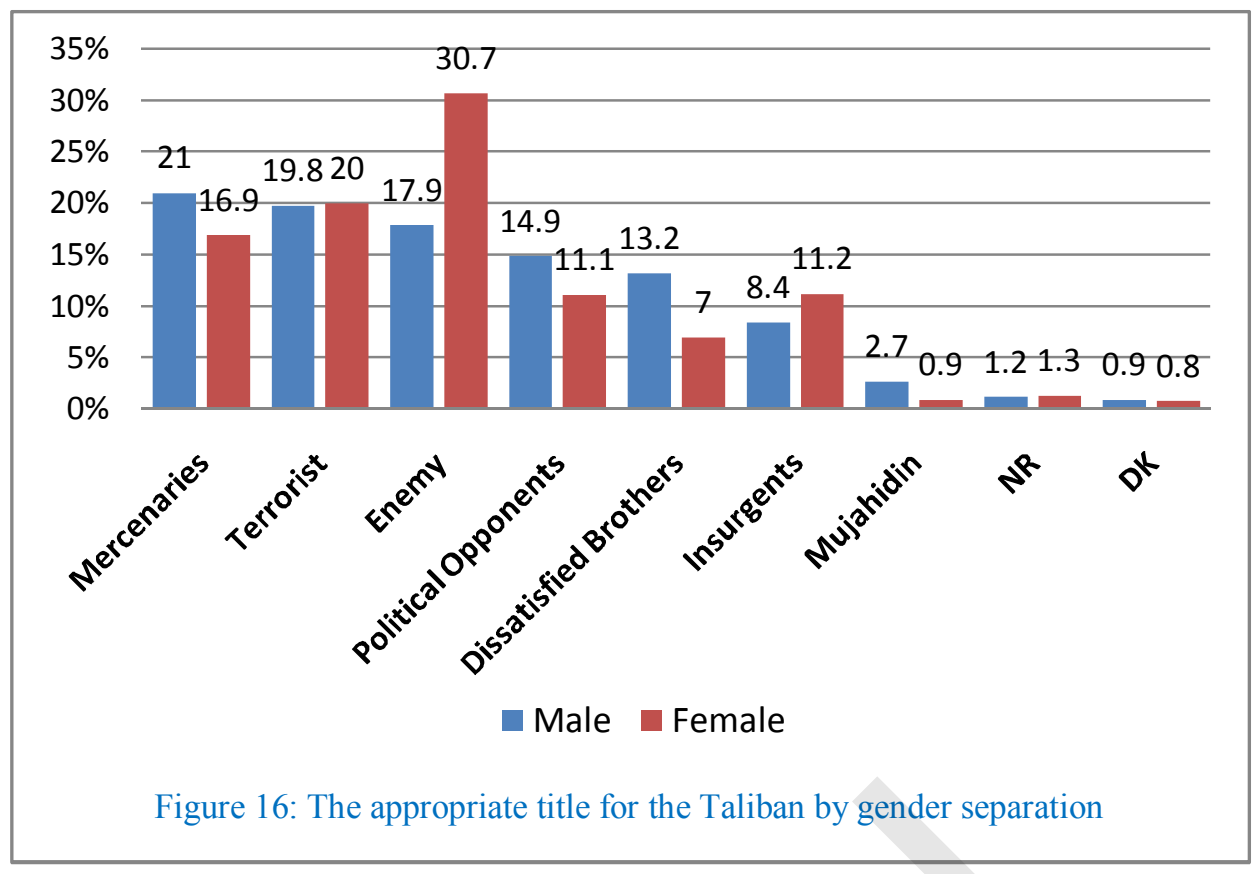

Figure 16 shows the selected titles for the Taliban, grouped by the gender of the respondents. $67.6 \%$ of the female respondents believed the titles "enemy" $(30.7 \%)$, "terrorists" $(20 \%)$ and "mercenaries" $(16.9 \%)$ are appropriate for the Taliban. Accordingly, $58.7 \%$ of male respondents selected the tittles "mercenaries" $(21 \%)$, "terrorists" (19.8\%), and "enemy" (17.9\%). Also the higher percentage of male respondents $(2.7 \%)$ believed "mujahidin" is appropriate title to be used for the Taliban as compared to female respondents $(0.9 \%)$.

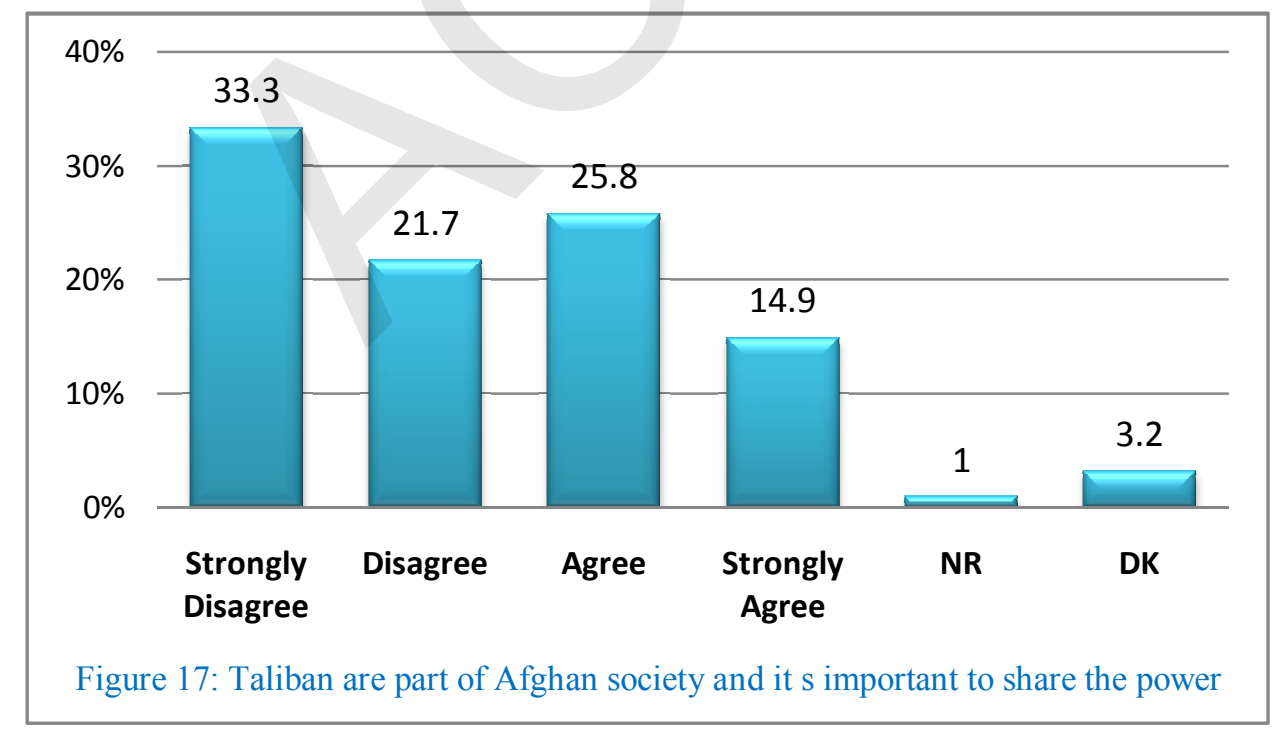

Figure 17 indicates how much the respondents agree or disagree with the statement "the Taliban are part of Afghan society and it is important to share power". Totally, $55 \%$ of the respondents "disagree" by the statement $(33.3 \%$ strongly disagree, $21.7 \%$ disagree). $40.7 \%$ of the respondents "agree" with the statement (25.8\% agree, almost $15 \%$ strongly agr ee). 


\section{Women and peace talks}

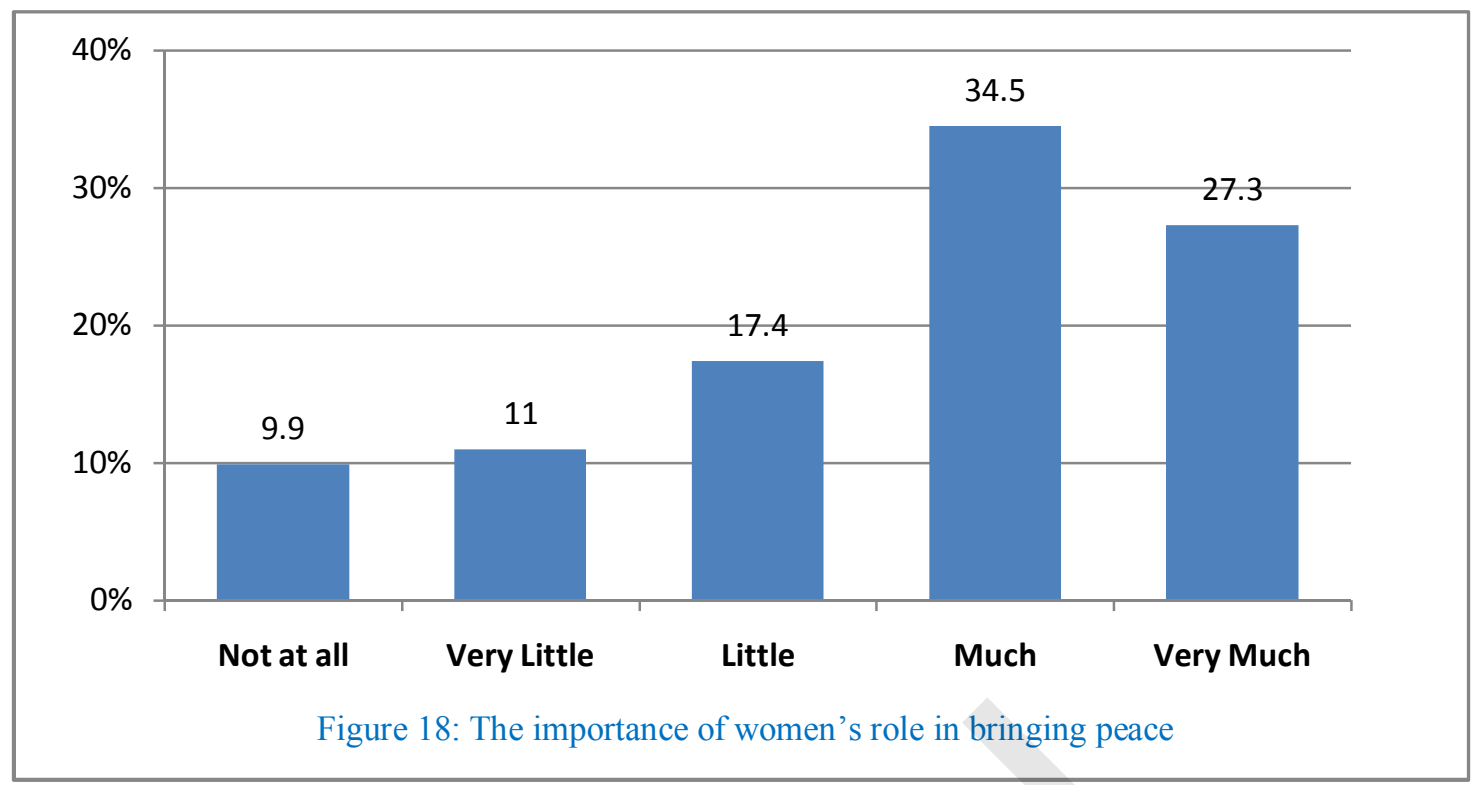

Figure 18 shows the importance of women's role in peace process. Almost $62 \%$ of the respondents described it as an important which amongst, 34.5\% believed it has "high" importance and 27.3 thought it has "very high" importance. About $28 \%$ of the respondents described its importance level as "little" (17.4) and "very little" (11\%). And nearly $10 \%$ thinks women's role in peace process "is not important".

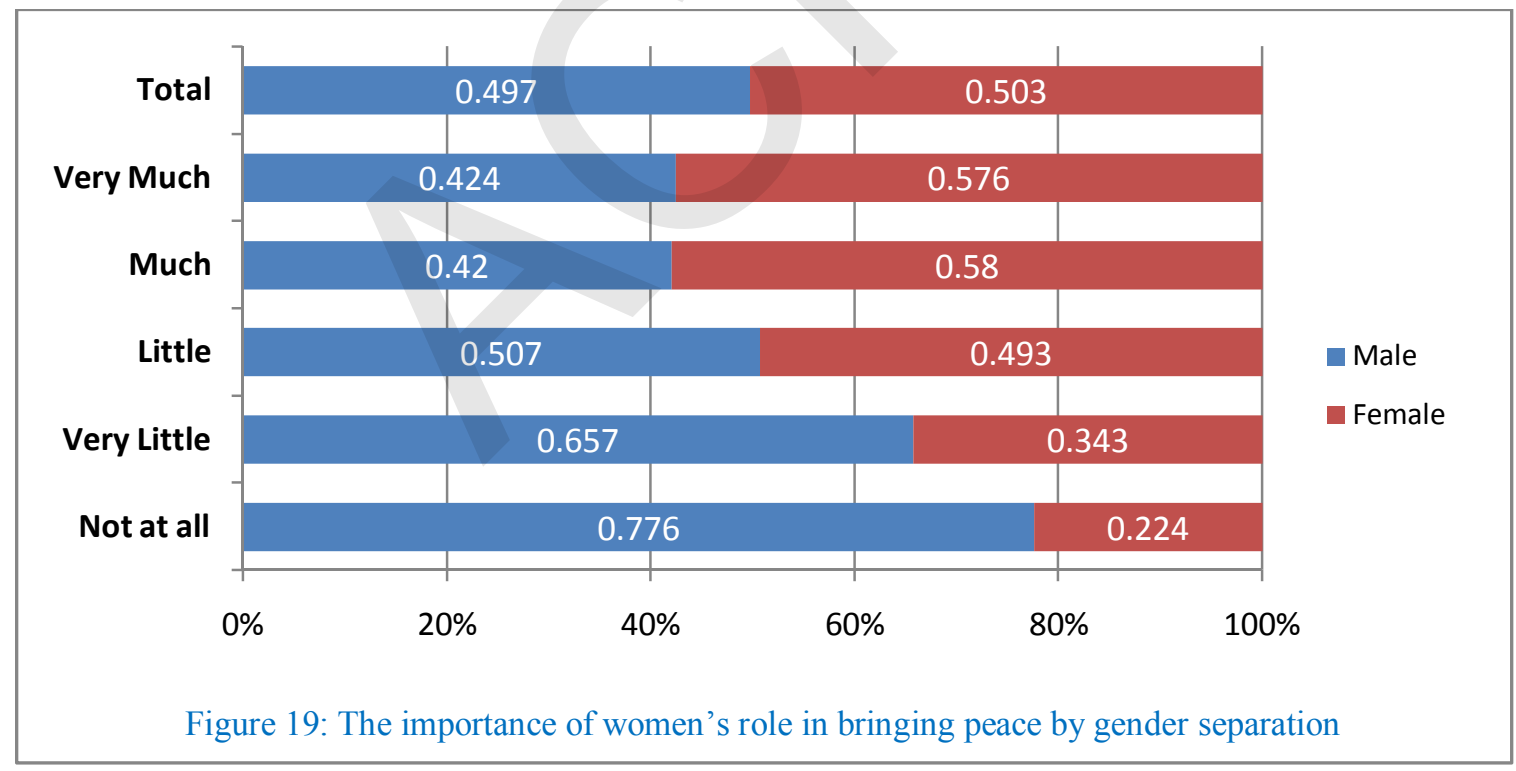

Figure 19 indicates the opinions about the importance of women's role in peace making by the gender groups. $77.6 \%$ of the respondents whose answers was "not important" were men, and the $22.4 \%$ were women. $65.7 \%$ of the ones who selected "very little" were men and $34.3 \%$ were woman. Amongst interview ees who selected the option "very high", 42.4\% were men and $57.6 \%$ were women. Female respondents believe in the importance of women's role in bringing peace than male respondents. 
Figure 20 shows the effects of peace with the Taliban on the status of women. $60.2 \%$ of the respondents believed that "the status of women gets worse", $10.8 \%$ thought "the status of women gets better", and $18.7 \%$ believed that "the status of women will not change".

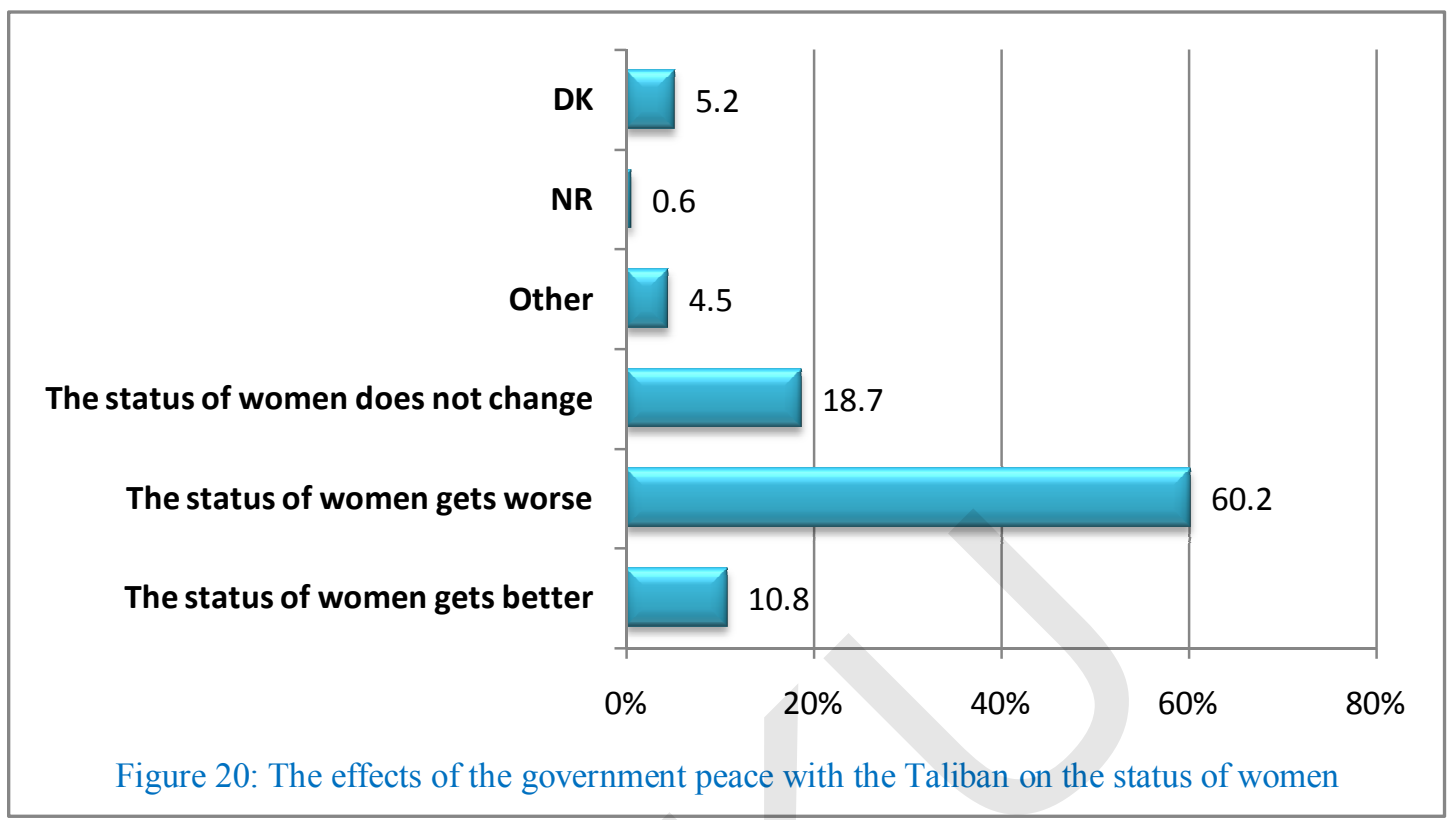

Figure 21 shows the opinions on the effects of government peace with the Taliban on the status of women, by gender groups. Almost $67 \%$ of female and almost $53 \%$ of male respondents believed that "the status of women gets worse". $8.8 \%$ of female and $12.8 \%$ male respondents thought "the status of women gets better".

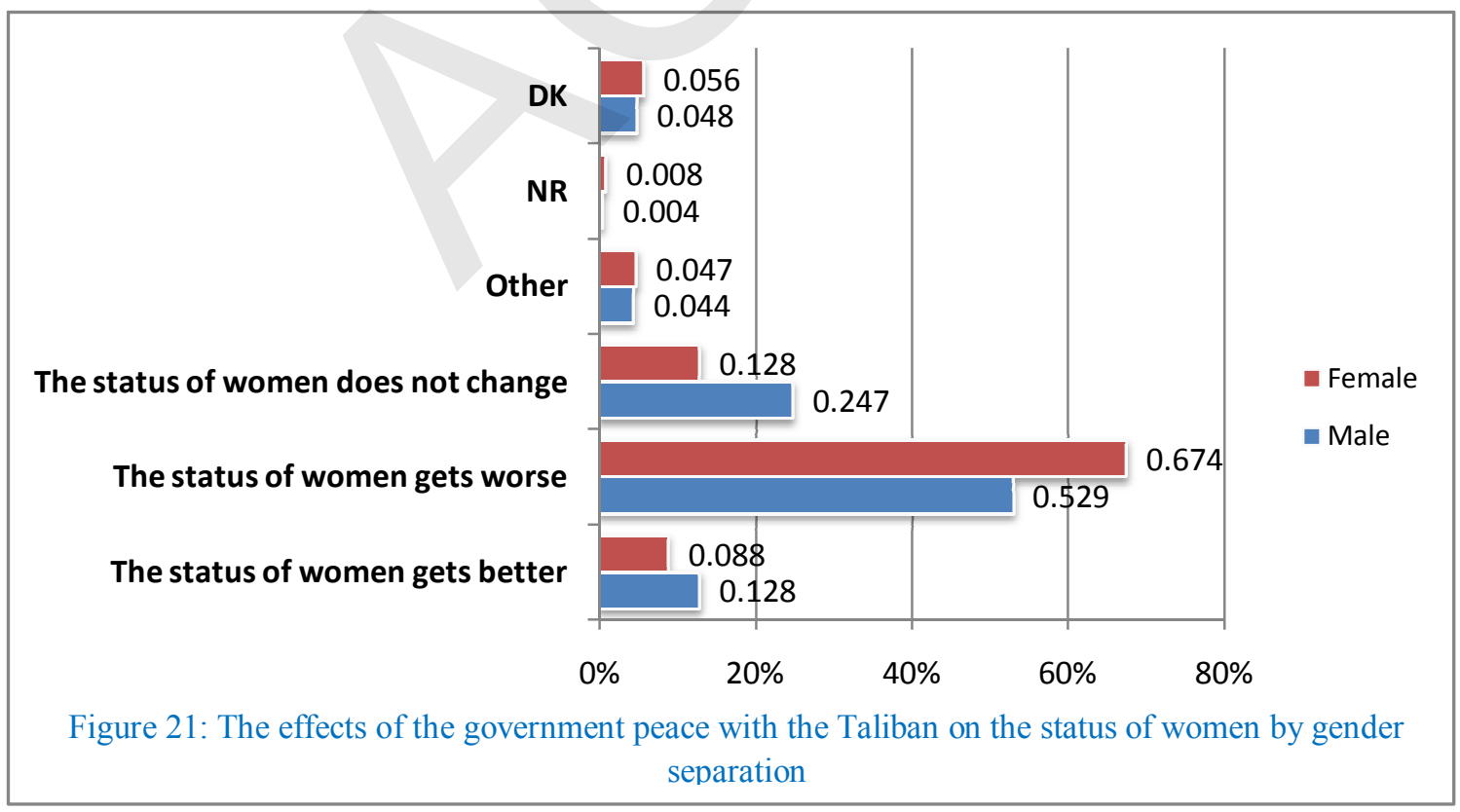

Figure 22 shows the impact of peace with the Taliban on the status of women, by the respondents' place of living (urban and rural). $67.1 \%$ of the urban respondents and $55.8 \%$ of rural respondents believed that "the status of women gets worse". 
$11.4 \%$ of the rural respondents and nearly $10 \%$ of the urban respondents believed "the status of women gets better".

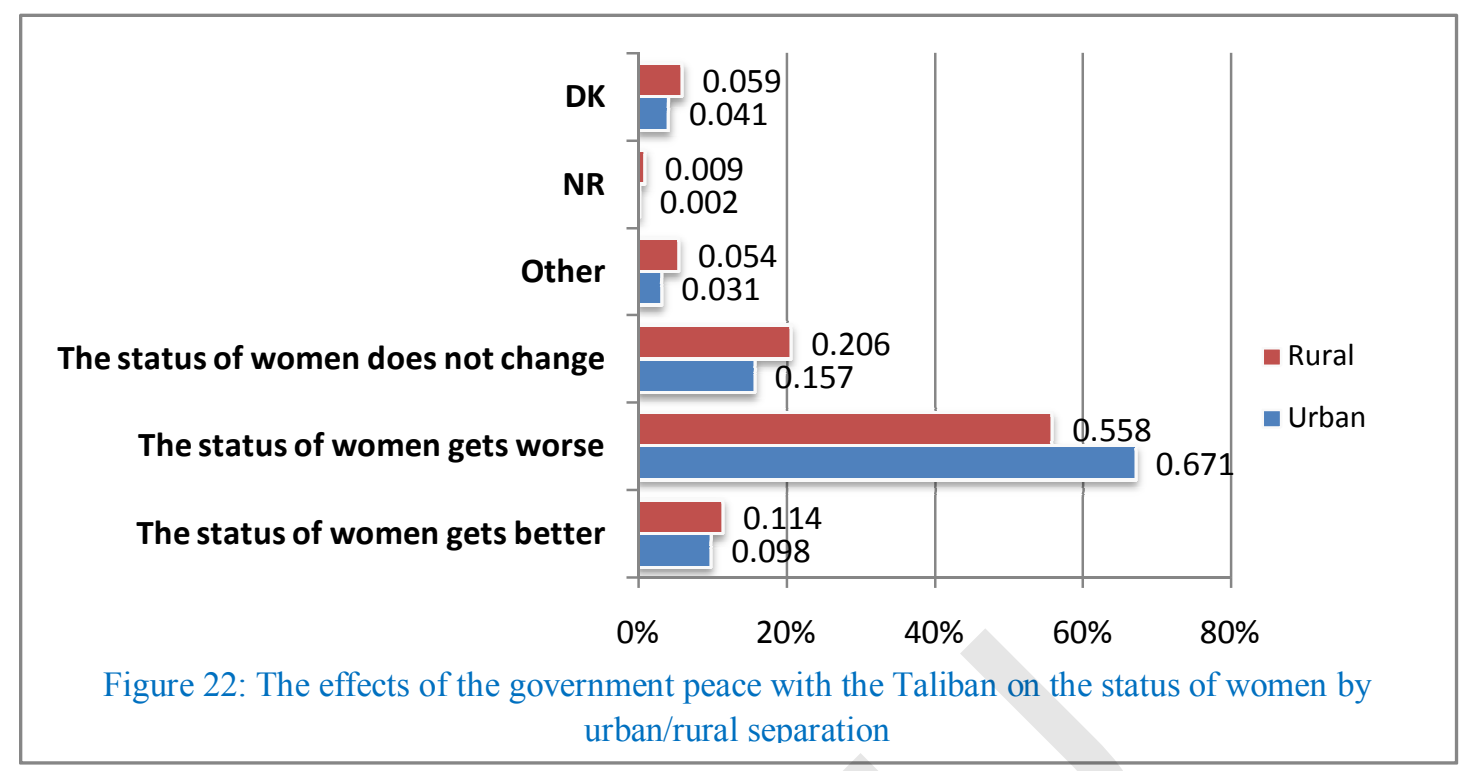

Amongst the interviewees who thought after peace with the Taliban, women situation gets better, a 22 year old woman from Zabul has commented: "Currently, women in insecure areas, particularly in Zabul province, cannot have jobs or go to school; after peacemaking, women's situation will get better". About the same matter, a 25 year old man from Kabul commented: "woman could gain all their legitimate rights after we have peace and security".

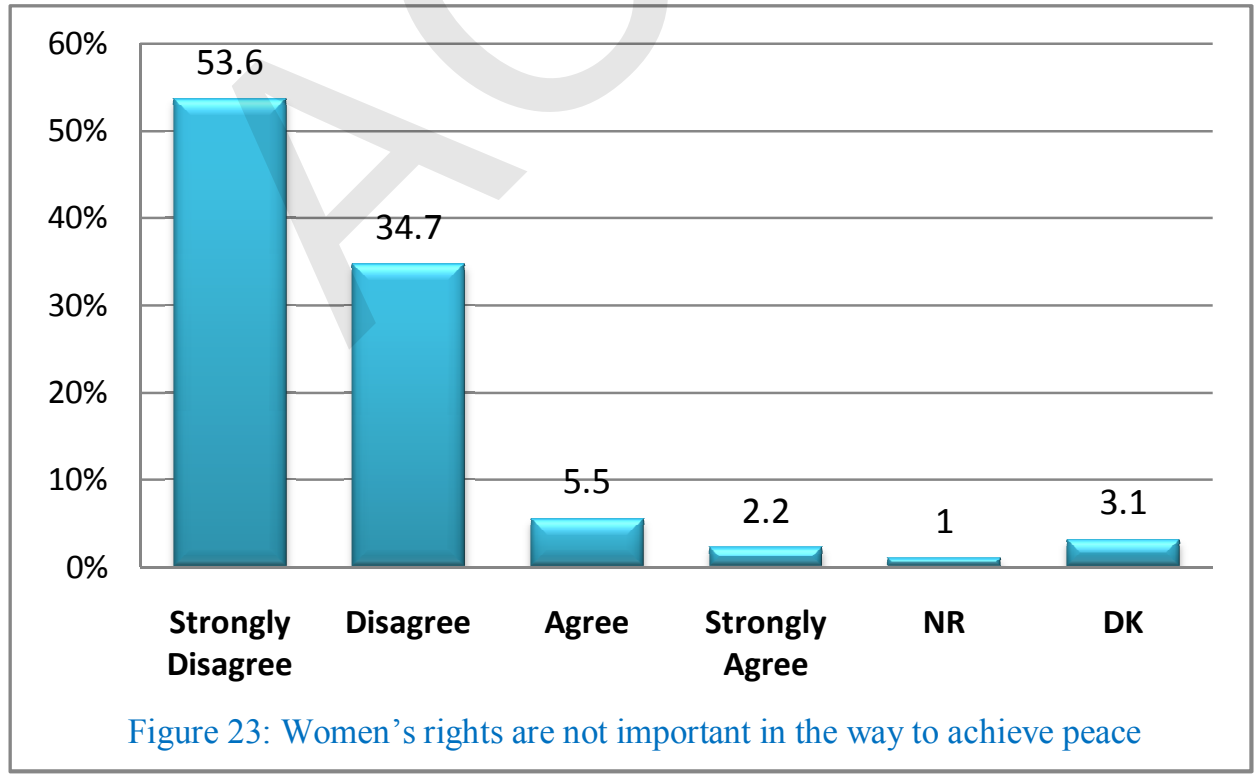

Figure 23 indicates the rates of "agree" or "disagree" opinions toward the statements "Women's rights are not important in the way to achieve peace". In total, $88.3 \%$ of the respondents were against this statement (53.6\% "strongly disagree", and $34.7 \%$ "disagree"). $7.7 \%$ of the respondents agree with the statement $(5.5 \%$ "agree", nearly $2 \%$ "strongly agree"). 
The respondents' viewpoints about the support and success of the peace talks

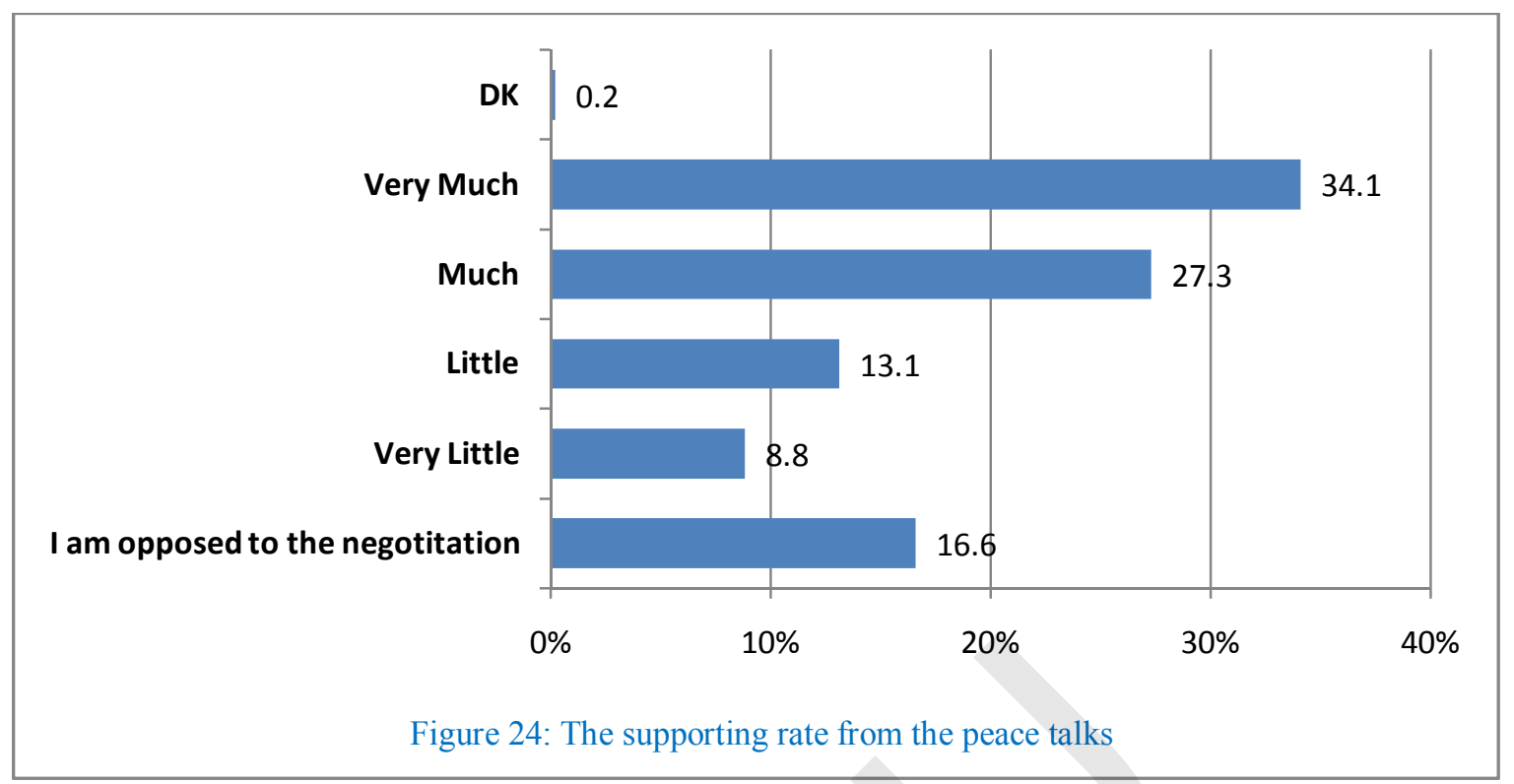

Figure 24 shows how much the respondents support peace talks. The majority of the respondents expressed their support for the peace talks by the extent of "very high" (34.1) and "high" (27.3). Almost $22 \%$ of the respondents selected the options "little" (13.1\%) and "very little" (8.8\%). Interestingly, $16.6 \%$ of the respondents said "I am against the talks".

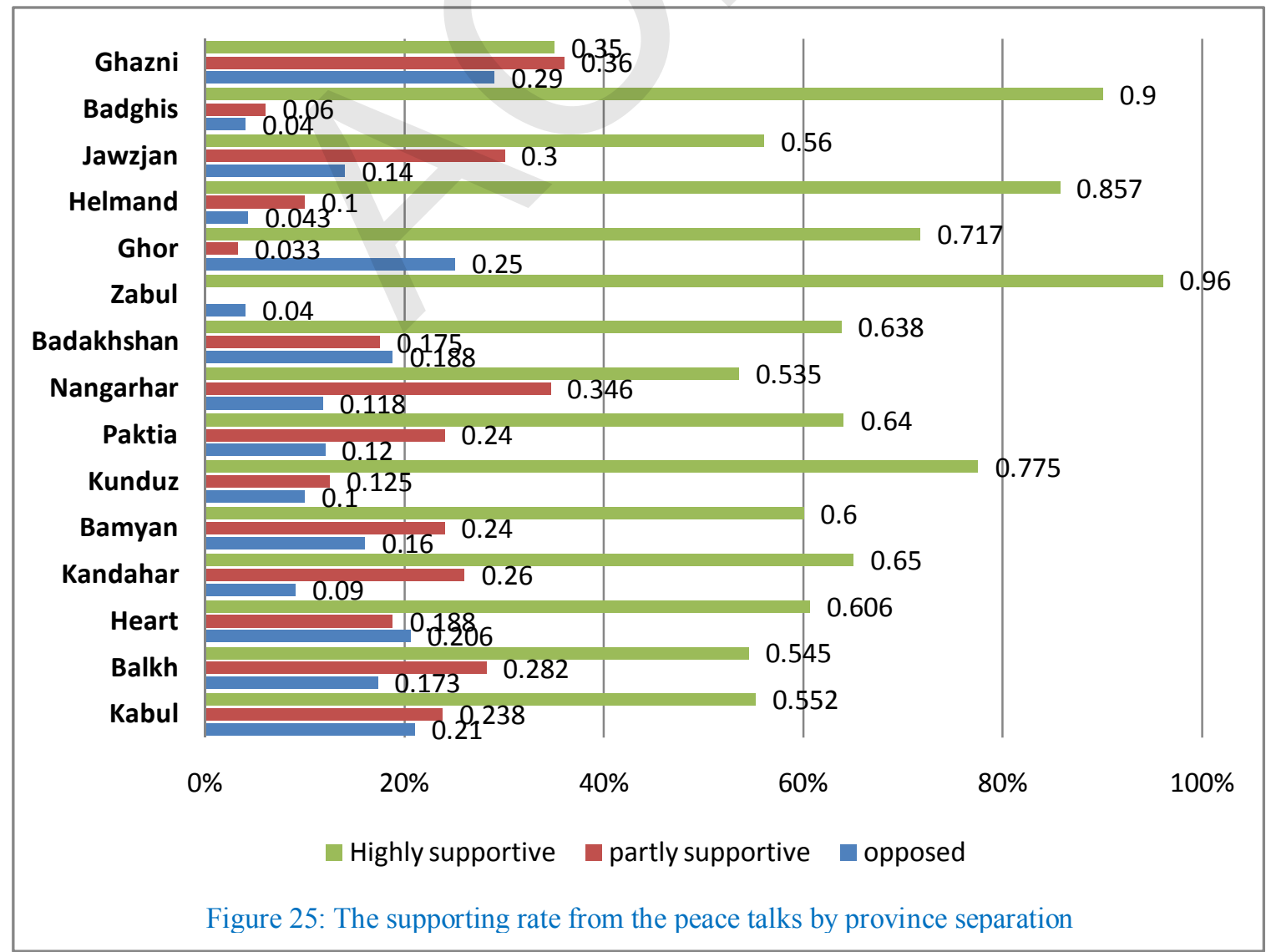


Figure 25 (previous page) shows the supporting rate of peace talks by each province. The majority of the respondents in 14 provinces support the talks in a "very high" level. Respondents from Zabul (96\%), Badghis (90\%), Helmand (almost $86 \%$ ), Kunduz (77.5\%), and Ghor (almost $72 \%$ ) present the highest amount of support for the peace talks. Only the respondents from the Ghazni province expressed less support (35\%). Most opposition to the peace process came from the respondents from Ghazni (29\%), Ghor (25\%), Kabul (21\%) and Herat (20\%) provinces.

Assessment of the process and results of peace talks

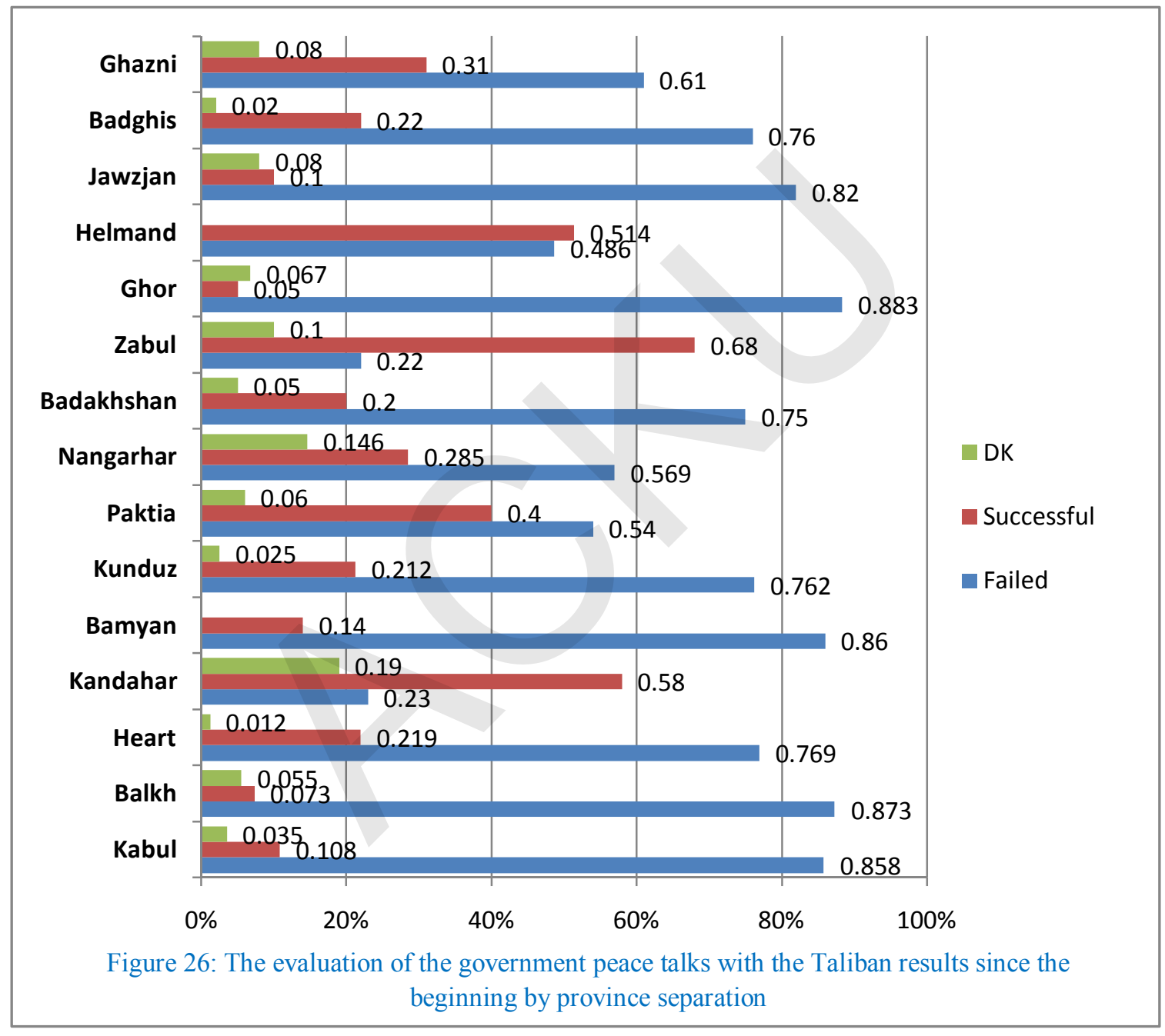

Figure 26 shows the evaluation about the results of the government peace talks with the Taliban by each province. Of 15 provinces covered by the survey, the majority of the respondents from provinces Kandahar (58\%), Zabul (68\%) and Helmand (51.4\%) stated that the government peace talks with the Taliban has been successful. But as it is shown in figure 24, apart from these 4 provinces, the majority of the respondents of all other provinces described the talks failed. Most of the respondents (above 70\%) in the provinces of Kabul, Balkh, Herat, Bamyan, Kunduz, Badakhshan, Ghor, Jawzjan and Badghis believe the talks failed. 
Table 4, shows the success rate of the National Unity Government in peace talks process. The mean success rate of this government calculated from all responses is $28.61 \%$.

Table 4: The success rate of the National Unity Government in peace talks

\begin{tabular}{|l|c|}
\hline The number of respondents & $\mathbf{1 5 4 0}$ \\
\hline The mean (of success rate) & 28.61 \\
\hline Low est rate (percentage) & 0 \\
\hline Highest rate (percentage) & 100 \\
\hline
\end{tabular}

Figure 27 shows the mean of the respondents scores given to the National Unity Government for its success rate in peace talks by each province. The respondents from the provinces Paktia (almost 55\%), Kandahar (almost 52\%) and Badghis $(41.5 \%)$ had the greatest hope for the success of the current government in peace talks. The respondents from the provinces Badakhshan (4\%), dawzjan (almost 7\%) and Bamyan (almost 7\%) had the least of optimism about the success of the National Unity Government.

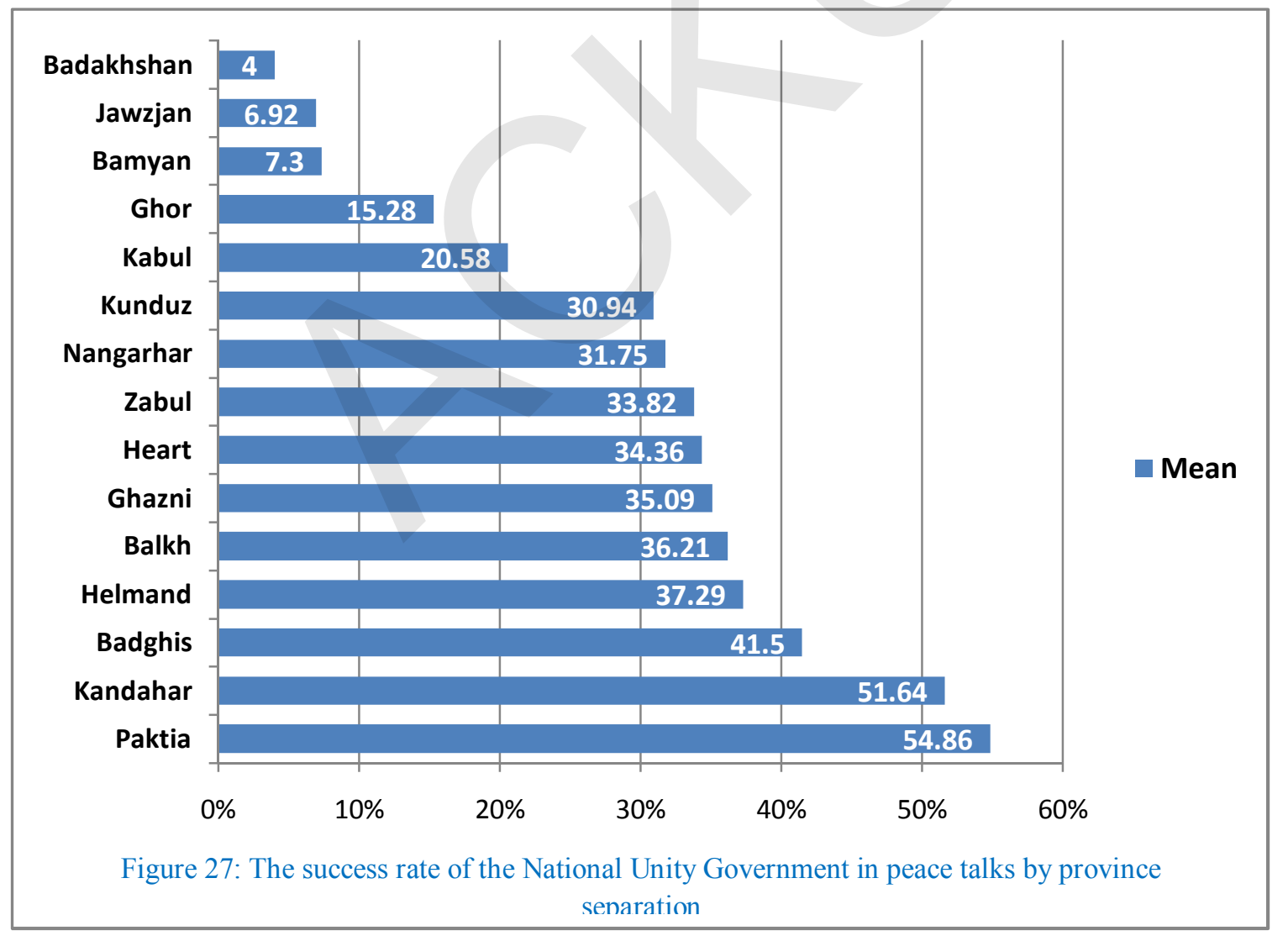

Figure 28 (next page) indicates the mean rate given to the National Unity Government for its success in peace process by each ethnic group. Pashtun respondents with $36.6 \%$ mean, has the highest optimism about the government success. This rate among Uzbeks respondents is about $28 \%$, among Tajiks is $27.31 \%$ 
and among Hazar as is $20.21 \%$. The lowest amount of optimism is from Turkmens by the mean of $11.55 \%$.

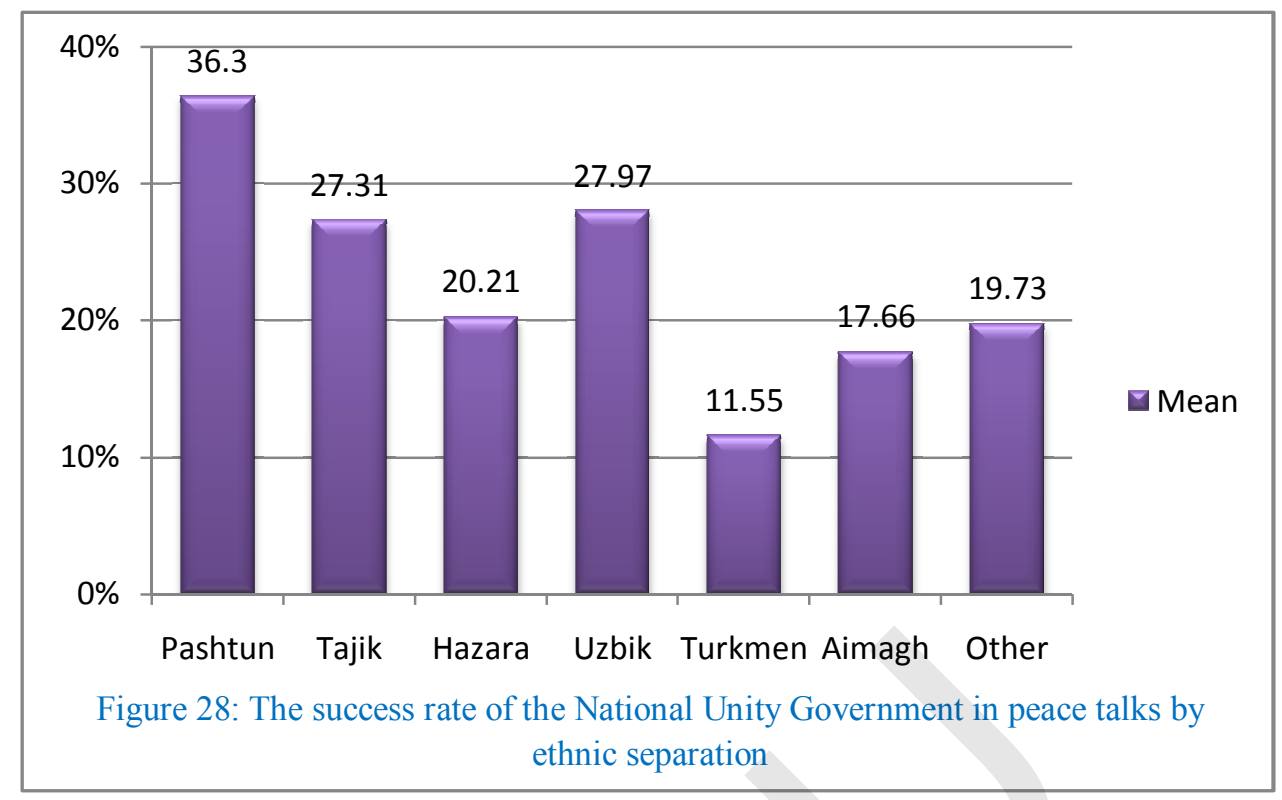

Figure 29 shows the respondents' concerns about the government peace talks with the Taliban. Almost $25 \%$ of the respondents said that their main concern is "compromising the people's rights". $20 \%$ of the respondents commented that their main concern was "failing to bring peace". The main concern of about $19 \%$ was "lack of transparency in peace talks". "Trampling women's rights" with $14.3 \%$ and "ignoring the Constitution" with $13.7 \%$ are the other important concerns of the respondents.

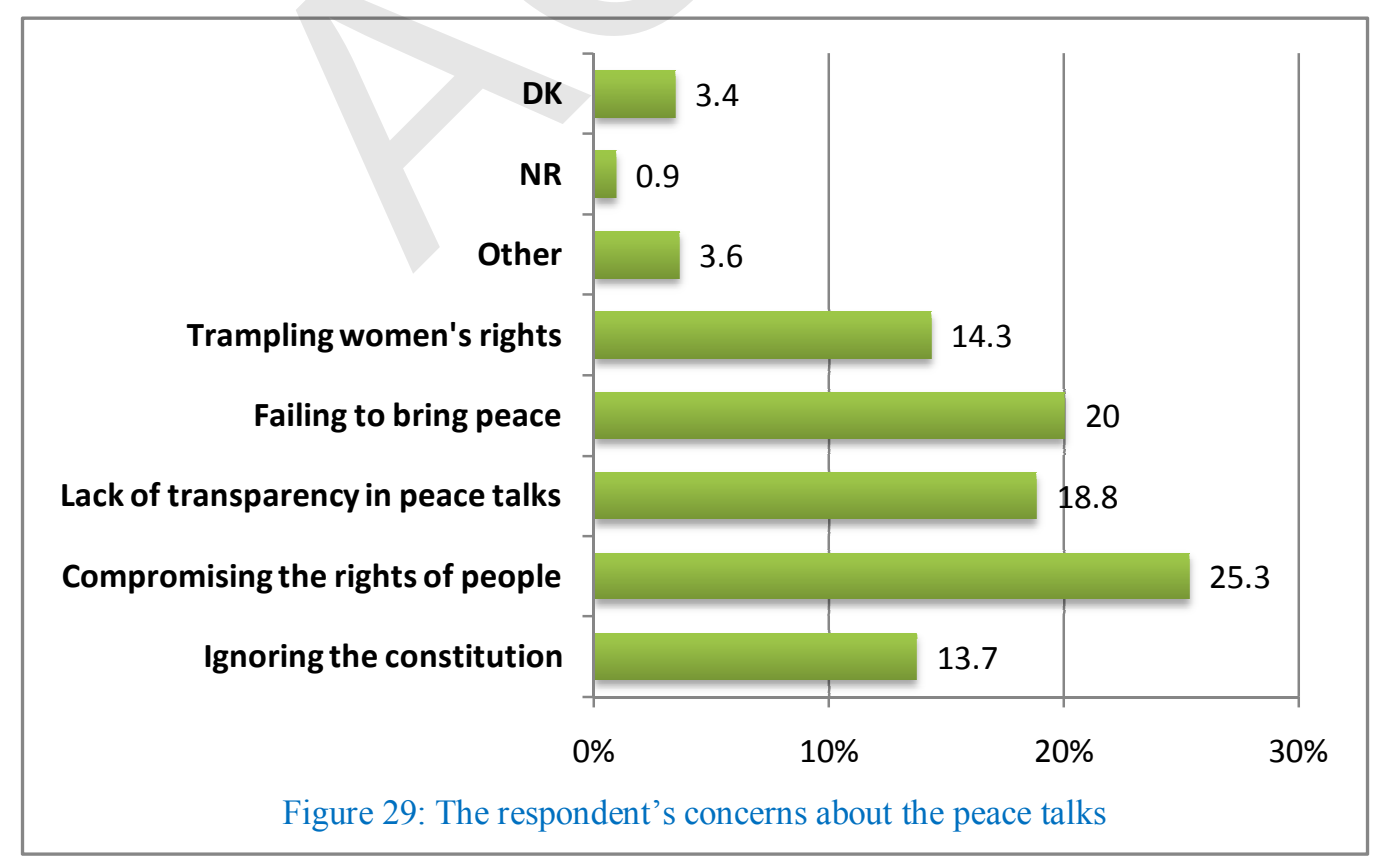

Figure 30 (next page) represents the respondents' opinions about the success and failure of the plan to attract and absorb the armed oppositions into the peace 
process. This was one of the most expensive Afghan government's efforts to bring peace. Almost $58 \%$ of the respondents believed that this plan has failed. About $17 \%$ thought it was successful and $15.3 \%$ responded they didn't know anything about it.

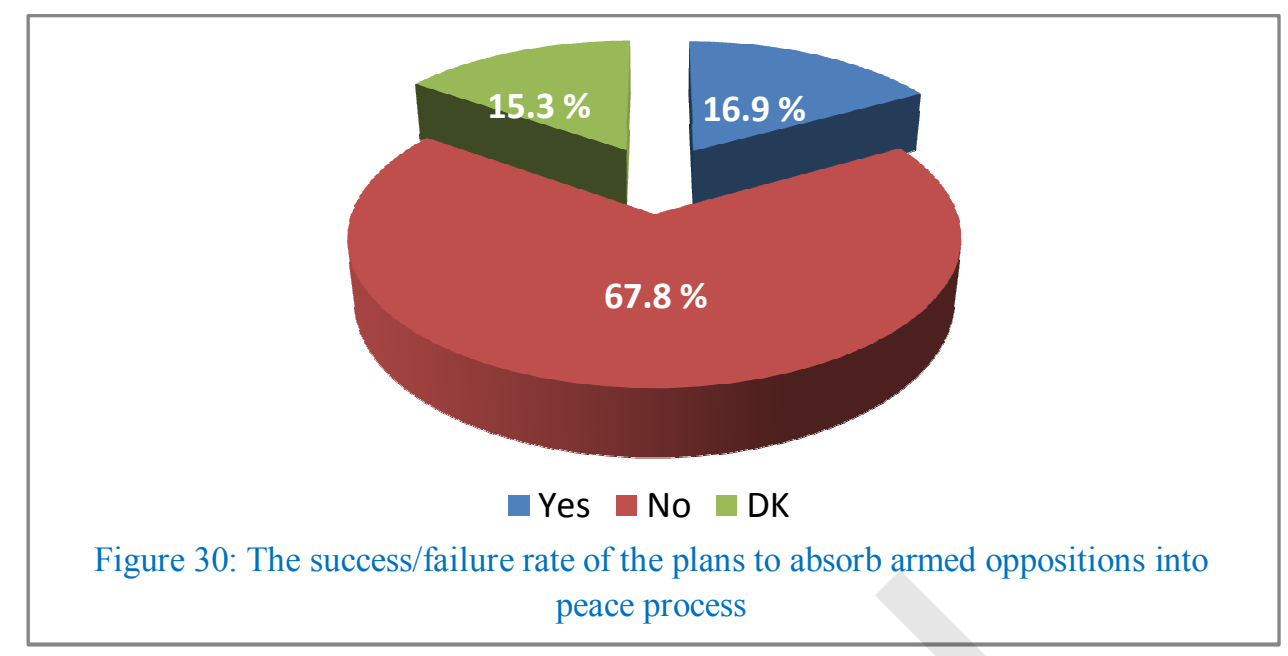

Figure 31 shows the success and failure of the plans to attract and absorb the armed oppositions into the peace process by each province. Almost $94 \%$ of the respondents from Helmand and Badakhshan, and $88 \%$ of the respondents from Zabul, believed these programs have not been successful in their provinces. $40 \%$ of the respondents from Ghor province, 36\% of the respondents from Bamyan province, and almost $34 \%$ of the respondents from Her at province believed that the program has been successful in their provinces. The response "I do not know" mostly was observed in Bamyan, Balkh and Nangarhar provinces.

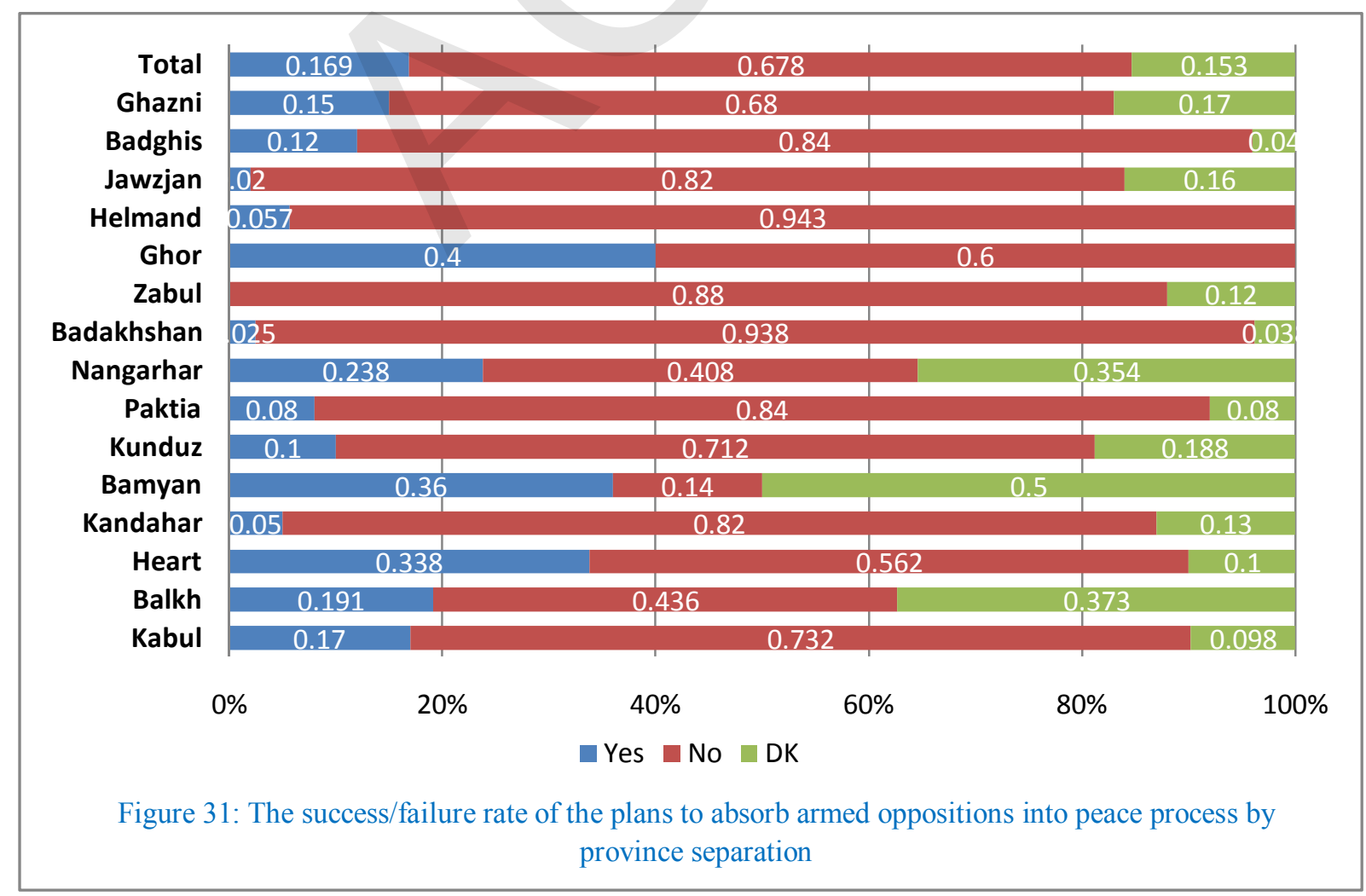




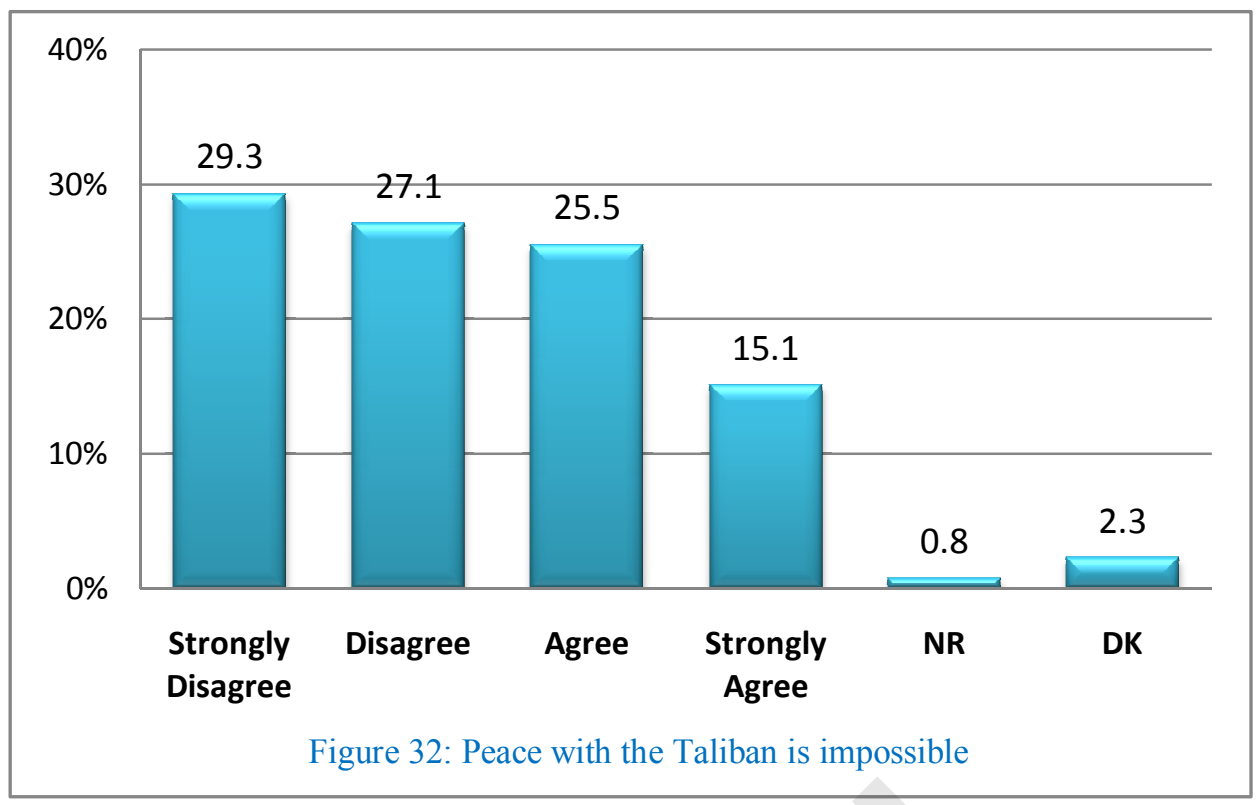

Figure 32 shows the respondents' agreement or disagreement with the statement "Peace with the Taliban is impossible". In total, $56.4 \%$ of the respondents were against the statement (29.3\% "strongly disagree" and $27.1 \%$ "disagree"). $40.6 \%$ of the respondents were agreed with the statement (25.5\% "agree" and almost $15 \%$ "strongly agree").

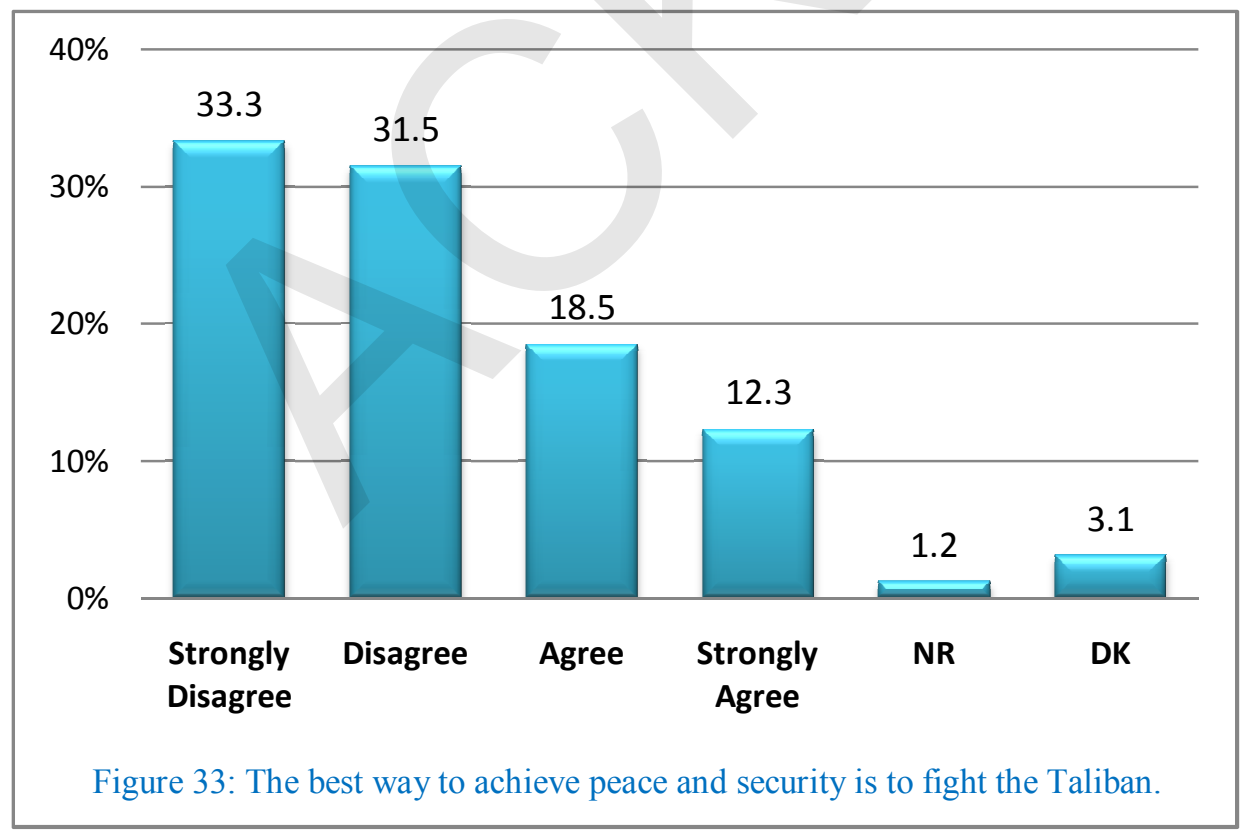

Figure 33 indicated the rate of agreement and disagreement with the statement "The best way to achieve peace and security is to fight the Taliban". Almost 64 percent of the respondents were against the statement (33.3\% "strongly disagree" and $31.5 \%$ "disagree"). It means that $64 \%$ of the respondents believe that fighting the Taliban will not help to bring peace and security. In contrast with this view, $31 \%$ of the respondents agreed that fighting the Taliban is the best way to bring peace and security (18.5\% "agree" and almost $12 \%$ "strongly agree"). 


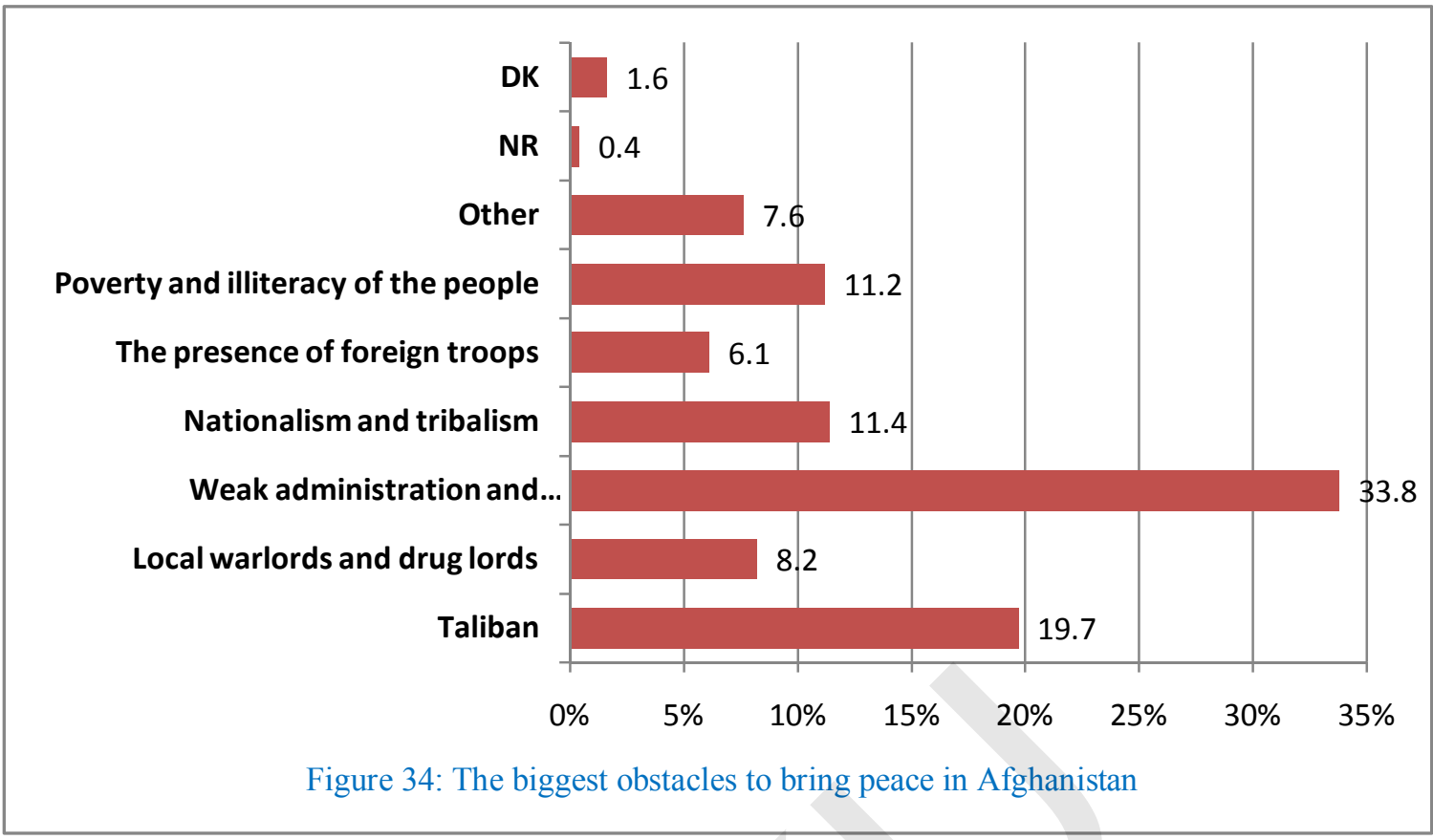

Figure 34 shows the biggest obstacles to bring peace in Afghanistan. Of the respondents' viewpoint, "weak administration and widespread corruption" is the greatest obstacle to peace by almost $34 \%$ rate. About $20 \%$ of the respondent believed that "the Taliban" are the main obstacle for peace. 11.4\% thought the biggest obstacle is "nationalism and tribalism". About $6 \%$ see "the presence of for eign forces" as the most important problem for peace process while this cause is located at the low est place in respondents' choices.

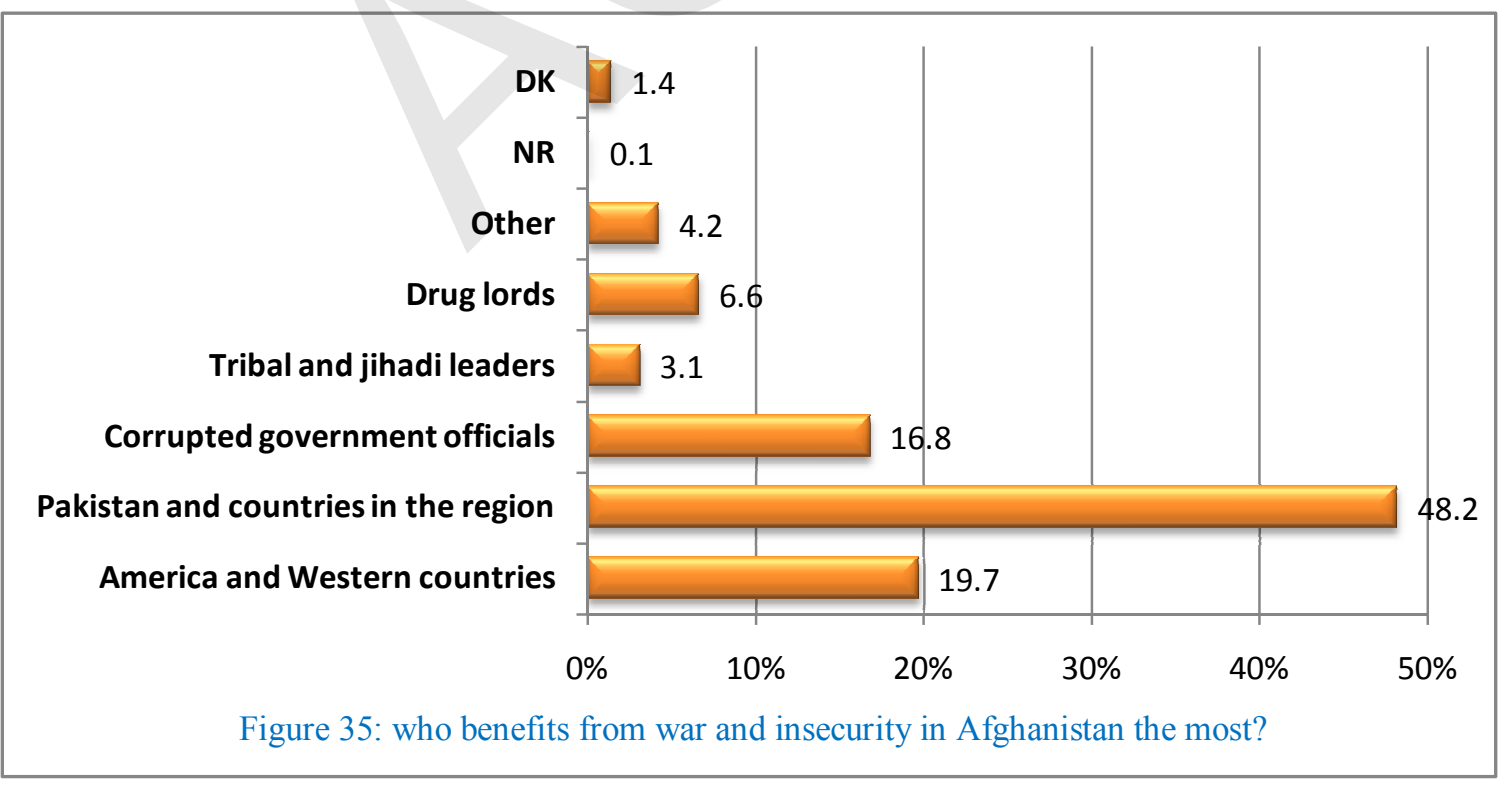

Figure 35 shows those who benefit the most from the war and insecurity in Afghanistan. Almost $48 \%$ of the respondents believe that "Pakistan and the countries in the region" benefit from the war in Afghanistan more than others. "America and 
the West" with $20 \%$, "corrupted officials" with nearly $17 \%$, and "drug lords" with $6.6 \%$, respectively are next in the rank.

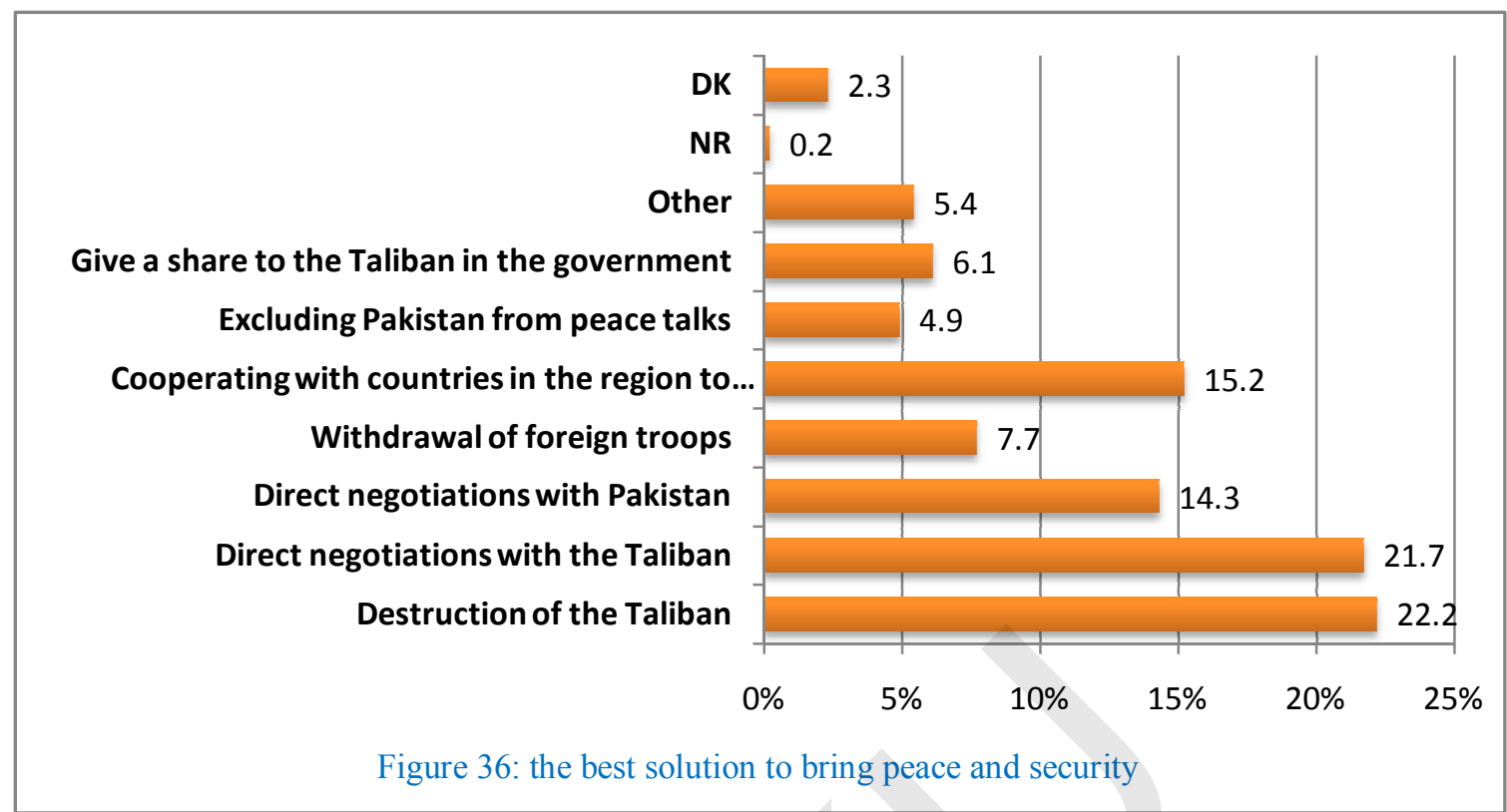

Figure 36 shows the best solution to achieve peace and security in Afghanistan. Almost $22 \%$ of the respondents stated that "The destruction of the Taliban" is the best possible solution. $21.7 \%$ of the respondents believed that there should be a "direct negotiation with the Taliban". Almost $15 \%$ of the respondents thought that the best way is "Cooperating with countries in the region to promote peace talks". Also, "direct negotiation with Pakistan" (14.3\%) and "withdrawal of foreign troops" (7.7\%) are respectively the next selected solution by the respondents.

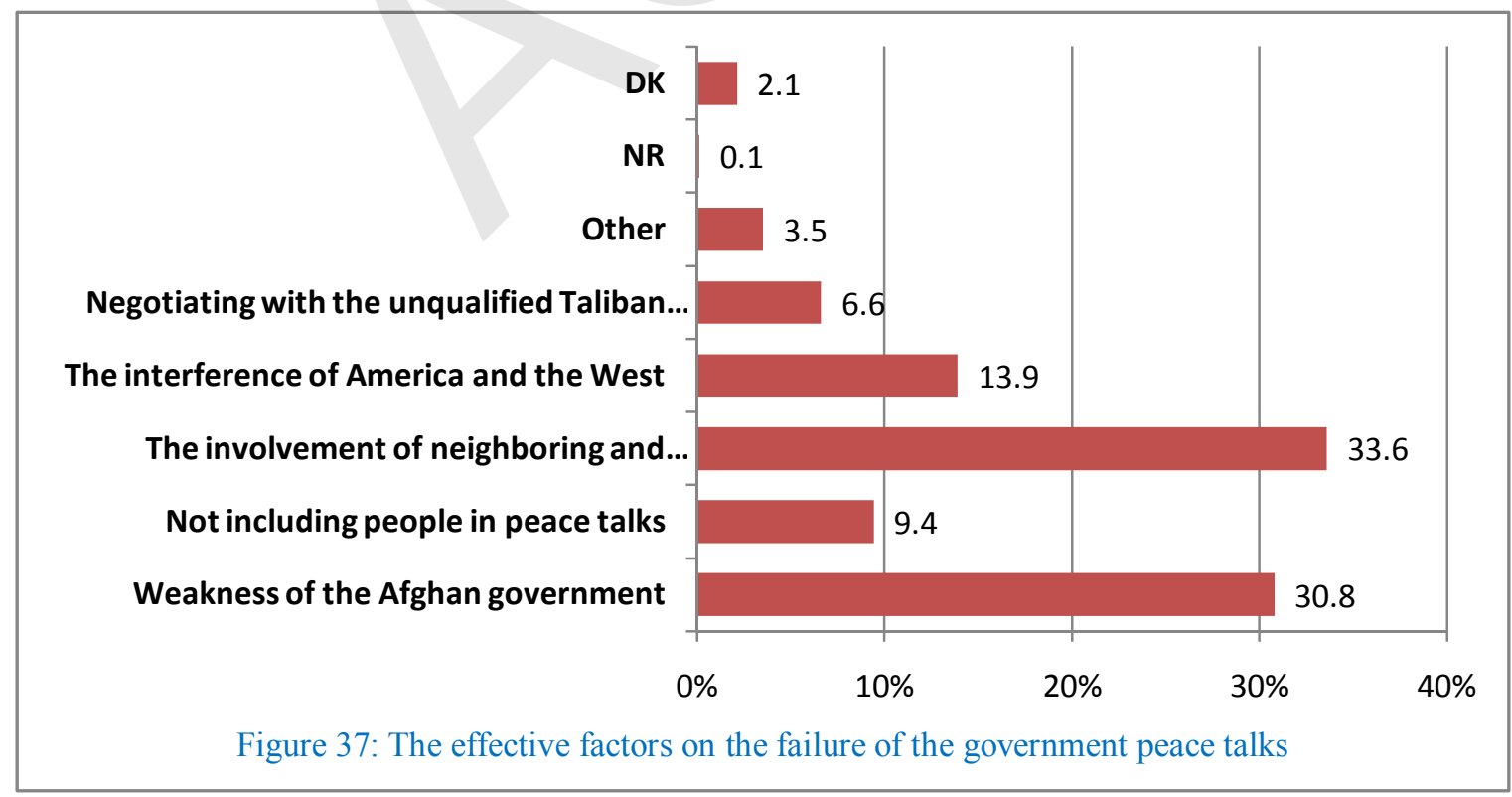

Figure 37 shows the factors which affected on the failure of the government peace talks with the Taliban so far. $33.6 \%$ of the respondents believed the reason is "The 
involvement of neighboring and regional countries". Almost $31 \%$ believed that the failure caused by "weakness of the Afghan government". "The interference of America and the West" with almost $14 \%$ and "not including people in peace talks" with $9.4 \%$ are the next reasons given as a cause to the failure of the talks.

\section{Assessment of the forces affecting the success of peace talks}

Certainly, bringing peace in Afghanistan requires the cooperation and help from various forces. The range of the influential forces in establishing peace in Afghanistan, starts from the people and continues to neighboring countries and world powers. In this part of the survey, the results focused on this matter are presented.

\section{Role of the people}

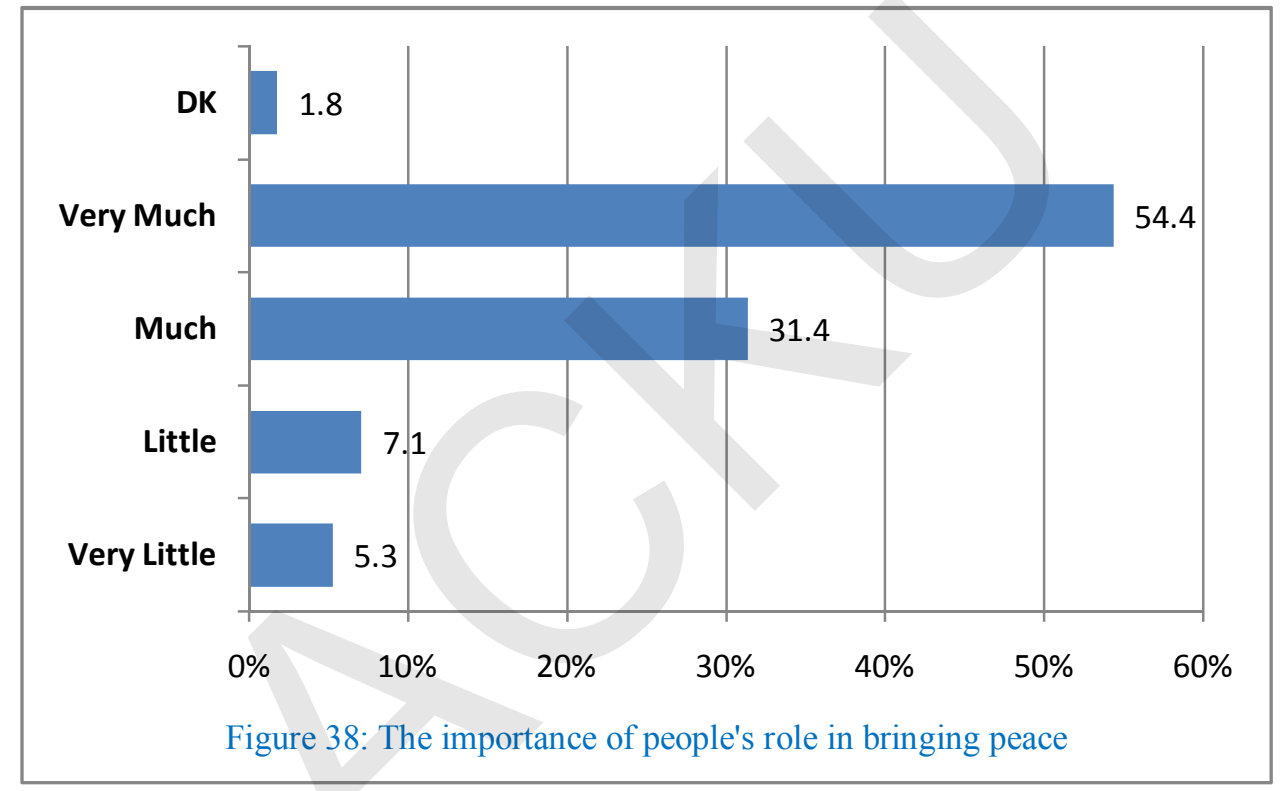

As figure 38 shows, the respondents in gener al believed that the role of people in establishing peace is very important. Almost $86 \%$ of the respondents described peoples' role "very high" (54.4\%) and "high" (31.4\%). 12.4\% of the respondents selected the options "very little" (5.3\%) and "little" (7.1\%).

\section{The impact of various local institutions and groups on peace talks}

\section{High Peace Council}

Regardless of judging the success or failure, the Afghan government has made great efforts in order to bring peace. One was the establishment of the High Peace Council in October 2010. The necessity of such council was raised during the Consultative Peace Jirga which was held in Kabul. Almost 1,500 tribal elders participated in the Jirga and it was aimed to seek a solution to the current conflict in Afghanistan. One of the main suggestions in this Jiga was to establish a peace council. 


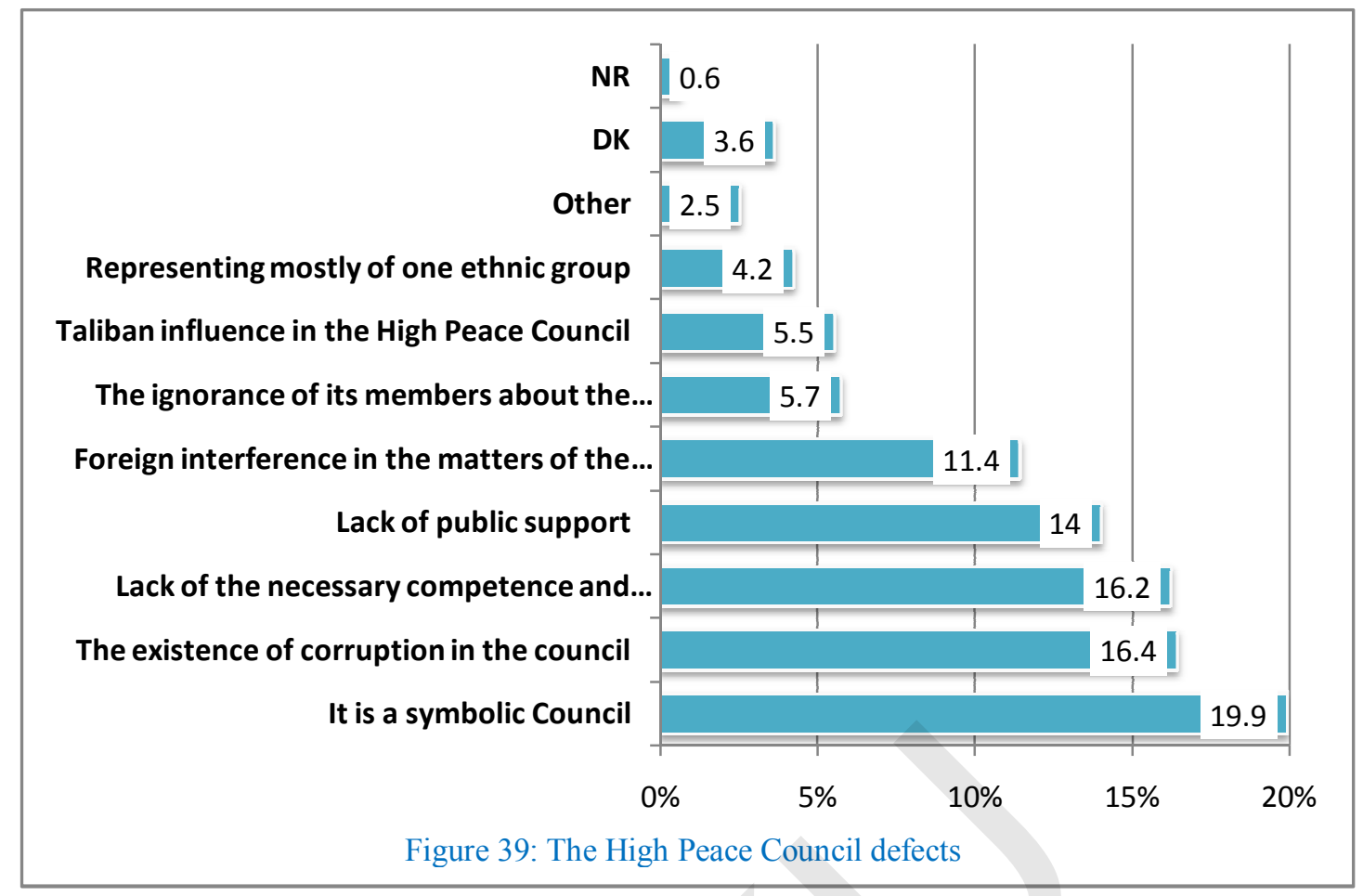

Figure 39 indicates the ranges of respondents' opinions about the most important weaknesses of the High Peace Council. As it is shown in the figure, the majority of the respondents (19.9\%) believed that the High Peace Council is "a symbolic council". With close results, "corruption in the council" (16.4\%) and "lack of the necessary competence and independence in the council" (16.2\%) are the other defects of the High Peace Council with the highest figures in the poll; they are followed by "lack of public support" (11.4\%) and "foreigners' interference with the Council issues". In total, almost $78 \%$ of the respondents chose the five answers mentioned above. Also $5.7 \%$ of the respondents believed that "the High Peace Council does not know how to negotiate with the Taliban" and 5.5\% of them consider "the Taliban's influence in the Council" as its main weakness.

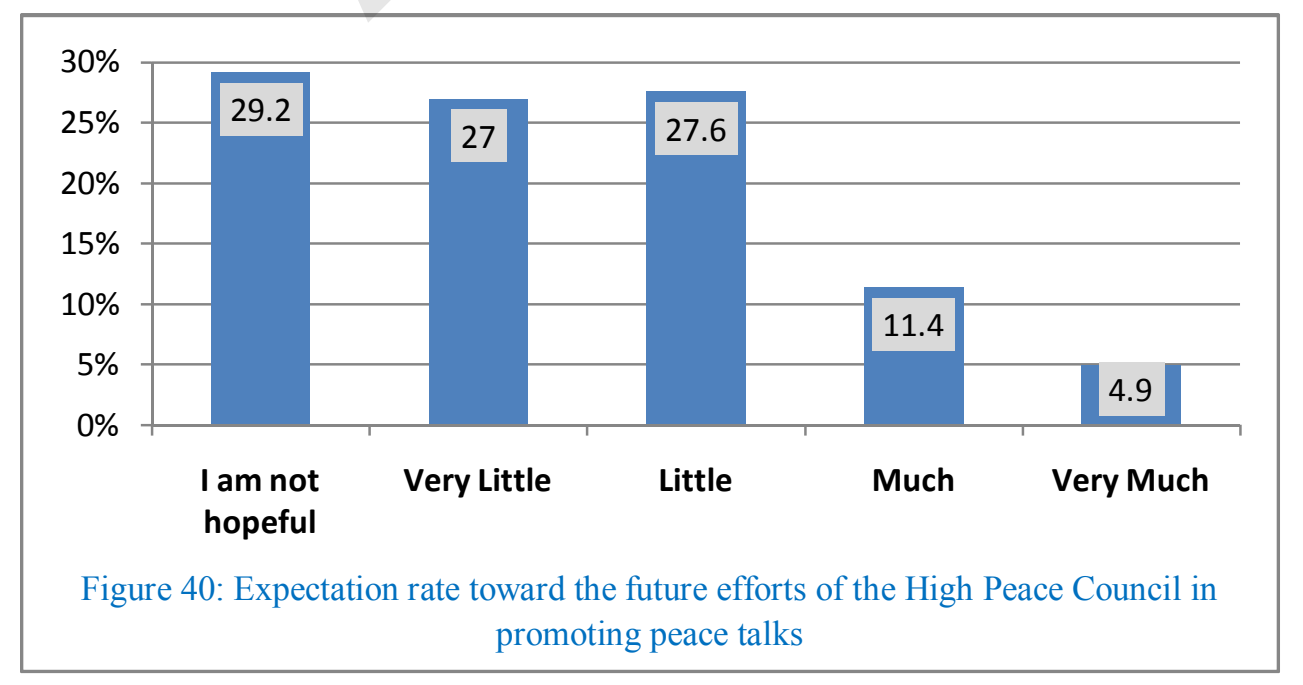

Another question was designed to evaluate to what extent the peace council has 
been successful in the matter of peace talks. The result as is shown in the figure 40 (previous page), indicates that $29.2 \%$ of the respondents has no hope for the effectiveness of future efforts by the High Peace Council in promoting peace talks. Accordingly, almost $55 \%$ of the respondents have "little" (27.6\%) and "very little" $(27 \%)$ hope for its success. The poll has shown only a small portion of the interviews have high amount of hope about the success of the High Peace Council (11.4\% "high" and $4.9 \%$ "very high").

Government officials and consensus about peace talks with Taliban

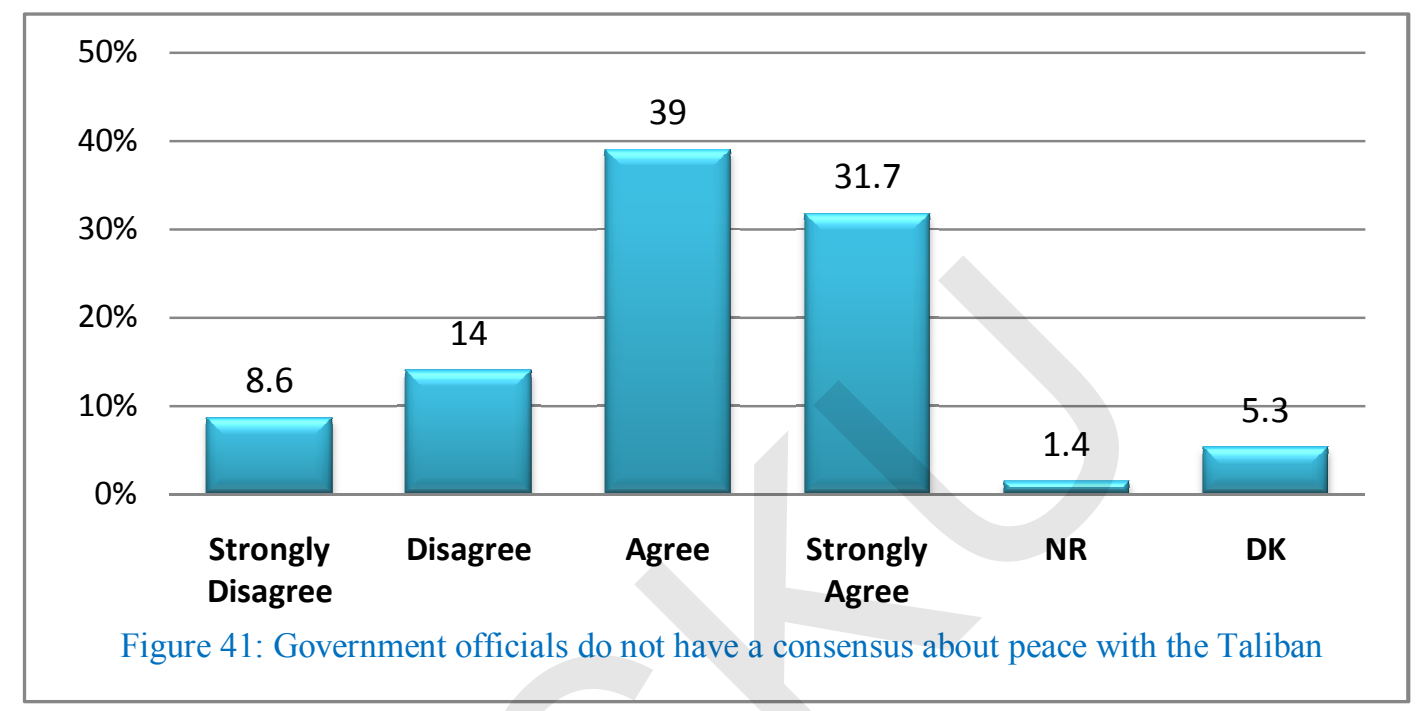

The figure 41 shows the agr eement or disagr eement of people with the statement "government officials do not have a consensus about peace with the Taliban". $70.7 \%$ of the respondents were "strongly agree" (31.7\%) and "agree" (39\%) with the mentioned statements. $14 \%$ of the respondents "disagree" with the statement and $8.6 \%$ "strongly disagree" with it.

The role of various local institutions in the success of peace talks

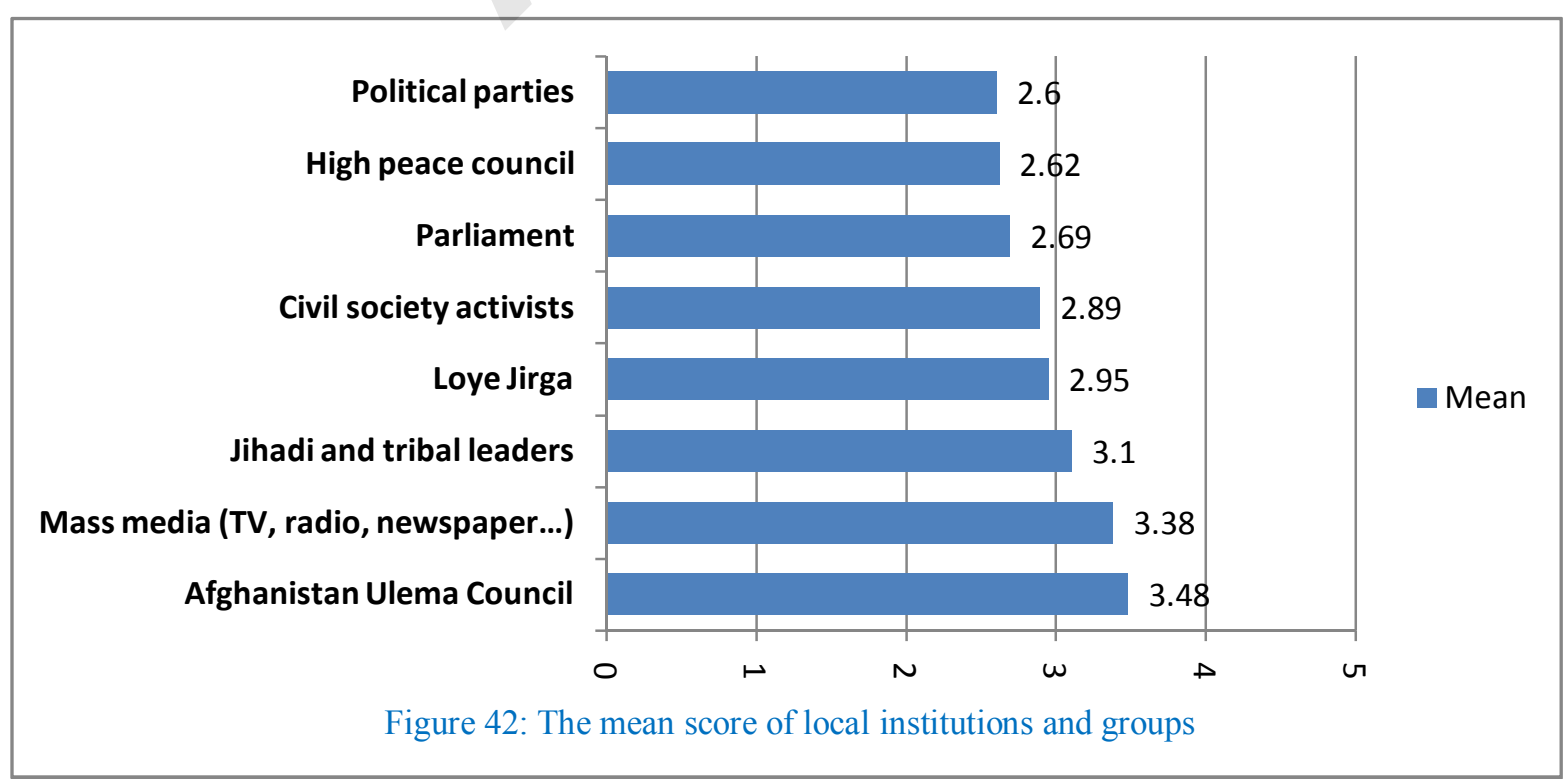


Figure 42 (previous page) shows the mean score of effectiveness of each local institutions and groups given by respondents. In this question, respondents were asked to rate the effectiveness of each institution and group in peace talks from 1 to 5. This figure shows that from the perspective of respondents, Afghanistan Ulema Council (3.48) could have the highest impact on the success of peace talks. Mass media such as TV, radio and newspapers (3.38), jihadi and tribal leaders (3.1) rank second and third, respectively. The respondents believed that political parties (2.6) and High Peace Council (2.62) have the minimal impact on the matter of peace talks.

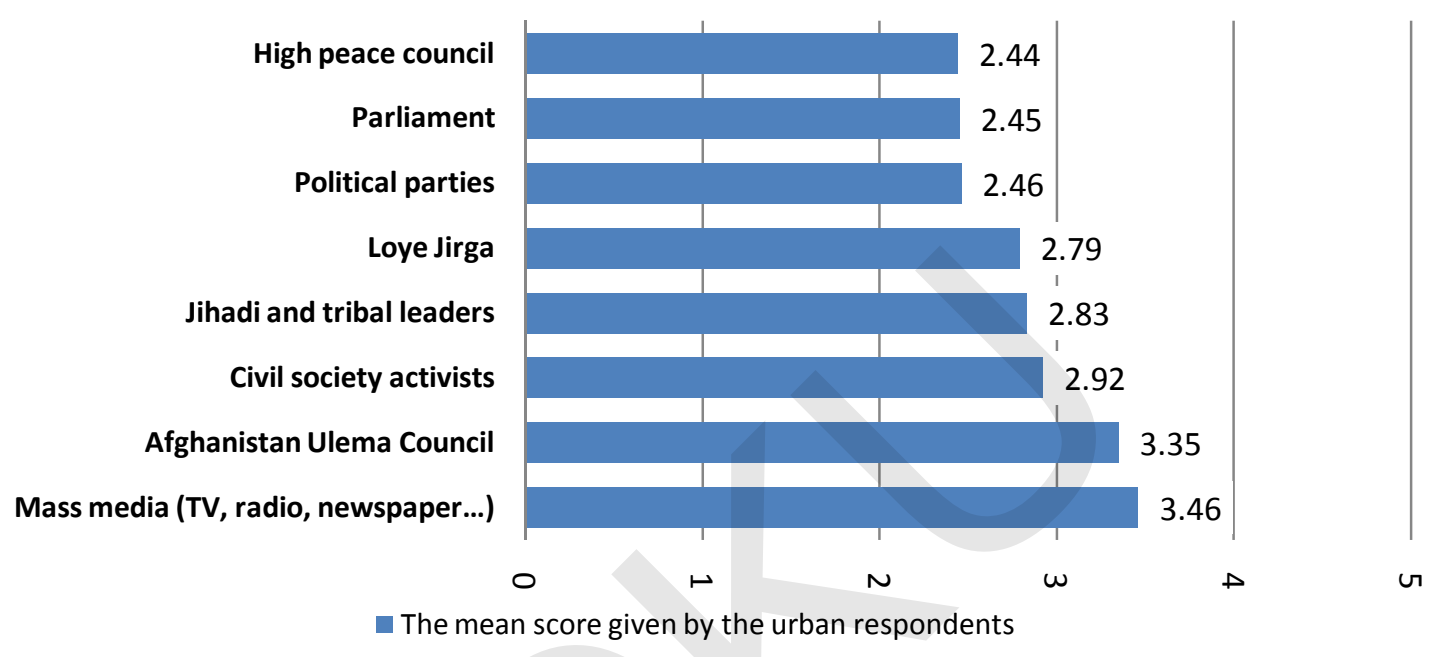

Figure 43: The average score of the local institutions and groups from perspective of urban respondents

There are serious differ ences between viewpoints of urban and rural respondents about the impact of local institutions and groups on peace talks. From the perspective of urban respondents, mass media (3.46), Afghanistan Ulema Council (3.35), and civil society activists (2.92) have the highest effectiveness, and the High Peace Council has the lowest (2.44). (Figure 43)

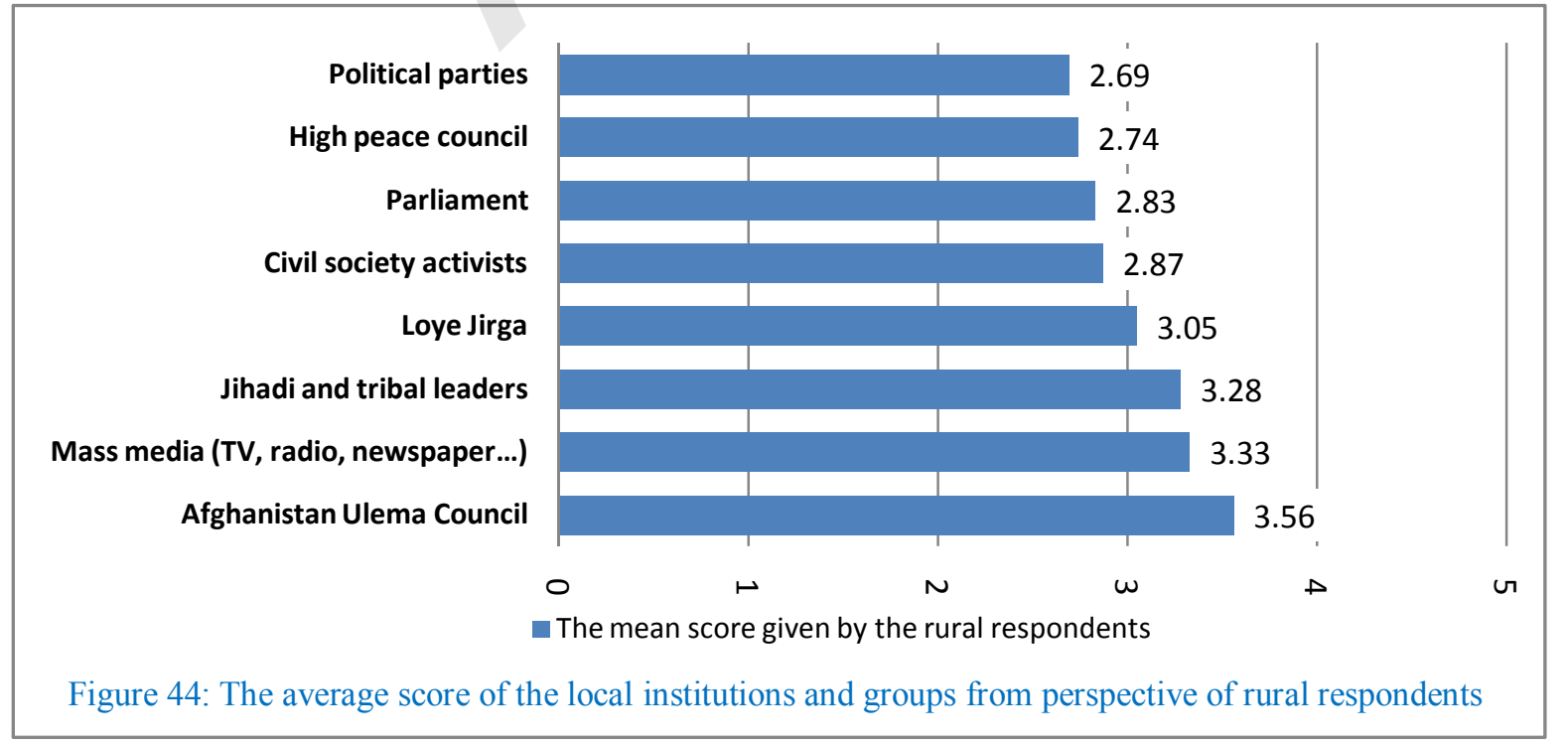


Accordingly, as it is shown in figure 44 (previous page), rural respondents in this poll believe that Afghanistan Ulema Council (3.56), mass media (3.33) and jihadi and tribal leaders (3.28), respectively have the highest level of effectiveness. Also from their point of view, High Peace Council (2.74) and political parties (2.69) located at the bottom of the ranking.

The impact of regional and international factors in the success of peace talks

Of the most important reason the Taliban suggests for its campaign, is the presence of foreign forces in Afghanistan. This group uses the word "occupation" to describe the foreign troops' presence and it is supported by some of Afghanistan neighboring countries.

Figure 45 shows respondents opinions about the issue of for eign forces presence and its relation to peace or exacerbation of insecurity. As it is shown, a staggering discrepancy can be observed in the views. $43.6 \%$ of the interviewees stated that the presence of these forces has helped bringing peace by the levels of "very high" $(19 \%)$ and "high" (24.6\%). Accordingly, 29.5\% of respondent's responses were "little" $(17.5 \%)$ and "very little" (12\%). An impressive figure here is that almost $27 \%$ of the interviewees stated that presence of foreign forces in Afghanistan is causing more insecurity.

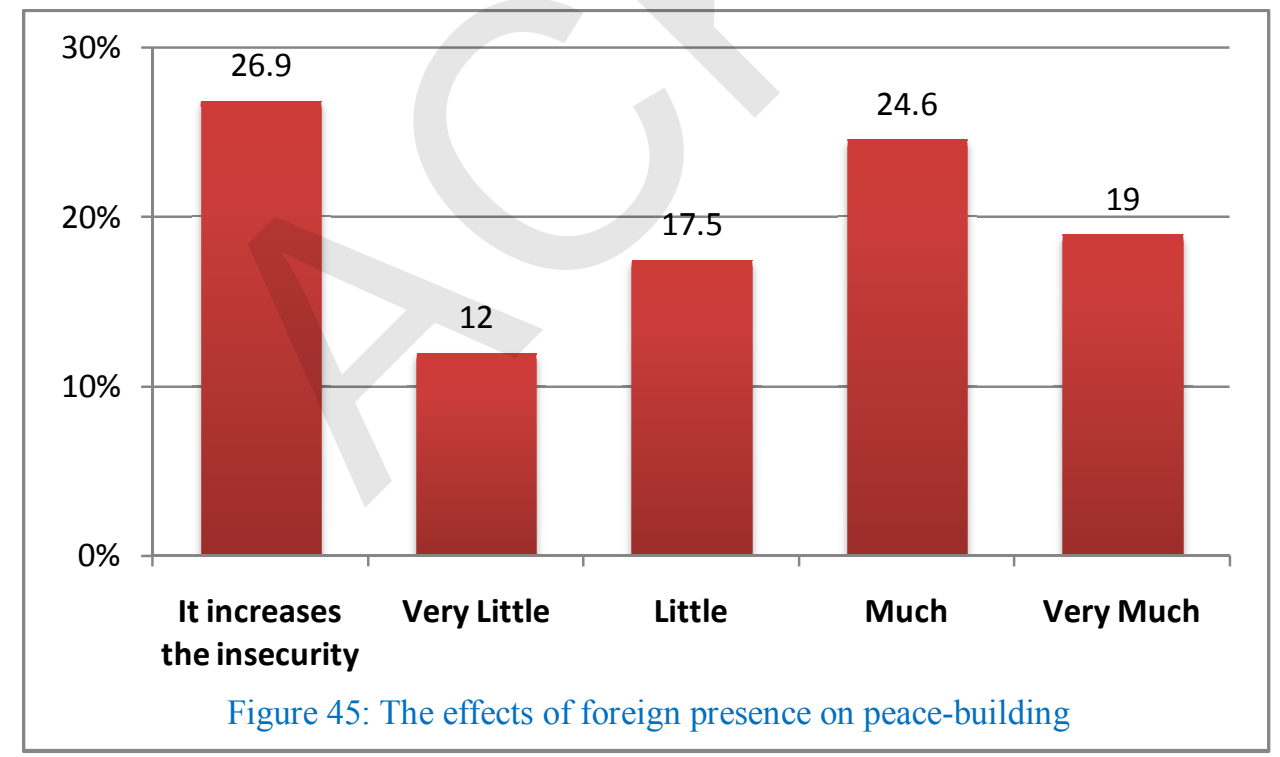

Figure 46 (next page) indicates the respondents' opinions about Pakistan's role in peace talks. $56.3 \%$ of the respondents "disagree" $(27.7 \%)$ and "strongly disagree" $(28.6 \%)$ with the statement "The Afghan government can promote peace talks without Pakistan's cooperation." According to the survey results, $40 \%$ of the respondents agree that afghan government can carry on with peace negotiations without the presence of Pakistan ("agree": $15.2 \%$ and "strongly agr ee": $24.4 \%$ ). 3.5\% of the respondents chose the option "I don't know" at the questionnaire and $0.6 \%$ did not answer this question. 


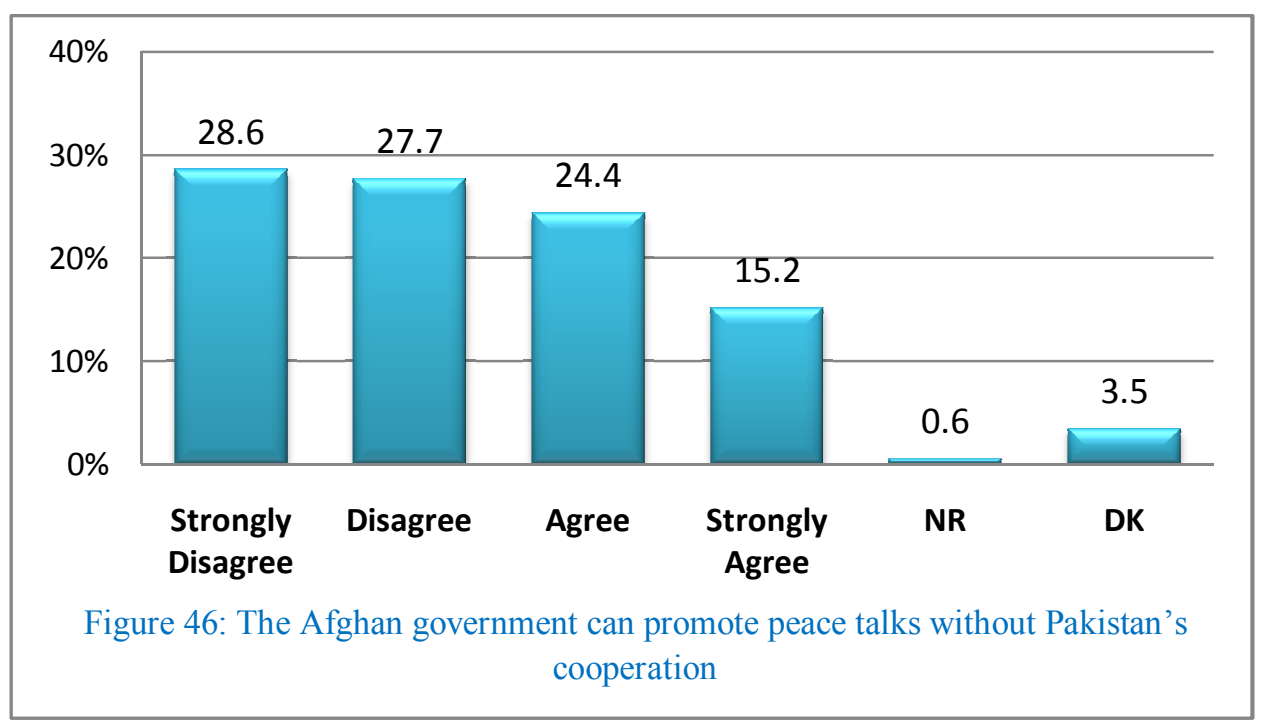

Figure 47 shows the mean score of effectiveness of some countries and the international coalition on the success of peace talks. The respondents were asked to score each one of them from 1 to 5 .

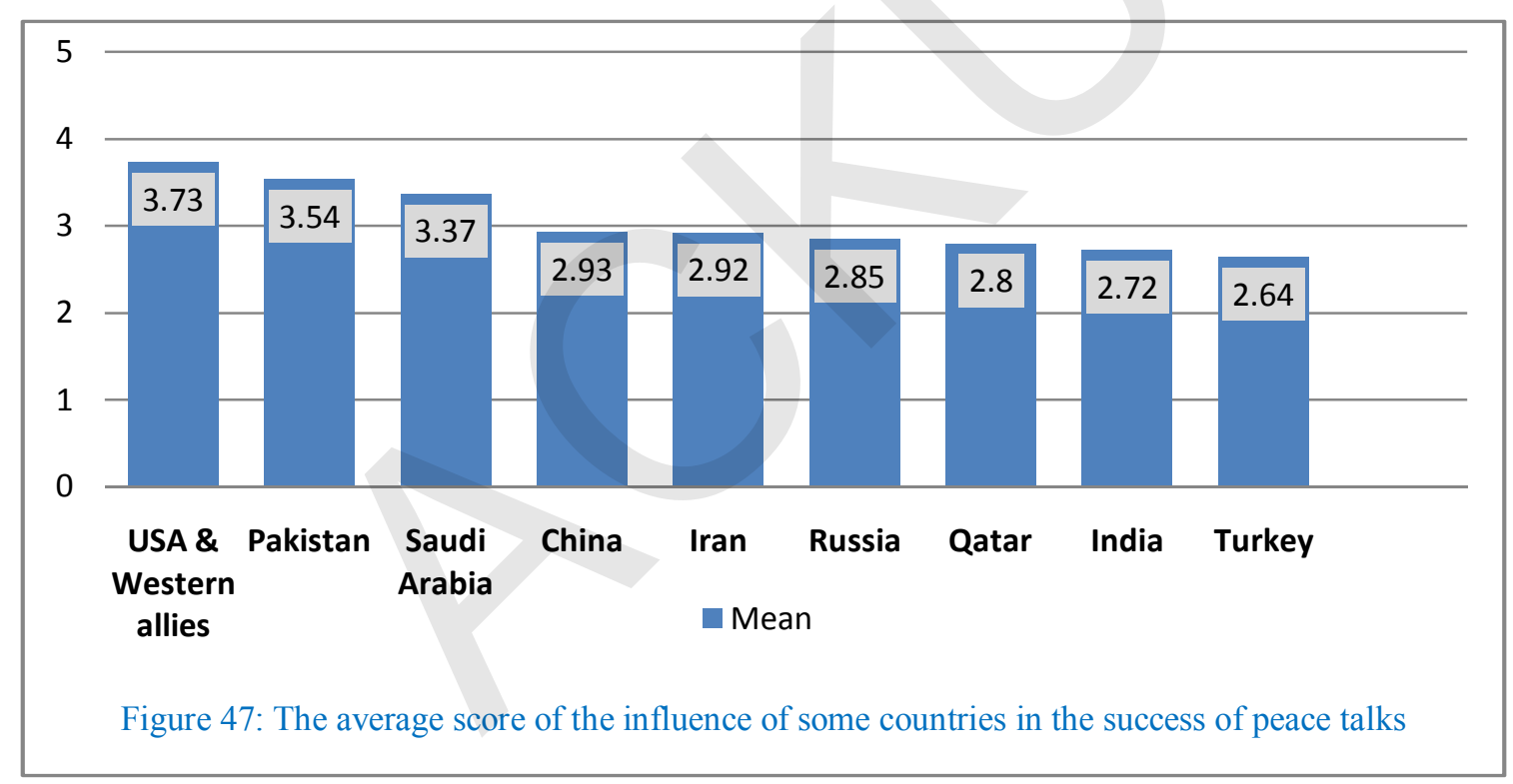

As it can be observed from Figure 47, America and its Western allies (3.73), Pakistan (3.54), Saudi Arabia (3.37) respectively has the highest scores. And the lowest scores are given to India (2.72) and Turkey (2.64).

\section{Why peace with the Taliban?}

At the end of the survey questionnaire, there was an "open question" which was aimed to assess the respondents' reasons for being agreed or disagreed with the government peace talk with the Taliban. As it is shown in Figure 48, the vast majority of the respondents are in favor of Afghan government peace talks with the Taliban $(81 \%)$. Most of the reasons given by people, who agr ee with peace talks, were related to the issue of insecurity and economic problems. 
To answer this question, A 48 year old man from Kabul said: "The people are tired of war and insecurity." The majority of responses emphasized on the point that currently, peace and security are the most urgent needs of Afghan people. A large number of the respondents argued that the government peace with the Taliban (the main cause of insecurity in Afghanistan) will make "the weak business" better. A 40 year old woman from Ghazni province about the issue said, "The people of Afghanistan are tired of war. Unemployment and corruption has increased and the situation requires peacemaking".

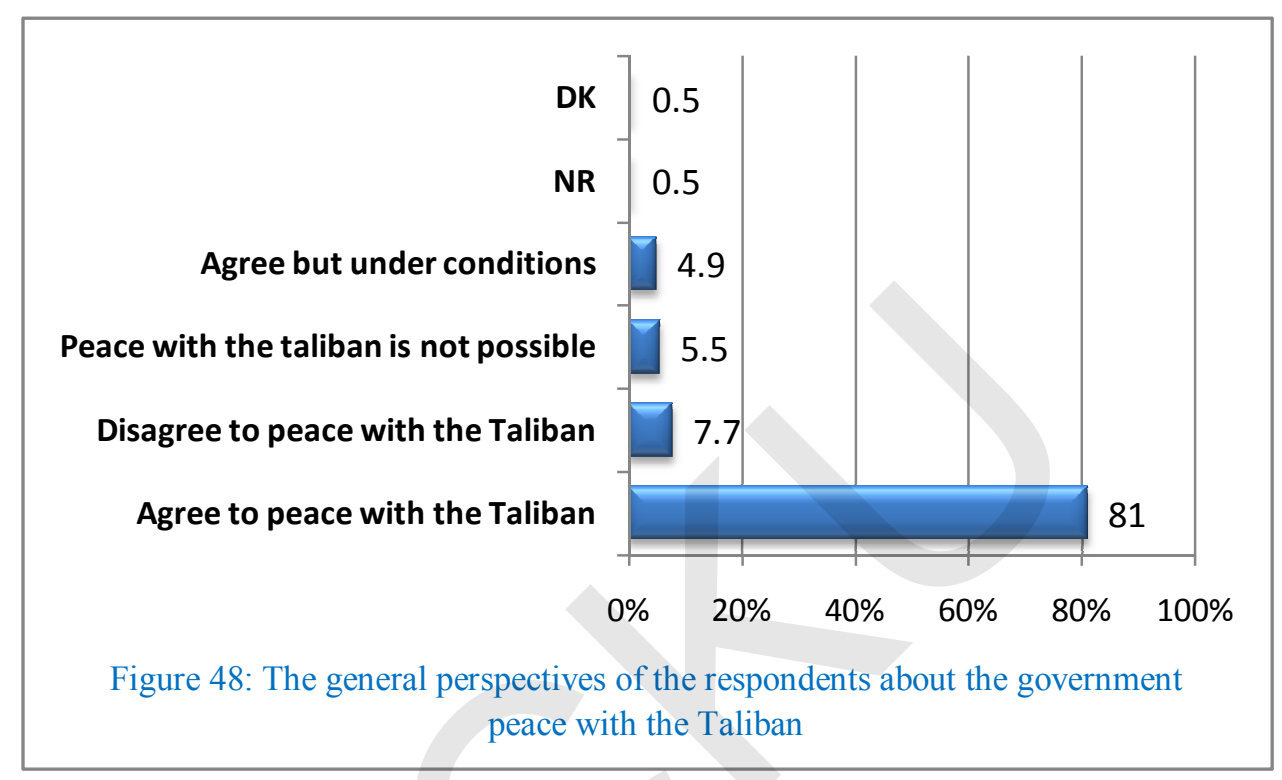

Also a 34 year old man from Badghis province said that "we should reconcile with the Taliban, because there is no other way to restore peace and security". The inevitability of peace with the Taliban is reflected in most of the interviewees' responses. This point was also reflected in the comment of a 21 year old woman resident of Kabul province: "All these years of fighting with the Taliban had produced no positive results, so why not peace talks".

Among the respondents, there was another group who favored peace talks with the Taliban but at certain conditions (4.9\%). A 45 year old woman from Ghor province said that "bringing peace in this country is difficult. However, it is good if the government can make peace with the Taliban, provided that they do not trample people's rights".

A 36 year old man from Kabul said that "peace with the Taliban is good but it should be in accordance with the Constitutional framework. Not at the cost of rights of people or some ethnic groups or segments of the society". Another woman, 19 year old from Herat, differentiated between Afghan and foreign Taliban, and said: "Afghanistan is home of all Afghans. If the Afghan Taliban accept the constitution and gather under the same banner as other Afghans, then the peace should be made with them". 
There was another group among the respondents. This group is disappointed and believes that the fire of war and insecurity in Afghanistan cannot be extinguished. This group believed that there is no way that the peace with the Taliban could happen (5.5\%). They had their own reasons to support this viewpoint. A 49 years old man from Balkh province, amongst this group, said: "Peace with the Taliban is nothing but deception. If peace was possible, it would have been restor ed in the past 14 years. Given that it has no results till now, it would not have in the future too." Another 24 years woman from Kandahar province considered the foreign intervention as the main factor responsible for failure of peace talks with the Taliban, and said: "Reconciliation with the Taliban is impossible, because the other countries would not let the Taliban to do so."

Another group of respondents opposed the government peace initiative with the Taliban (7.7\%). Due to the widespread insecurity in many parts of Afghanistan, this group also explained their own reasons. For example, a 29 years old woman from Herat province argued, "Personally, I am opposed to peace talks with the Taliban; because they are mercenaries of neighboring countries such as Pakistan. So making peace with the group is no solution." Another 30 year old man from Helmand had an inter esting comment on the issue: "Peace with the Taliban has no meaning. The High Peace Council budget should be given to the Afghanistan's air force". One of the respondents opposed to the government peace with the Taliban, a 33 years old woman from Kunduz province explained her reasons as, "in order to make peace, if it is possible, the Taliban should be banished and expelled from Afghanistan". 


\section{Summary and Conclusion}

Peace and security is an urgent and fundamental need for the stability and progress of any society. Perhaps Afghan people understand it much better than any other nation in the world. Over the past several decades, violence has been the dominant behavior in our society. Now more than ever, people of Afghanistan are in need of peace and stability. Resuming new terms in peace talks between Afghan government with the Taliban, hopes and concerns in this regard have been getting more serious. Bringing peace in most societies is a time-consuming and overwhelming issue. However, the expectations of Afghan people from the government peace talks with the Taliban are clear and precise: peace and security.

In this survey, the attitudes and perceptions of the Afghan people about the government peace talks with the Taliban is studied and analyzed. It was found that the people have serious concerns about the transparency, process, and the content of the talks. Although, they consider peace as a basic necessity but they do not want it to cost. The constitution and achievements of the past 14 years are important for them and in other words, these are redlines which should be strictly observed in the peace process.

Growing insecurity and violence in the country has a clear message. The message is that the efforts made to bring peace had not produced tangible results for the people of Afghanistan. There are serious doubts about the achievements of the High Peace Council which is the official address of the Afghan government for peace negotiations. It is time that our government officials reach a consensus on the issue of peace with the Taliban; otherwise we will be witnessing a repeat of the violence, insecurity, a surge in migration, poverty, unemployment and lack of investment in basic economic sectors of our country. 


\section{Appendixes}

Appendix 1: Questionnaire

Note: Choose only one answer for all the questions!

1. How safe do you feel (physical safety) in your city/village?
1) Very little $\square$
2) little $\square$
3) High $\square$
4) Very High $\square$
5) I do not feel safe $\square$

2. To what extent do you think the role of the people is important in bringing peace?
1) Very little $\square$
2) little $\square$
3) High $\square$
4) Very High
99) I do not know

3. To what extent do you follow the news of the peace talks with the Taliban?
1) Very little $\square$
2) little $\square$
3) High $\square$
4) Very High $\square$
5) I do not care

4. How much do you support the government peace talks with the Taliban?
1) Very little $\square$
2) little $\square$
3) High $\square$
4) Very High
5) I am opposed to the negotiation $\square$

5. What would have been the result of "the government peace talks with the Taliban"?
1) Failed $\square$
2) partly successful $\square$
3) Successful
99) I do not know $\square$

6. In your opinion, how much the National Unity Government can be successful in the peace talks (in percentage)?

7. To what extent do you think the Taliban's actions are acceptable?
1) Very little $\square$
2) little $\square$
3) High $\square$
4) Very High $\square$
5) They are not acceptable $\square$

8. In your opinion, how much the presence of foreign troops can help bringing peace to Afghanistan?
1) Very little $\square$
2) little $\square$
3) High $\square$
4) Very High $\square$
5) It increases the insecurity $\square$

9. In your opinion, how important is the role of women in peacemaking?
1) Very little $\square$
2) little $\square$
3) High $\square$
4) Very High $\square$
5) It is not important $\square$ 
10. What is the impact of the government peace with the Taliban on the status of women?

$\square$ 1) The status of women gets better

$\square 2)$ The status of women gets worse

$\square$ 3) The status of women will not change

$\square$ 4) Other

口99) I do not know

$\square$ 88) No answer

11. What is your main concern about the government peace talks with the Taliban?

$\square$ 1) Ignoring the Constitution

$\square$ 2) Compromising the rights of people

$\square 3$ ) Lack of transparency in peace talks

$\square$ 4) Failing to bring peace

$\square 5)$ Trampling women's rights

$\square 6)$ Other

$\square$ 99) I do not know $\quad \square$ 88) No answer

12. What is the best solution to bring peace and security to Afghanistan?

$\square$ 1) Elimination of the Taliban

$\square$ 2) Direct negotiations with the Taliban

$\square$ 3) Direct negotiations with Pakistan

$\square$ 4) Withdrawal of foreign troops

$\square 5)$ Cooperating with countries in the region to promote peace talks

6) Excluding Pakistan from peace talks

$\square 7$ ) Give a share to the Taliban in the government

$\square$ 8) Other

$\square$ 99) I do not know $\quad \square$ 88) No answer

13. What is the biggest obstacle to peace in Afghanistan?

$\square$ 1) Taliban

$\square$ 2) Local warlords and drug lords

$\square$ 3) Weak administration and widespread corruption

$\square$ 4) Nationalism and tribalism

$\square 5)$ The presence of for eign troops

$\square 6)$ Poverty and illiteracy of the people

$\square$ 7) Other

$\square$ 99) I do not know 88) No answer

14. In your opinion, what is the main reason of the Taliban for fighting the Afghan government?

$\square$ 1) The presence of for eign troops

$\square 2$ ) Widespread corruption in the government 
$\square 3)$ Assuring Pakistan's inter ests

๑4) Power

$\square 5)$ Defending Islam

$\square 6)$ Assuring the interests of the drug lords

$\square 7$ ) Assuring the interests of foreign countries

$\square$ 8) Other

口99) I do not know

$\square$ 88) No answer

15. In your opinion, who benefits from war and insecurity in Afghanistan the most?

$\square$ 1) America and Western countries

$\square$ 2) Pakistan and countries in the region

口3) Corrupt government officials

$\square$ 4) Tribal and jihadi leaders

$\square 5)$ Druglords

$\square 6)$ Other

$\square$ 99) I do not know

$\square$ 88) No answer

16. Why do you think the government peace talks with the Taliban have failed so far?

$\square$ 1) Weakness of the Afghan government

$\square$ 2) Not including people in peace talks

$\square$ 3) The involvement of neighboring and regional countries

$\square$ 4) The interfer ence of America and the West

$\square 5)$ Negotiating with the Taliban members who are not qualified

$\square 6)$ Other

$\square$ 99) I do not know

$\square$ 88) No answer

17. In your opinion, what is the appropriate title for naming the Taliban?
1) Dissatisfied brothers $\square$
2) Political opponents $\square$
3) Mujahidin
4) Insurgents $\square$
5) Enemy $\square$
6) Mercenaries
7) Terrorists $\square$
99) I do not know

88) No answer

18. In your opinion, what is the main defect of the High Peace Council in promoting negotiations?

$\square$ 1) Lack of public support

$\square 2)$ Representing mostly a particular ethnic group

$\square$ 3) The ignorance of its members about the negotiation procedure 
$\square$ 4) The Council does not have the necessary competence and independence

$\square 5$ ) It is a symbolic Council

$\square 6)$ The existence of corruption in the council

$\square 7)$ Taliban's influence in the High Peace Council

$\square 8$ ) Foreign interference in the matters of the Council

$\square$ 9) Other

口99) I do not know

$\square$ 88) No answer

19. To what extent are you optimistic about the High Peace Council success in promoting the peace talks?
1) Very little
2) little $\square$
3) $\square$ High
4) Very high $\square$
5) Not hopeful $\square$

20. Have the programs for absorbing the armed opposition in peace process in your province been successful?
1) Yes $\square$
2) No $\square$
99) I do not know

21. In the following table, specify the score of your agreement or disagreement with each statement!

\begin{tabular}{|c|c|c|c|c|c|c|c|}
\hline \multicolumn{2}{|r|}{$\begin{array}{l}\text { Use }(\sqrt{ }) \text { to indicate your answer! } \\
\text { Note: Read the sentences carefully! }\end{array}$} & \multirow{2}{*}{ 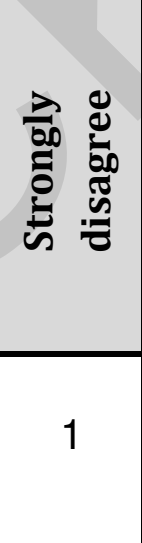 } & \multirow{2}{*}{ 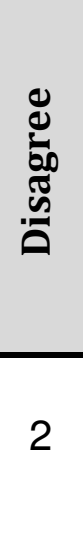 } & \multirow{2}{*}{ 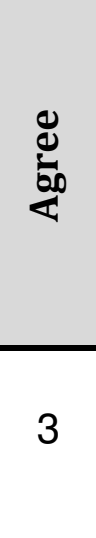 } & \multirow{2}{*}{ 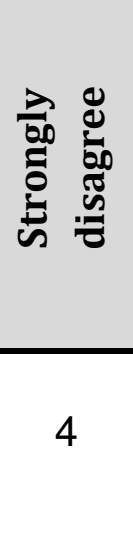 } & \multirow{2}{*}{ 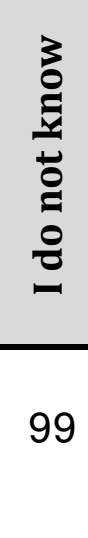 } & \multirow{2}{*}{ 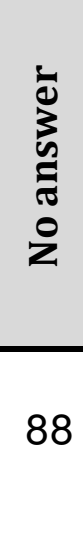 } \\
\hline 1 & $\begin{array}{c}\text { Government officials do not have } \\
\text { consensus on peace with the } \\
\text { Taliban. }\end{array}$ & & & & & & \\
\hline 2 & $\begin{array}{l}\text { Peace with the Taliban is } \\
\text { impossible. }\end{array}$ & 1 & 2 & 3 & 4 & 99 & 88 \\
\hline 3 & $\begin{array}{l}\text { The Afghan government cannot } \\
\text { promote peace talks without } \\
\text { Pakistan cooperation. }\end{array}$ & 1 & 2 & 3 & 4 & 99 & 88 \\
\hline 4 & $\begin{array}{l}\text { Taliban are part of Afghan society } \\
\text { and it is important to share power. }\end{array}$ & 1 & 2 & 3 & 4 & 99 & 88 \\
\hline 5 & $\begin{array}{c}\text { The best way to achieve peace and } \\
\text { security is to fight the Taliban. }\end{array}$ & 1 & 2 & 3 & 4 & 99 & 88 \\
\hline 6 & $\begin{array}{c}\text { Women's rights are not important } \\
\text { in the way to achieve peace. }\end{array}$ & 1 & 2 & 3 & 4 & 99 & 88 \\
\hline
\end{tabular}


22. Score each one of the following institutions and group for their effect in the success of peace talks from 1 to 5 points!

( 1 = lowest score, 5 = highest score $)$

\begin{tabular}{|c|c|c|c|c|c|c|c|c|}
\hline \multicolumn{2}{|c|}{ Items } & \multicolumn{5}{c|}{ Score } & $\begin{array}{c}\text { I do not } \\
\text { know }\end{array}$ & $\begin{array}{c}\text { No } \\
\text { answer }\end{array}$ \\
\hline 1 & High Peace Council & 1 & 2 & 3 & 4 & 5 & 99 & 88 \\
\hline 2 & Political parties & 1 & 2 & 3 & 4 & 5 & 99 & 88 \\
\hline 3 & Ihadi and tribal leaders & 1 & 2 & 3 & 4 & 5 & 99 & 88 \\
\hline 4 & Civil society activists & 1 & 2 & 3 & 4 & 5 & 99 & 88 \\
\hline 5 & Afghanistan Ulema Council & 1 & 2 & 3 & 4 & 5 & 99 & 88 \\
\hline 6 & Loya Jirga & 1 & 2 & 3 & 4 & 5 & 99 & 88 \\
\hline 7 & Parliament & 1 & 2 & 3 & 4 & 5 & 99 & 88 \\
\hline 8 & $\begin{array}{c}\text { Mass media (TV, radio, } \\
\text { new spapers, etc) }\end{array}$ & 1 & 2 & 3 & 4 & 5 & 99 & 88 \\
\hline
\end{tabular}

23. Score each one of the following countries to the success of peace talks from 1 to 5 points!

\begin{tabular}{|c|l|c|c|c|c|c|c|c|}
\hline \multicolumn{2}{|c|}{ Items } & \multicolumn{5}{c|}{ Score } & $\begin{array}{c}\text { I do not } \\
\text { know }\end{array}$ & $\begin{array}{c}\text { No } \\
\text { answer }\end{array}$ \\
\hline 1 & America and its Western allies & 1 & 2 & 3 & 4 & 5 & 99 & 88 \\
\hline 2 & India & 1 & 2 & 3 & 4 & 5 & 99 & 88 \\
\hline 3 & Pakistan & 1 & 2 & 3 & 4 & 5 & 99 & 88 \\
\hline 4 & China & 1 & 2 & 3 & 4 & 5 & 99 & 88 \\
\hline 5 & Iran & 1 & 2 & 3 & 4 & 5 & 99 & 88 \\
\hline 6 & Russia & 1 & 2 & 3 & 4 & 5 & 99 & 88 \\
\hline 7 & Saudi Arabia & 1 & 2 & 3 & 4 & 5 & 99 & 88 \\
\hline 8 & Turkey & 1 & 2 & 3 & 4 & 5 & 99 & 88 \\
\hline 10 & Qatar & 1 & 2 & 3 & 4 & 5 & 99 & 88 \\
\hline
\end{tabular}




\section{General information}

The place of interview:

Date of interview :

Interviewer name:

Questionnaire number:

1. Age:

2. Gender:

1) Female $\square$

2) Malea

3. Ethnicity:
1) Pashtun $\square$
2) Tajik $\square$
4) Uzbek $\square$
5) Other

3) Hazara $\square$

4. Marital status:
1) Single $\square$
2) Married $\square$
3) Widow $\square$
4) Divorced $\square$

5. Current location:
1) Province:
2) Districts:
6. Place of living:
1) City $\square$
2) Village $\square$

7. Education:
1) Illiter ate or bar ely educated $\square$
2) Primary school graduate $\square$
3) Secondary school graduate
4) High school graduate $\square$
5) University students, Associated degree, Bachelor $\square$
6) Master and higher $\square$
7) Seminary educated $\square$

8. Occupation:
1) Unemployed $\square$
2) Homemaker $\square$
3) Government employee $\square$
4) private sector employee $\square$
5) self-employed $\square$
6) Students $\square$
7) student or teacher of religious school, preacher $\square$
8) Other

9. Monthly mean income:
1) Not Income
2) Bellow 2000 Afghanis $\square$
2) 2000 to 3000 Afghanis $\square$
3) 3001 to 5000 Afghanis $\square$
4) 5001 to 10000 Afghanis $\square$
5) 10001 to 20000 Afghanis $\square$
6) 20001 to 30000 Afghanis $\square$
7) more than 30000 Afghanis $\square$

10. In general, what are your reasons to agree or disagree with the government peace talks with the Taliban? 


\section{Appendix 2: Authors' introduction}

Ghulam Reza Ebrahimi (Researcher at AISS): Mr. Ebrahimi holds bachelor's degree in sociology (field of research) and a master degree in urban planning. He completed his studies in Ir an and during his studies has contributed in several major research projects. He has defended his thesis on "Analysis of sense of place between Afghan refugee residents in Mashhad" with a high grade. Mr. Ebrahimi worked as the editor of the daily "Sadaye Shahrwand", before joining the Afghan Institute of Strategic Studies. Prior to this study, he has contributed to the survey "Corruption mapping in Afghanistan" with this institute which was conducted in 12 provinces.

Hussain Ali Karimi (Researcher at AISS): He has a master degree in urban planning and completed his studies in Iran. During his studies he has contributed in two major research projects of Tehran University entitled "Second generation of Afghan refugees in Iran (1389)" and "Social adaptation and family changes among Afghan refugees in Iran (1390)". He has been a lecturer at Istiqlal University in Kabul, before he joined the AISS. Prior to this study, he has contributed to the survey "Corruption mapping in Afghanistan" with this institute which was conducted in 12 provinces. 


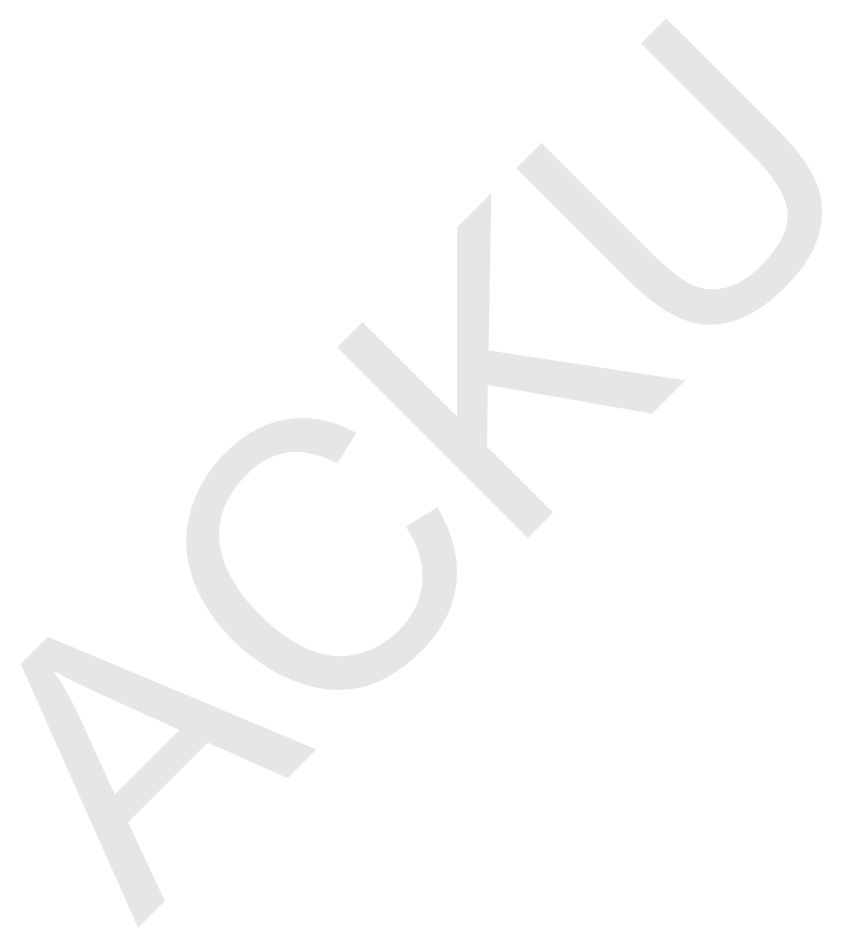




\section{CONTACT}

Afghan Institute for Strategic Studies (AISS)

Former Turquoise Mountain Fort | Post Box No: 5214 | Karte-Parwan | Kabul | Afghanistan

Ghulam Reza Ebrahimi

Researcher, Department of Peace Studies

E: ebrahimi@aiss.af

Hussain Ali Karimi

Researcher, Department of Peace Studies

E:karimi@aiss.af

www.aiss.af | contact@aiss.af | Facebook: facebook.com/ Afghaninstitueforstrategicstudies/

Twitter: @aissofficialpag | LinkedIn: Afghan Institute for Strategic Studies

Commercial use of all publications by the AISS is not permitted without the written consent of the AISS.

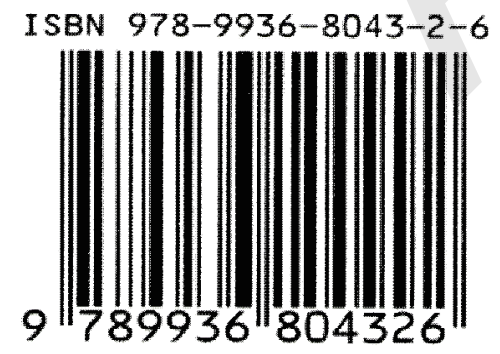

The analysis provided in this report are those of the research team and do not reflect the official position of Afghan Institute for Strategic Studies (AISS) or National Endow ment for Democracy (NED). 